\title{
BOLETIM XLIV
}

\section{MINERALOGIA}

N. 6

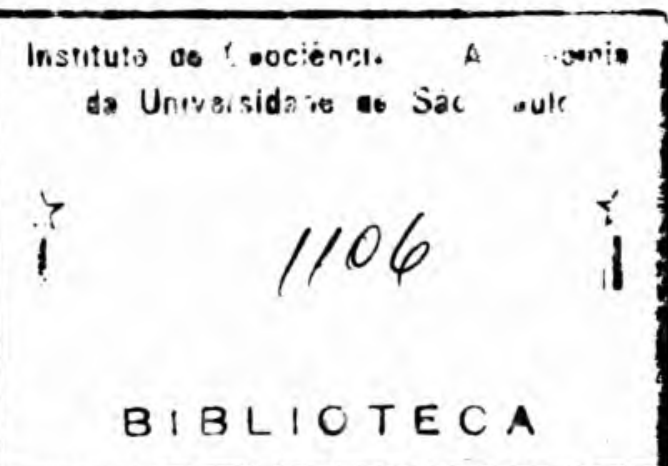



Instituto de Geociências

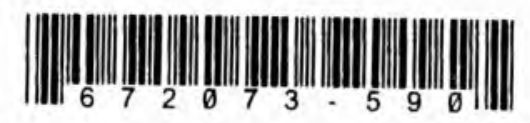

Boletins da Faculdade de Filosofia, Ciências e Letras da Universidade de São Paulo

no.6-10(1944-46, 1952)

\section{S. PAULO - BRASIL}


Os Boletins da Faculdade de Filosofia, Ciências e Letras da Universidade de São Paulo são editados pelos Departamentos das suas diversas secções. Toda correspondência deverå ser dirigida para - Departamento respectivo da Faculdade de Filosofia, Ciências e Letras - Caixa Postal 105-B, S. Paulo, Brasil.

The "Boletins da Faculdade de Filosofia, Ciências e Letras da Universidade de S. Paulo" are edited by the different departments of the Faculty.

All correspondence should be addressed to the Department concerned, Caixa Postal 105-B, São Paulo, Brasil.

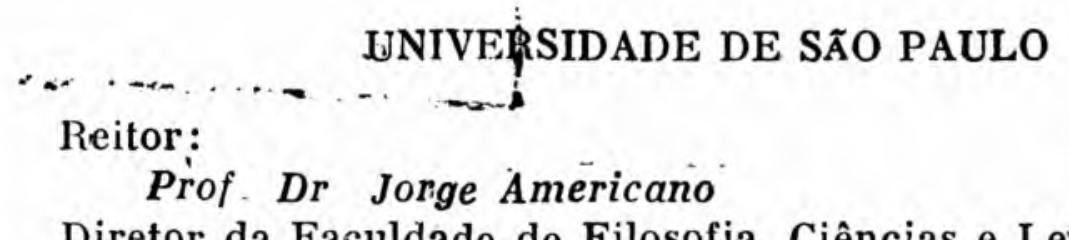

Diretor da Faculdade de Filosofia, Ciências e Letras: Prof. Dr André Dreyfus

Cadeira de Mineralogia e Petrografia:

Professor:

Eng. ${ }^{\circ}$ Reynaldo Saldanha

Professor interino:

Dr Ruy Ribeiro Franco

Assistentes :

Dr. William G. R. Camargo

Lic. ${ }^{\circ}$ Waller Loewenstcin

Estagiário:

Licenciando José M. V Coutinho 


\section{MINERALOGIA N. ${ }^{\circ} 6$}

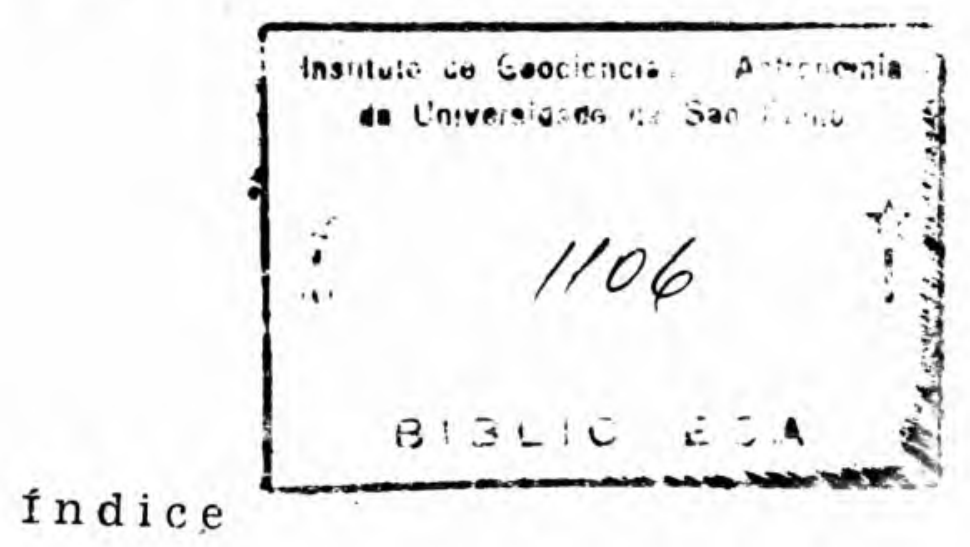

Franco, R. R. - A faixa estanifera do Rio Grande do Sul

S. Paulo - Brasil

1944 
550.5 M664 ma

$1944-1952$

V. 3

$n \cdot 6-10$ 


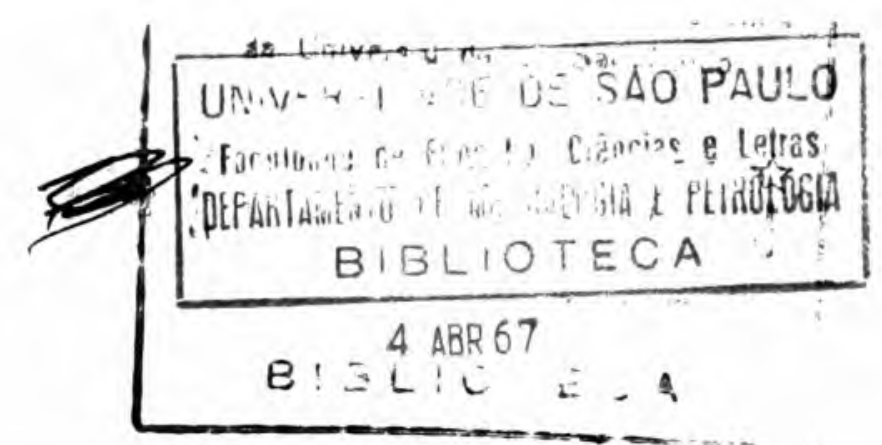

\title{
A FAIXA ESTANIFERA DO RIO GRANDE DO SUL
}

\author{
por \\ INDICE \\ Ruy Ribeiro Franco
}

Pág.

1 Introdução $\quad \ldots \quad$.

2. Descrição da área mineralizada 5

3 . Breve histórico e exploração 10

1. Geologia geral da região 12

5. Descrição das rochas da região $\quad$.. $\quad 13$

a. Algonquiano 13

b. Devoniano (?) 2?

6. Nineralogênese $\quad$.. 21

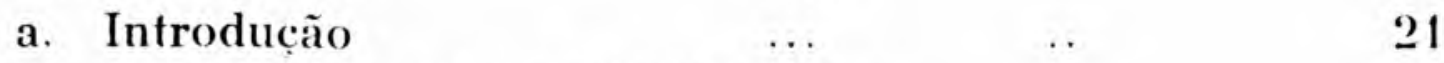

b. Turmalinizacão e greisenficação 28

c. Cassiterita $\quad$.. 36

d. Aplitos e pegmatitos 37

e. Filões $\quad \ldots \quad 43$

7 Conclusões

8. Summary and Conclusion: 51

9. Bibliografia $\quad \ldots \quad 52$ 



\section{A FAIXA FSTANífERA Do RIO GRANDE DO SUL}

\section{Introdução}

Este trabalho apresenta os resultados de investigaçóes geulógicas, petrográficas e mineralógicas da já conhecida área mineralizada, a "Paixa estanifera do Rio Grande do Sul"

Esta faixa, relativamente rica de minas, jazidas e ocorrências de cassiterita, está situada nos municipios de Encruzilhada e Piratini. Compreende duas partes bem distintas - a do norte, onde estão localizadas as minas de Cerro d'Arvore e Sanga Negra e a do sul que conla com as minas e jazidas do Taboleiro, Cerro Branco, Campinas, Santa Bárbara, Estreito. Pedro Freitas, Aluvião Camaquan e outras ocorrências de valor secundário. As duas zonas compreenciem, não somente depósitos filonianos, pegmatíticos e eluvionais, mas tambem depósitos aluvionais, que mostram sempre algutm interêsse cconònico.

Neste trabalho, trataremos somente dos depósitos situados na parte sul da faixa estanifera deixando de lado a parte norte, onde além de cassiterita existem volframila, calcopirita, arsenopirita. turmalina, fluorita, hematita especular e outros minerais que ocorrem em veeiros de quartzo de espessura variável e em extensão aproximada de 1 quilómetro, em diferentes afloramentos (Cerro d'irvore).

Está tese, realizada por sugestão dos professores Reynaldo Saldanha da Ciama e Viktor Leinz, teve seu inicio em Janeiro de 19.13, quandio o autor colheu os dados geológicos e as amostras representativas das formaçóes, para os estudos petrográficos e petrogenéticos.

\section{Descriçio da área mineralizada}

A maior parte da área mineralizada compreende dois tipos principais de rochas. O mais antigo é constituido de micaxistos, cloritaxistos. Lalcoxistos, filitos, yuartzitos e mimores, colocados no a!gonquiano inferior (série Porongos).

Fsta série, provàvelmente metamorfizada e dobrada durante o periodo algonquiano, foi invadida por grandes massas magmá- 
ticas ácidas, consistindo de granitos ligeiramente alcalinos e diques de apiitos, pegmatitos e veeiros de quartzo, mineralizados em Sno.: e MoS. (êste último menos comum), como constituintes primários do magma. Essas intrusões constituem o segundo tipo de rochas. Targa (34), que estudou parte da área mineralizada, conclue que a mineralização não se processou por influência de intrusivas graniticas, mas sim de rochas dioríticas, encaixadas nos xistos cristalinos. Esse Autor considera ainda que as regiōes do planalto, isto é, as partes mais elevadas e tamiém mais denudadas. sejam constituidas de gnais-granitos.

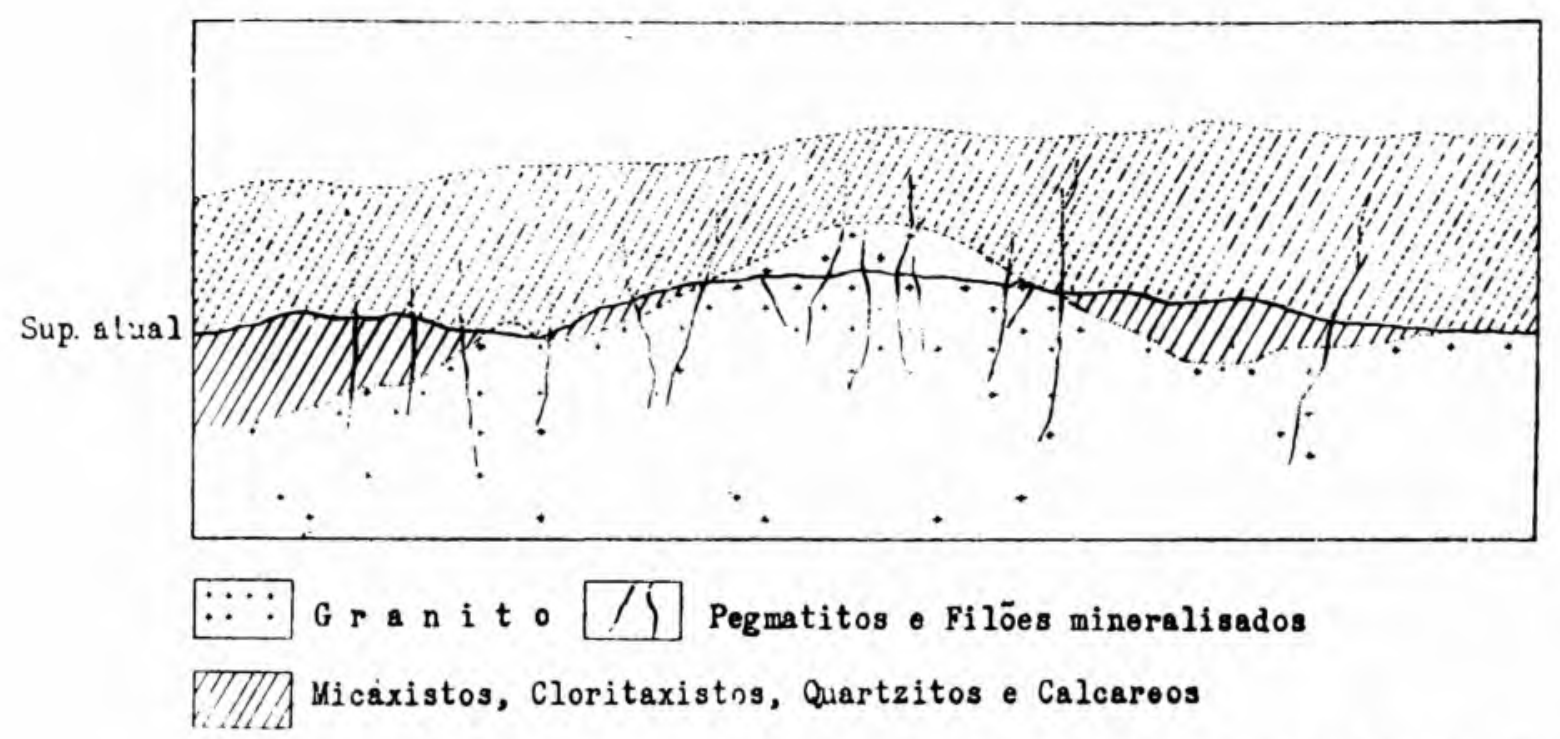

Fig. 1 Esboço mostrando as aparentes relações dos diques de pegmatito e filōes mineralizados com o granito e os termos metamórficos da série Porongos.

De todos os trabalhos já publicados sobre a região, êste é o que trata mais pormenorizadamente de perfís geológicos e das diferentes relaçóes entre os corpos mineralizados e as rochas locais. Este Autor, contudo, não dedicou muita atençáo aos estudos petrográficos das rochas da região.

As intrusões graniticas, que provocaram em algumas regiões a formação de auréolas cornubianíticas nos termos da série Porongos (esta série é conhecida também pelos nomes de Ibaré, São (iabriel, etc.), pertencem ainda ao algonquiano, sendo entretanto mais recent $\epsilon$ que êstes. A região estanifera localiza-se, principalmente, na zona de contacto entre os xistos e o granito, ocorrendo os corpos mineralizados tanto numa como noutra formação (ver mapa geológíco anéxo).

Xistos e granitos sofreram, no decorrer da fase de mineralização, bem acentuado metamorfismo pneumatolítico exógeno e endógeno, devido à ação, em alta temperatura, de emanações aquo-boro-flluoriferas residuárias. Resultou dêste metamorfismo a 
turmalinização dos xistos, quartzitos e mesmo dos granitos, com " formação, em algumas regiões, de verdadeiro "schorl-rock" (agregado de turmalina e quart\%o). Resultou também, embora mais raramente, a formação de "greisen" (Campinas), onde se pode notar intensa muscovitizacào das paredes do granito encaixante e larga disseminação de cristais de cassiterita e turmalina.



Fig. 2 - Mina Campinas, mun. de Encruzilhada. Trincheira aberta no granito alterado, rico de faixas greisenficadas e com disseminação de cassiterita.

Campinas, uma das principais minas da região e a que tem sido mais trabalhada, apresenta-se com características de depósito tipo "stock-wcrk" com predominância de fendas nas direções N3OE, YHilV e NS.

A região, até o presente momento, não foi ainda bem estulada, bastando dizer que os mapas existentes sobre a área são incompletos e muito pouco precisos, assim geológica como topogràficamente.

E' servida exclusivamente por estradas de rodagem precárias, Iransitáveis, não obstante. mesmo durante as estacões chuvosas. As estações ferroviárias mais próximas são as de Cachoeira e Rio Pardo ao norte e Pelotas, ao sul. As distâncias destas cidades variam respectivamente de 120,150 e 170 quilómetros, em média, para as diversas jazidas.

Com diferenças de niveis em média de 100 a $150 \mathrm{~m}$, a região se mostra, topogràficamente, acidentada. Aparecem, em quase toda a área, inúmeras elevações mais ou menos conspicuas, onde se encontram estruturas remanescentes de antiga superfície gliptogenética de erosão. Em Coxilha das Figueiras e áreas circunvizinhas, o granito, já completamente denudado e rico de matacões, aparece sob a forma de grande batolito. Em Campinas e Cordi- 
lheira do Estreito, a erosão está pondo a descoberto os pontos de contacto entre o granito intrusivo e os xistos encaixantes. Partece evidente que, a área onde se localizam as jazidas, experimeutou

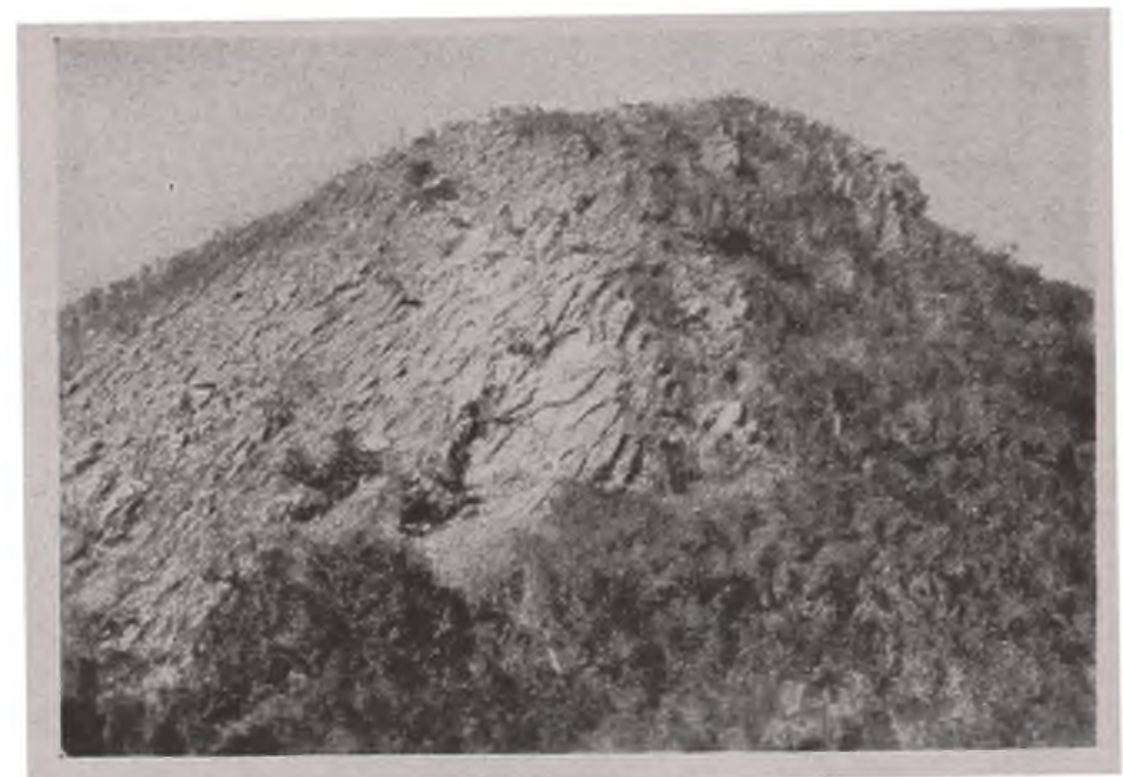

Fig. 3 - Mina Campinas, mun. de Encruzilhada. Micaxistos com lentes de quartzito.

longo processo de desintegracão, através de sucessivos ciclos. Extensas áreas estâo cobertas por formacão relativamente espessa de seixos rolados e angulosos de tamanhos variados, provenientes

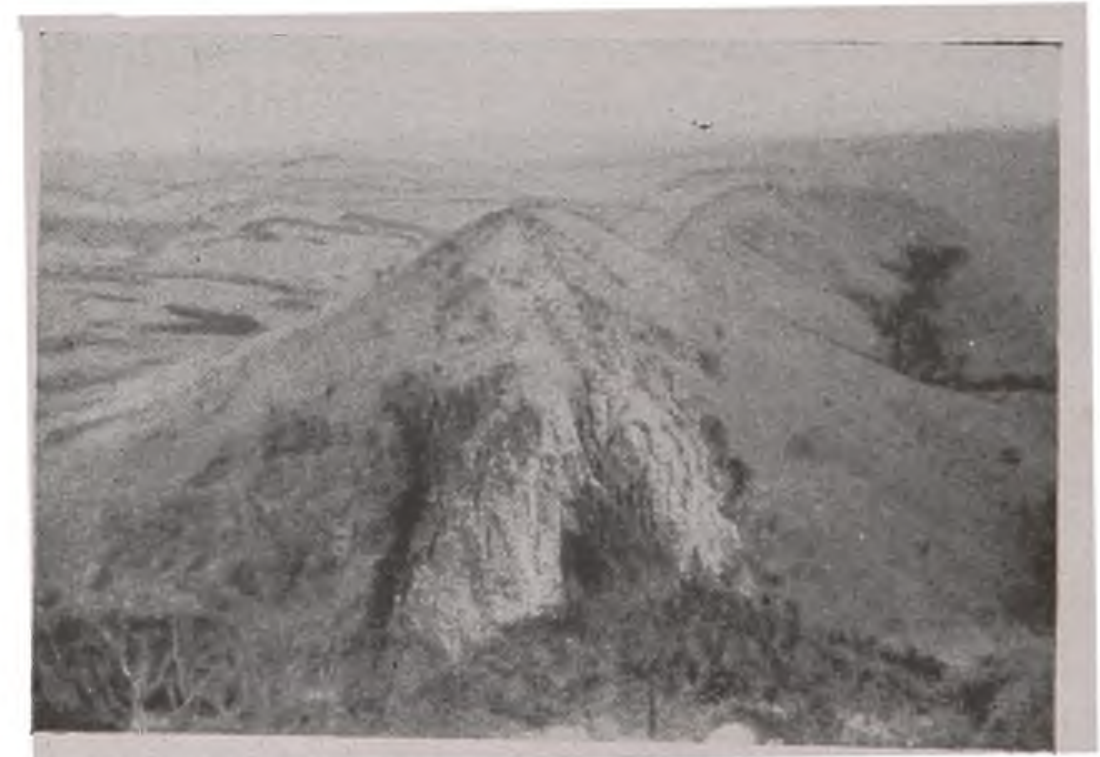

Fig. 4 - Paredäo, mun. de Piratini. Monadnock de quartzito. Ao fundo, granito.

da fragmentação mecônica dos quartzitos e dos inúmeros filões de quarlzo, estéreis ou não. Nessas áreas, bem como naquelas onde predominam quartzitos e xistos, a vegetação é muito pobre. 
Matas densas ocorrem sòmente nas áreas graníticas, onde há sempre camada de terra vegetal relativamente espessa (baixadas). Os "hogbacks" de quartzito e quartzito-xistos do Paredão, Cerro Branco, Cerro do Portão e Campinas e outros menos cons-

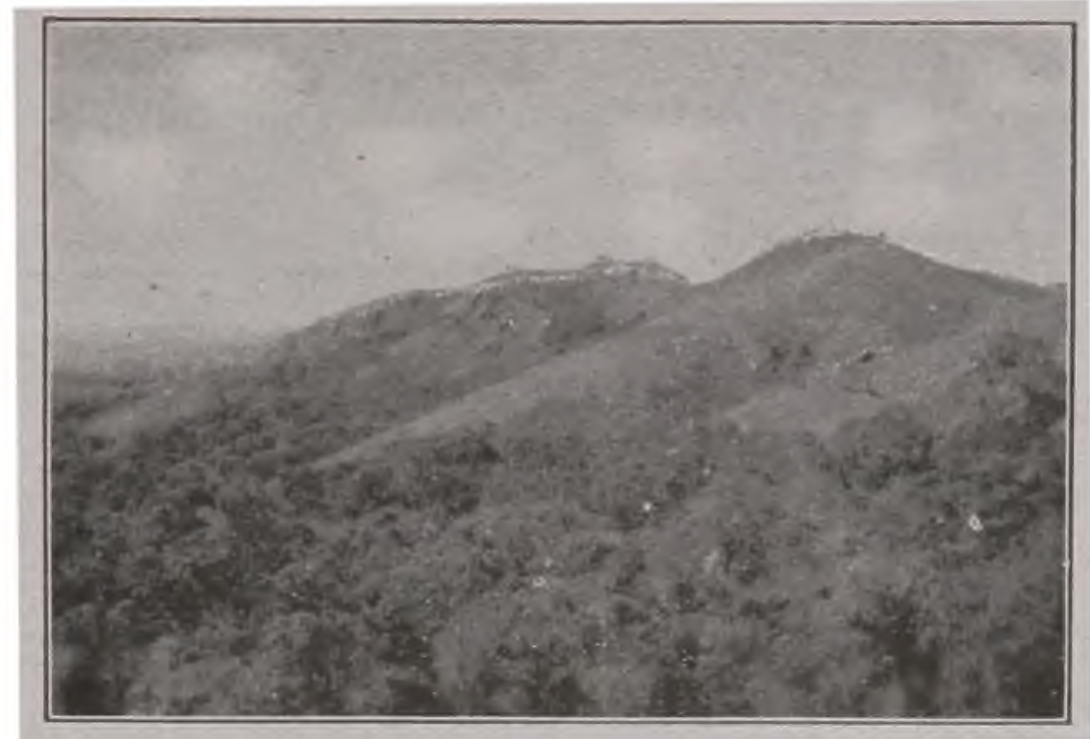

Fig. 5 - Cerro do Poitc̃o, mun. de Encruzilhada. Xistos e quartzitos. No primeiro plano a vegetação das baixadas.

pícuos, com mergulhos geralmente uniformes, constituem também proves evidente do processo erosivo sofrido pela áre. mineralizada.

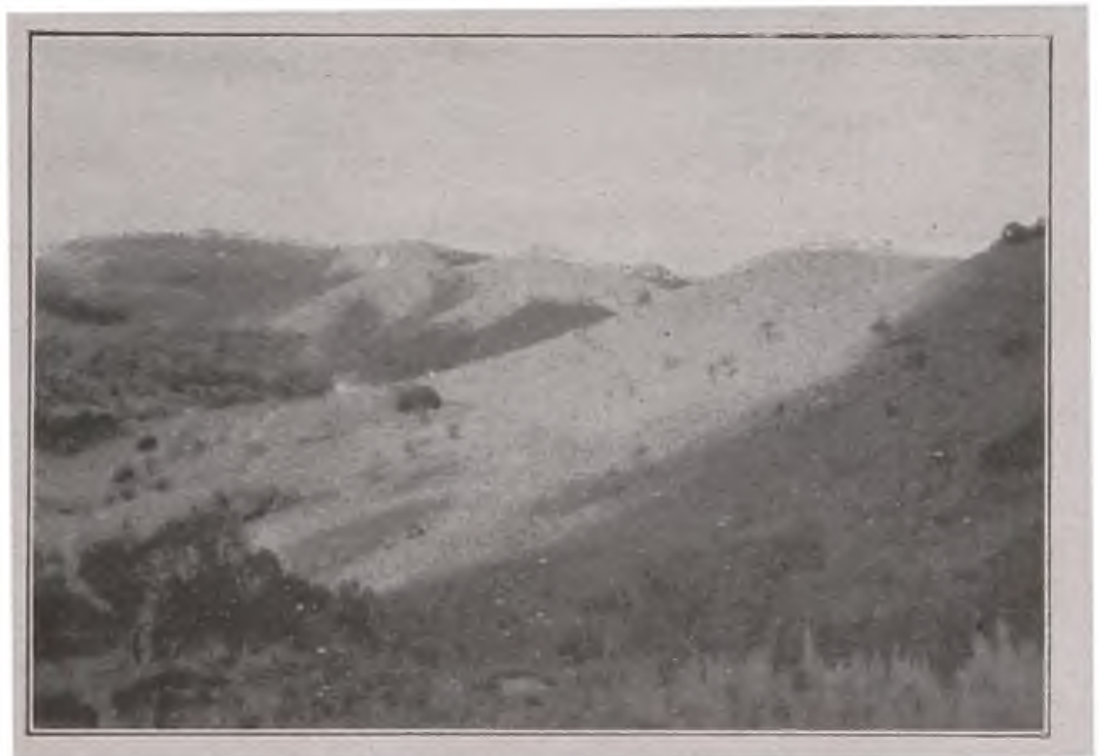

Fig. 6 - Cordiiheira do Estreito, municípios de Linciuzilhada e Piratini - Xistos e quartzitos.

Quaisquer que tenham sido os esforcos determinantes da aberlura das diáclases e fendas, estas se deram principalmente na di- 
reção N3OE com formacão de inumeros diques e filões aproximadamente paralelos. Há, contudo, bom número dêstes que não seguem èste rumo geral, mas sim outras direcões, N45W e NS que correspondem, visivelmente. às outras diáclases dos granitos e $\mathrm{xistos}$.

O verdadeiro mecanismo da intrusão, sua relação com as fendas e o processo da mineralização pròpriamente dito, serão tratados em capitulos que se seguem.

No estudo que faremos sobre a formação dos diques aplíticos, pegmatílicos e dos filóes mineralizados e demais fenomenos que se realizaram simultâneamente, analisaremos, em separado.

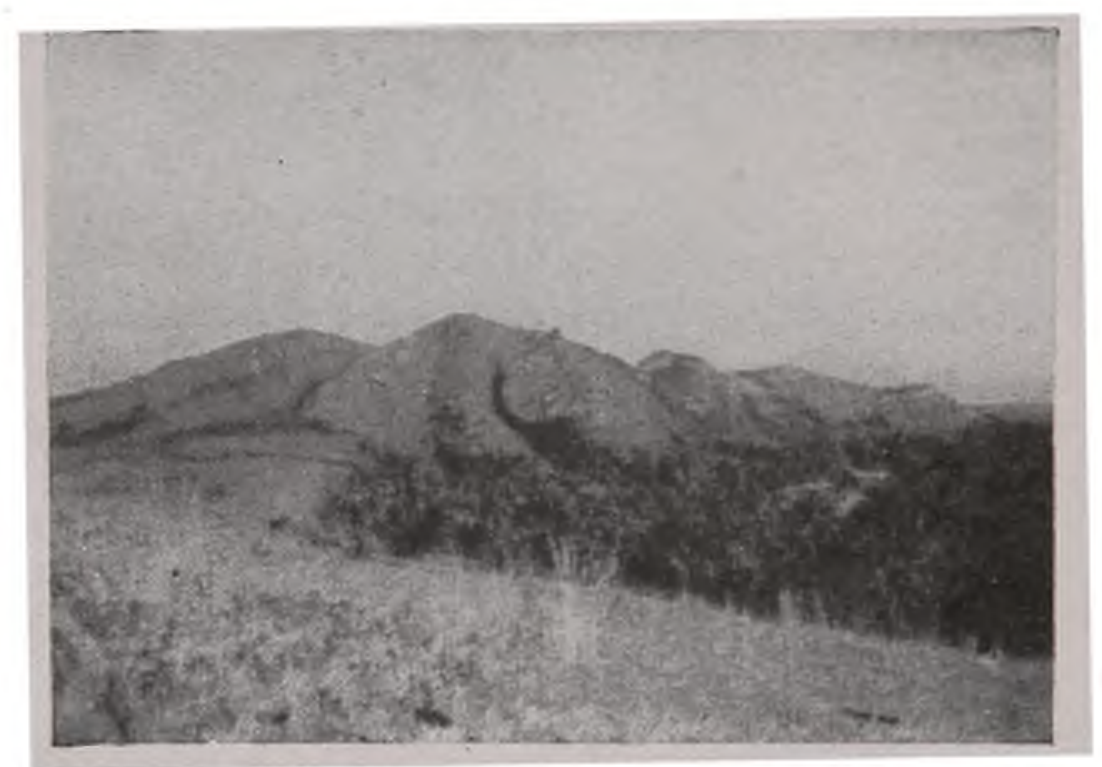

Fig. 7 - Cerro do Inferno, municipio de Piratini - Qua:tzite lenhoso. INo primeiro plano aparecem o granito e a mata ciliar do Rio Camaquan.

os diversos fatos, procurando não perder a noçăo de conjunto tanto no espaço como no tempo.

\section{Breve histórico e exploração}

As primeiras amostras de cassiterita da faixa estanifera, foram descobertas e identificadas por Frederico Gustavo Scheffer. por volta de 1903, na região de Campinas, época na qual já funcionava a mina de Cerro d'Arvore na extracão de volframita. Entretanto, sòmente no ano de 1913 é que se iniciaram os primeiros trabalhos de extração de cassiterita d'esta região pela Cia. Belga de Estanho de Campinas Sociedade Anónima, fundada pelo seu descobridor. Foram construidos, engenho completo para tratamento de $250 \mathrm{ton} / 24 \mathrm{~h}$ de minério, cabo aéreo de 1.100 metros e plano 
inclinado para o transporte do elúvio do vale da sanga da Bateia até a estaçào do cabo aéreo.

Em 1911, a mina entrava em franca produção para alguns mezes depois cessar completamente seu funcionamento en conseqüência da Guerra Mundial de 1914. Ficaram assim isoladas, a Diretoria em Bruxelas e a Administraçáo da mina em Campinas.

Atualmente esta mina vem sendo explorada superficialmente por garimpeiros e faiscadores por conta do proprietário e concessionário.

A instalação da Cia. Belga no ano 1913, seguiram-se a descoberta de outros afloramentos como sejam aqueles de Cerro Branco e 'Taboleiro, pertencentes desde 1928, à Sociedade de Mineração Renner l.tda. Surgiram logo depeis as excuvacões dos afloramentos da mina Paulista, Santa Bárbara, Gorita e mais recentemente Pedro Freitas.

Ainda, com referéncia a êsle breve histórico da região, faça-se aqui ligeira menção sobre o depósito conhecido pelo nome de Aluvião Camaquan, situado na maior curva do rio do mesmo nome. Este, de propriedade da Sociedade Mendes Teixeira e Cia. de Pelotas é constituido de formações sedimentares de diversas épocas, actumuladas na margem esquerda do rio Camaquan. A camada aluvionar contendo cassiterita acha-se no fundo das formações sedimentares acima mencionadas, numa profundidade média de 12 metros. F' constituida principalmente de cascalhos. nos quais a cassiterita, geralmente granular e de tamanho variado, se acha associada ̇̀ granada, ilmenita, monazita, turmalina, magnctita, hematita, zirconita e muito raramente, a pequeninas pepitas de ouro. Estes depósitos aluvionais foram recentemente prospectados pela Cia. de Estradas de Ferro e Minas de São Jerônimo, visando confirmar a prospeccão do engenheiro Anatol Bromirsky, que também pertenceu a essa Cia. Segundo êste último. em trabalho reslizado nos anos 1928-29, a reserva de cassiterita prospectada nos antigos leitos do rio Camaquan seria de mil toneladas.

Antigamente e ainda hoje grande parte da cassiterita que se funde na região (fusão feita em fornos revérberos) provém principalmente de depósitos eluvionais e aluvionais encontrados nas depressões das sangas e nas encostas das rochas que sofreram a mineralização.

Os trabalhos até agora realizados teem sido conduzidos de maneira extremamente rudimentar. Nos depósitos aluvionais e eluvionais a extracĩo tem visado somente as concentrações ricas de cassiterita, cujo beneficiamento, com bateias manuais, acarreta grande perda do material fino durante a lavagem. Nos filozes, garimpeiros e faiscadores, Irabalhando somente no material menos coerente ou muito rico de cassiterita, desprezam por completo o 
mincrio que se acha associarlo a alguma ganga quartzosa ou feldspática não alterada. Do emprego de tão primitivos métodos de trabalho e da falta de orientação técnica, resulta o empobrecimento das jazidas no sell conjunto, com sesis graves inconvenientes.

Das jazidas e ocorrências, algumas se acham quase que toralmente intactas e outras parcialmente trabalhadas, não existindo. em toda a região, jazida alguma, (com exceção de Campinas e Aluvião Cimaquan) que tenha sido prospectada adequadamente.

Somos, contudo, de opinião que a área é bem promissora e deve merecer do governo e das pessoas interessadas na metalurgia do estanho, estudo de prospecção minucioso e pormenorizado.

Pelo scu interêsse econòmico, mineralógico e geológico, a região, objeto dèste trabalho, já foi estudada sob diversos pontos de vista, devendo-se salientar os trabalhos de P F Carvalho (10), D. Guimarães (17), F Targa (34), V Leinz e S. A. Carneiro (25). 0. Barbosa (2) e P. A. Alvim (1). Merecem ser citados ainda alguns outros trabalhos que foram consullados para confronto do estudo geolrigico da região mineralizada e outros pontos do Estado do Rio Grande do Sul -- E. A. Teixeira (35), V Leinz e E. A. Teixcira (2), $Y^{r}$ Leinz (23), I Leinz, A. Barbosa e E. A. Tejxeira (24), D. Cuimarães (18) e A. I. de Oliveira e O. Henry Leonardos (29)

\section{Geologia geral da região}

A geologia geral da região já se encontra delineada em alguns trabalhos anteriores. Entretanto, para melhor compreensão das relaçóes entre os termos da série Porongos, as intrusivas ácidas e as jazidas, levantámos o mapa geológico anexo. Os perfís. figs. 8 e 9, inostram as relações existentes entre os xislos e o granito, principais formações geológicas da região.

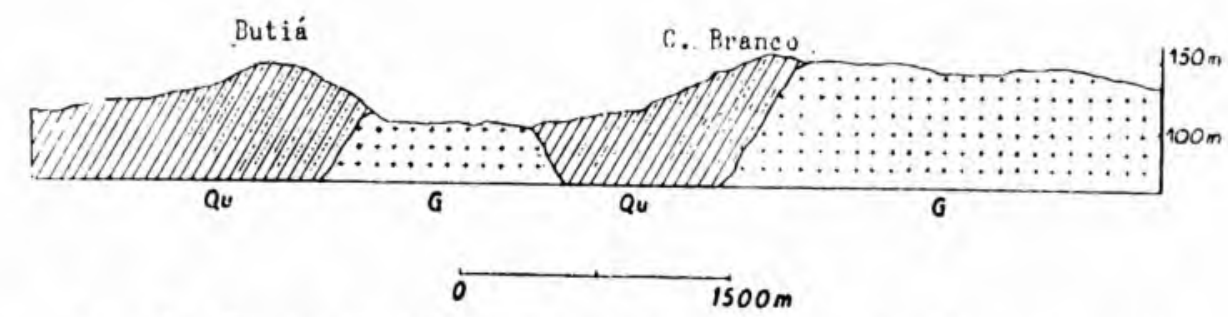

Fig. 8 - Seç̧ão EW, municipio de Encruzilhada, Qu quartzitos e xistos, G granito.

A área estudada compreende xistos da série Porongos, granitos do mesmo periodo e ao norte, na região do Taboleiro, assentam sobrc os primeiros, os sedimentos da série Camaquan (devoniano?). (iranites e xistos constituem o complexo cristalino, substrato para as formações de idtades mais recentes. Em toda 
área percorrida pelo aulor não foi encontrado un ponto siquer, no qual se pudessem notar os contactos entre o complexo cristalino (arqueano) e a base da série Porongos (algonquiano inferior).

A intrisão granitica é posterior à formacioo dos xistos, mármores e quartzitos por haver indicios de metamorfismo térmico no conlacto de uma e outra formaça. Há lambém inúmeras apófises de granito nos xistos.



Fig. 9 Secção EW, municipio de Piratiní, Qu quartzitos e xistos, G granito.

Como coluna geologica, adolaremos os dados de Leinz, Barbosa e Teixeira (2a) para a área Cacapava-Iavras. Alguns dos termos estratigráíicos citados por êstes Autores foram por nós encontrados na região da faixa estanifera. Assim, seguindo a ordem cronológica dêsses Aulores, teriamos a coluna geológica da área estudada, disposta segundo o quadro que se segue. Muitas formacões encontradas em áreas circunvizinhas à da faixa estanifera não foram observadas pelo autor. Finalmente, não cogitaremos acui da questão das iriarles destas e de oulras formaçóes, porquanto nos faltam dados seguros a respeito.

\section{Descricuão das rochas da região}

No estudo petrogiáfico da regiào mineralizada. trataremos principalmente de très formações - xistos e quartzitos; granitos intrusioos e arenitos arcosianos da série Camaquan.

\section{a) Algonquiano}

Os xistos incluidos neste periodo apresentam-se com todos os caracteristicos dos termos homólogos de outras sćries do mesmo periodo --- série Minas, série São Roque, sćrie Assunguí, etc.. onde se nola quase idèntico gráo de metamorfismo. A série Porongos, na região mineralizada, não mostra os calcáreos proterozóicos que se achan intercalados nos xistos das regióes circunvizinha:. Os xistos predominantes apresentam-se de granulação fina. tendendo para filitos nos quais se pode distinguir textura cristalina visível a olho nú. As superfícies de xistosidade 


\section{(IUADRO}

Coluna geológica da área mineralizada

\begin{tabular}{|c|c|}
\hline \multirow[t]{2}{*}{$\begin{array}{l}\text { Post-devoniano } \\
\text { (não observado) }\end{array}$} & $\begin{array}{l}\text { Vulcanismo andesítico - Mineralização cuprifera } \\
\text { aurifera. }\end{array}$ \\
\hline & Discordância \\
\hline \multirow[t]{2}{*}{ Devoniano? } & $\begin{array}{l}\text { Série Camaquan - Arenitos vermelhos e conglo- } \\
\text { meratos de mais de } 500 \text { metros de espessura e par- } \\
\text { cialmente perturbados pela intrusão dos andesitos. } \\
\text { Arenitos arcosianos. }\end{array}$ \\
\hline & Discordância \\
\hline $\begin{array}{l}\text { Siluriano? } \\
\text { (não observado) }\end{array}$ & Vulcanismo ácido com quartzo-pórfiro e felsito. \\
\hline \multirow[t]{2}{*}{$\begin{array}{l}\text { Siluriano? } \\
\text { (não observado) }\end{array}$} & Série Maricá. \\
\hline & Discordância \\
\hline \multirow[t]{2}{*}{ Algonquiano } & $\begin{array}{l}\text { Filitos, micaxisios, cloritaxistos, hornblendaxistos, } \\
\text { quartzitos, mármores com fácies cornubianitica. } \\
\text { lntrusóes de gränitos ligeiramente alcalinos, forma- } \\
\text { cão de diques apliticos e pegmatiticos, veeiros de } \\
\text { quartzo c mineralização de estanho, tungstênio e } \\
\text { moliblênio. Formaçáo de greisen e lurmaliniza- } \\
\text { cão locais dos termos da série Porongos. }\end{array}$ \\
\hline & Discordância \\
\hline $\begin{array}{l}\text { Arqueano } \\
\text { Complexo cristalino } \\
\text { brasileiro } \\
\text { (não observado) }\end{array}$ & $\begin{array}{l}\text { Giranitos calco-alcalinos ligeiramente gnaissificados, } \\
\text { leptinitos, etc. }\end{array}$ \\
\hline
\end{tabular}


mostram, em alguns casos, coloraçào cinzenta brilho micáceo e sedoso (Campinas). Filitos e xistos concordam na sua composição mineralógica pois ambos possuem quartzo e mica como elementos esscnciais. A texlura dominante é a granuloblástica; há, contudo, xistos turmalinizados, que apresentam tipica textura nematoblástica.

Fin Cerro Branco predomina quartzo-clorita-xisto, contendo pequena quantidade de palhetas verdes de clorita e, muito raramente, pequeninos cristais de magnetita. Ocorrem xistos talcosos formados principalmente por palhetas esbrancuiçadas ou esverdeadas de talco e clorila. Fncontram-se, também, xistos talcosos que exibem, não raramente, sinais de estratificação original. Algumas vezes pode-se notar a presença de hematita terlosa que tinge os xistos de vermelho. Assim, nas proximidades de V'arzinha, encontrámos concentraçoes de hematita concordanles com os estratos dos xislos. Acreditamos que sua formaçào se deve, ta!vez, à ascenção ou descencão de soluçòes ferruginosas fue impregnaram, na sua passagem, as camadas dos xistos. Nesta mesma área aparecem xistes ligeiramente feldspatizados o que nos sugere metamorfismo de injeção oll metamorfismo "lit-par-lit" pela açào de soluçóes alcalinas do magma residual através das suas camadas. Fiste fato nos leva a concluir que houve migração dos constituintes essenciais do granito através dos vistos encaixantes (metamorfismo por embebiça, Michel Lévy ou leptinolito, nome sugerido por A. Lacroix) (itados por Lapparent (12).

fste fenomeno não se verifica somente com relação aos xistos, pois grandes massas de quartzito também se mostram impregnados de feldspalos em diversos estados de feldspatizaçáo.

Não verificámos, conludo, a presença de inclusóes de xistos no granito, fato muito comum nas áreas submetidas a fenomenos intrusivos de injeção.

O melamorfismo na região de contacto é muitas vezes, pouco evidente, devido a grande estabilidade dos minerais dos xistos originados em condiçoes de temperatura e pressão elevadas (mesozona). V Leinz A. Rarbosa e E. A. Teixeira (24) citam, à pag. 16 do trabalho referido, que a "intrusào granítica conseguiu estimular uma recristalizacáo dos xistos apenas nas vizinhanças de contacto" Mas, já pouco além desta zona de conlacto, os mincrais dos xistos, que foram formados em p.l, mais alto, permanecem estáveis nas condiçoes térmicas provocadas pela intrusão.

Os xistos são fortemente inclinados, 65-75 gráos e apresentam direç̃o constante com pequenas variaçóes locais.

Em muitas áreas êles se mostram profundamente alterados. Os quartzo-micaxistos não alterados e aqueles que se mostram par- 
cialmente decompostos exibem leilos distintos que favorecem sua separacào cm lâminas delgadas.

Quartzitos são abundantíssimos na área mineralizada, devendo-se a c̀les as principais elevacóes da área. Seu aspecto, geralmente branco, róseo e maciço, torna-o fàcilmente confundivel, à primeira vista, com os veciros de quartzo. Os quartzitos intercalados nos xistos concordam com êstes não só no mergulho, mas também na direção e, muitas vezes, sua distinção dos veeiros de quartzo se faz ou por via ólica ou no campo, pela ausência de salbandas nas regiōes de conlacto.

Além do quartzito leitoso, encontra-se comumente na região (Cerro Branco e Cerro do Inferno) quartzito !enhoso, de coloração variável e possuindo bem acentuada xistosidade, motivada aqui, pela presença de lâminas de mica (muscovita), que emprestam à rocha a capacidarle de se clivar fàcilmente, como se fosse um pedaco de lenho.

Na descricão do granito, que daremos a seguir, orientar-nosemos pelas idéas clássicas, não entrando na discussão sobre a sua origem.

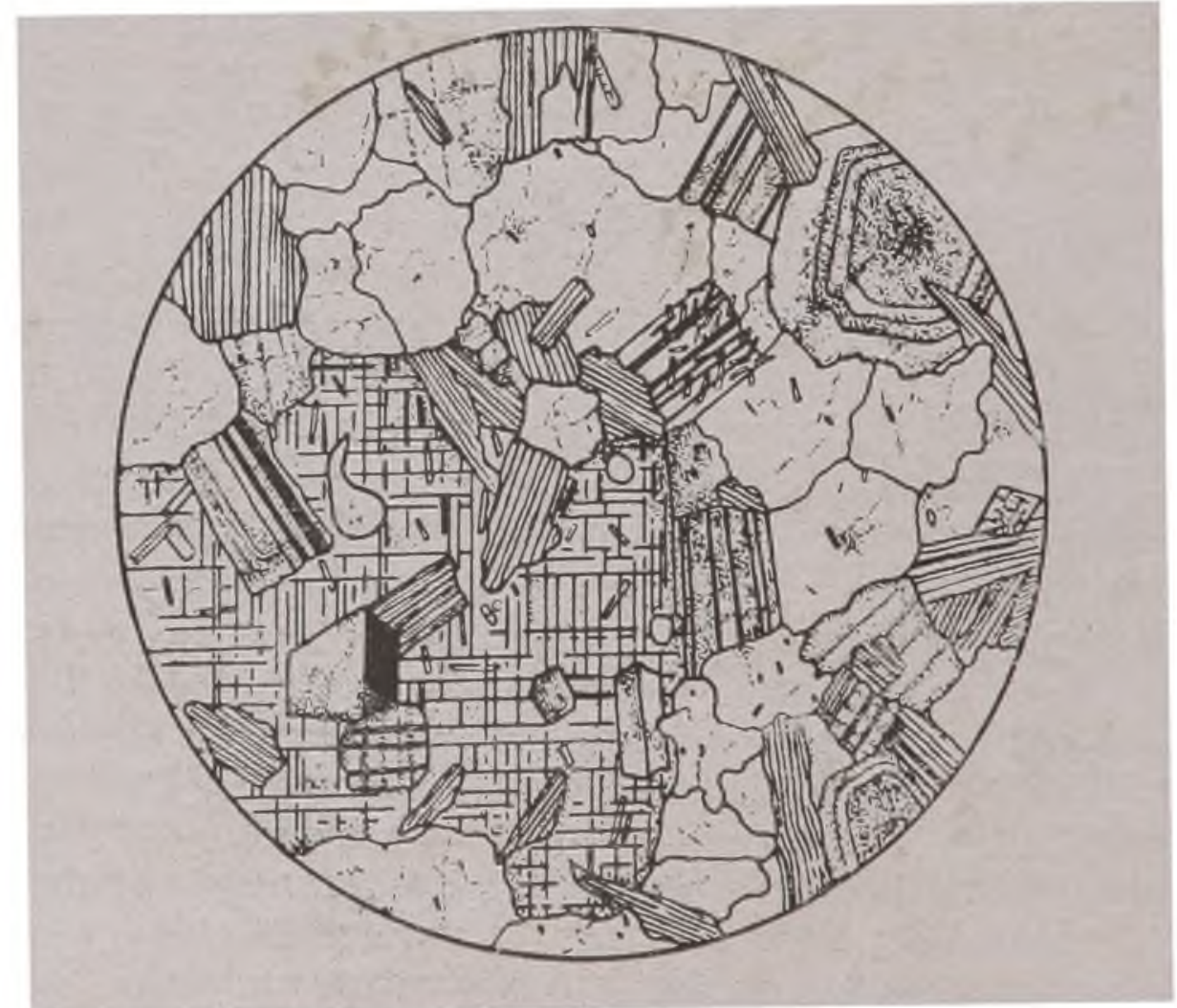

Fig. 10 - Granitc, mina Santa Bárbara, municipio de Piratini $-\mathrm{N}+\times 26$ microclínio encerrando restos de cristais de quartzo, ortoclásio e plagioclásio. Quartzo e plagioclásiozonados, muscovita e biotita, 


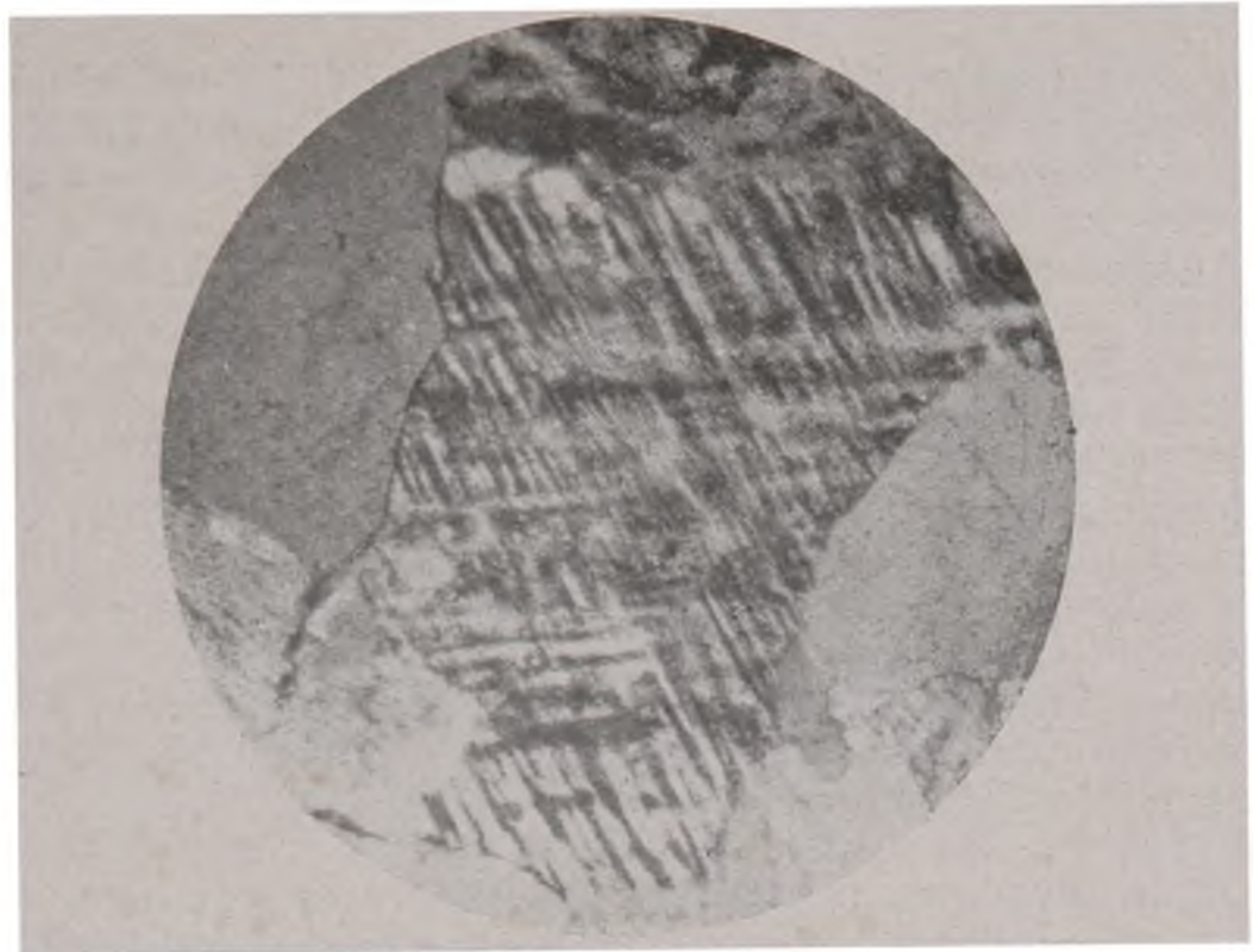

Fig. 11 - Granito, proximidades do Cerro Branco, município de Encruzilhada, $\mathrm{N}+\times 35$. microclinio encerrando restos de cristais de quartzo. Veem-se ainda cristais de ortoclásio, biotita e muscovita:

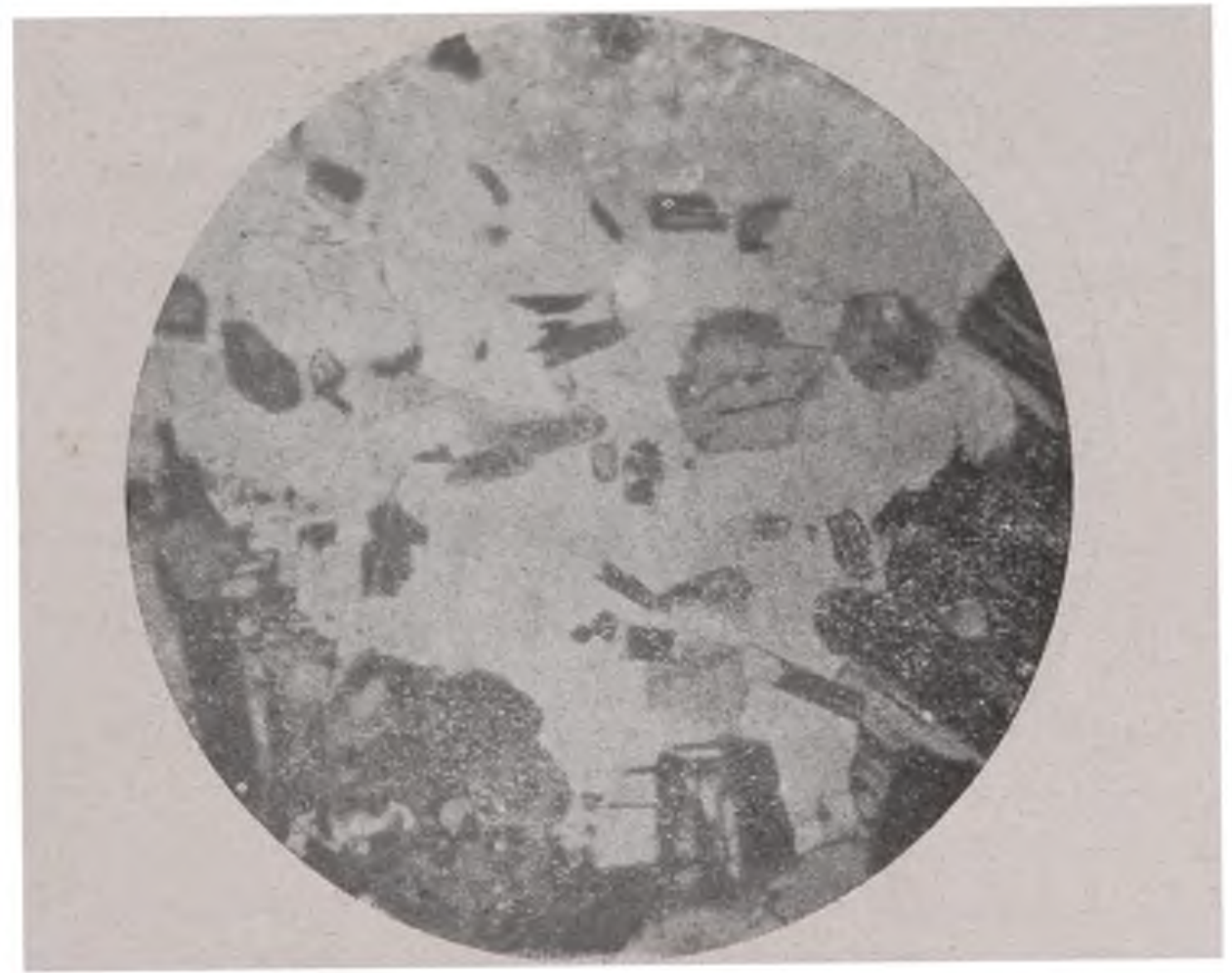

Fig. 12 - Grani'o, mina de Santa Bárbara, munícipio de Piratini, $N+\times 25$. Giande cristal de microclinio com inclusões diversas: grãos arredondados de quartzo, ortoclásio, plagioclásio zonado, bioltita e oligoclasio. 
Os afloramentos de granito apresentam-se, geralmente, com duas colorações (capítulo Mineralogênese) : em algumas áreas predomina biotita-granito e, em outras, granito a duas micas e ainda muscovila-granito.

A granulacão varia sobremancira e em algumas partes o granito exibe incipiente textura paralela motivarla, em parte, pela orientacão da biotita e muscovita. A granulacão ora normal, ora !orfiróide e mesmo pegmatóide ć devida, principalmente aos diferentes estágios de viscosidade do magma durante os processos de diferenciação que se deram por ocasião da consolidação do magna. Contudo, $\epsilon$ m qualquer dos casos considerados, nota-se sempre a seqüiencia normal de cristalização dos elementos do granito.

Nota-se nas figs. 10, 11 e 12 que o microclinio parece se ter formado posteriormente, incluindo restos de oligoclásio inalterado, oligoclásio ligeiramente albitizado, ortoclásio e quartzo, mediante processo de substituicio. Alguns, pontos exilsem cristais de microclínio invadindo cristais de ortoclásio e oligoclásio e algumas lâmina: mostram, ainda, exemplos perfeitos de microclinizacão, nas quais se notam os remanescentes do oligoclásio e ortoclásio. No granito pegmatóide os cristais de feldspatos são comumente idiomorfos e geminados.

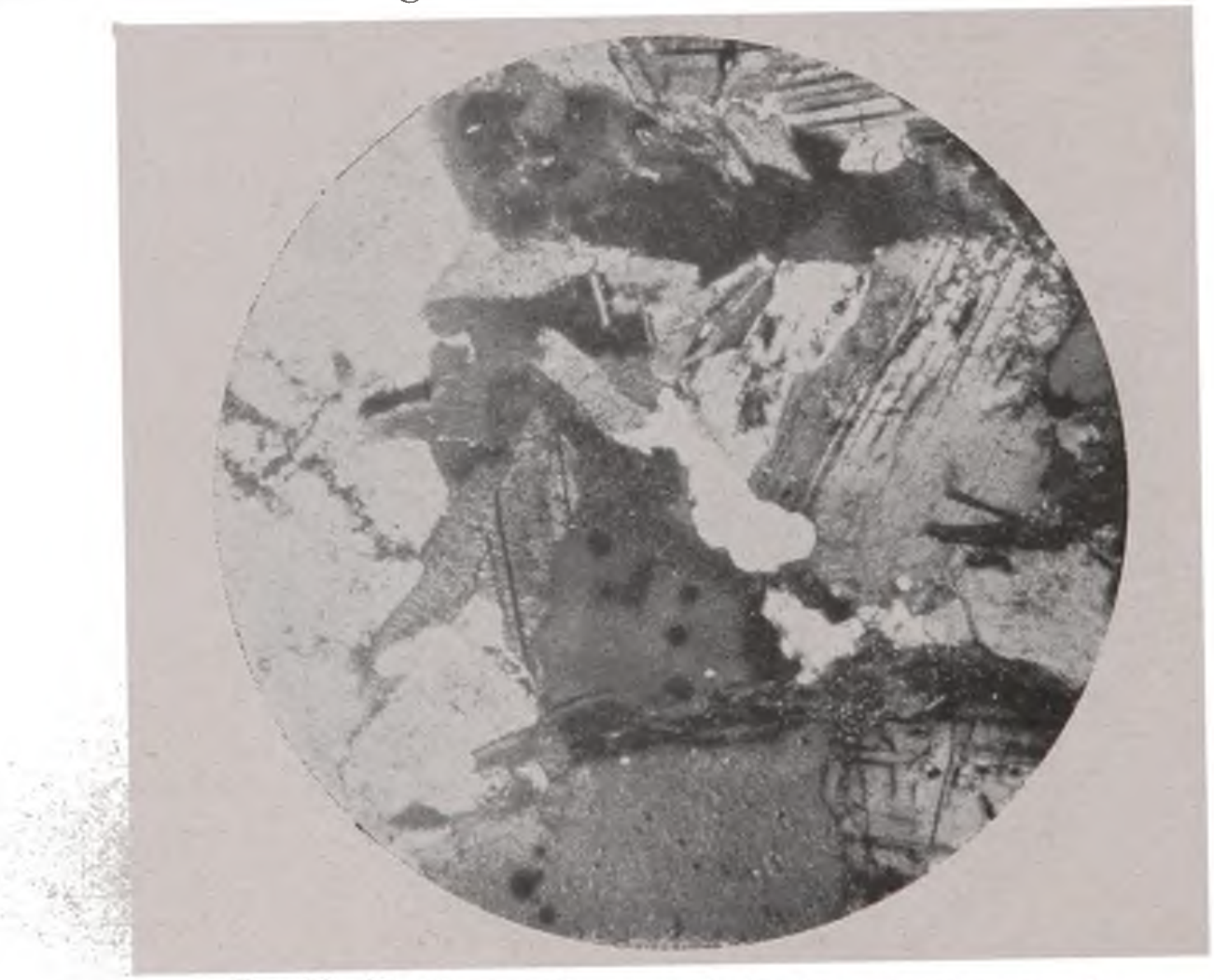

Fig. 13 - Biotita-granito, proximidades da Sanga do Butiá, municipio de Encruzilhada, $\mathrm{N}+\times 35$ Biotita mostrando o caracteristico efeito birds' eye maple. Biotita com halos pleocróicos. Oligoclásio, ortoclásio e quartzo. 
O quartzo parece ter sofrido típico fenômeno de absorção, pois algumas vezes apresenta-se como inclusões esferoidais e elipsoidais.

A composicão mineralógica é a seguinte: quartzo, oligoclásio, ortoclásio, microclinio, biotita, muscovita, apatita, zirconita e titanita.

Q u a r t zo -... Apresenta-se comumente como elemento intersticial. Não raramente vêmo-lo associado ao ortoclásio e ao plagiaclásio, formando respectivamente textura micropegmatítica e textura mirmequitica (quartzo vermicular), fig. 11. Mostra-se geralmente fraturado e com extinção ondulante. E' encontrado também sob a forma de grânulos arredondados e esferoidais no interior de cristais de microclínio e oligoclásio, proveniente nesse caso, talvez, da substituição dêstes por aquele mineral. Inclue, por sua vez, finas agulhas de apatita e grânulos microscópicos nãc identificáveis.

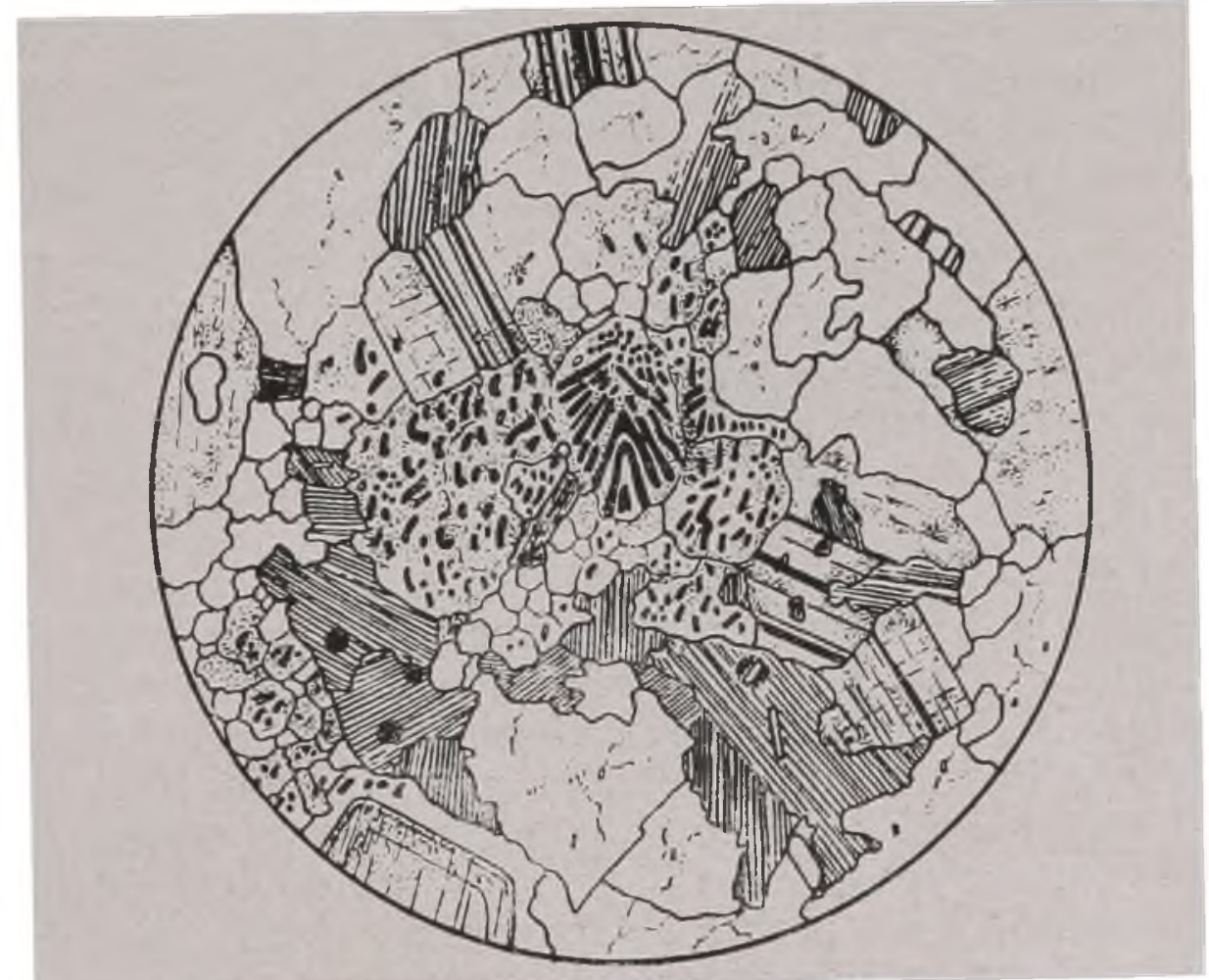

Fig. 14 - Granito, Sanga do Butiá, mun. de Encruzilhada, $\times 26$ - Fragmentos mostrando típica textura micropegmatitica. Quartzo e biotita com halos pleocróicos.

Pudemos verificar a existência de micropegmatito ao redor do ortoclásio, o que parece indicar-nos que êste mineral sofreu corrosão e suas cavidades foram posteriormente preenchidas pelo quartzo. Muitas rezes, o quartzo, geralmente sob a forma de aguthas, se distribue no interior do ortoclásio, formando concreções de estrutura radiada. 
Oligoclásio -.. E' o plagioclásio dominante, apresentando-se sob a forma de pequenos e grandes cristais geralmente geminados, segundo a lei da albila. Os cristais são, algumas vezes zonados e mostram, não raro, o núcleo alterado em sericita e muscovila. Geminam-se também segundo a combinação das duas leis, a da albita e a de Carlsbad. Incluen grande número de outros minerais: cristais de ortoclásin. gránulos arredondados e esferoidais de quartzo, muscovita primária, biotita, agulhas de apatita e bioita cloritizada. O oligoclásio forma associacão com o microclinio (perlita e micropertita). Os cristais de oligoclásio, apresentam-se, na maioria das vezes, alterados e $\mathrm{cm}$ diversos estádios de muscovitização.

Ortoclásio - Apresenta-se geralmente sob a forma de ristais idiomorfos de lamanhos variados e pouco alterados. Geminsm-se, geralmente, segundo a lei de Carlsbad; alguns individuos, no entanto, mostram incipiente geminação polissintética. Acham-se geralmente incluidos no plagioclásio e teem com êste certa orientação. Alguns cristais de orloclásio são fracamente zonados e com extincão, na maioria das vezes, ondulante. Acreditamos que o granito tenha sofrido, na sua fase final de consolidação, severas tensões que provocaram em muitas áreas, metamorfismo cataclástico, responsável pela extinção ondulante dos minerais.

Mi croclín io - Forma grandes cristais tipicamente geminados em grade Inclue restos informes de oligoclásio, ortoclásio, biotita muscovila, restos de cristais de quartzo arredondados e fragmentos de intererescimento gráfico. E' também micropertitico, (fig. 11).

Biotita - I: o único mineral fèmico e prepondera sobre todos os outros minerais acessórios. Apresenta-se, não raramente, 'em grandes cristais visíveis a olho nú. F' rica de cristais incluidos: zirconila com halos pleocróicos, agullas e cristais prismáticos de apatita e titanita algumas vezes idiomorfa. Mostra ainda evidente epigenizacão em clorila. Em alguns casos, nota-se perfeita interlaminaça entre a biotita e a muscovita, na qual os tixos cristalográficos de ambas estào perfeitamente paralelos. A biotita evidencia-se muitas vezes inteiramente lixiviada, tornando-se fàcilmente confundível com a muscovita. Ao microscópio. a identificacão é confudo relativamente fácil devido ao pequeno valor do àngulo dos eixos óticos da biotita. Na fig. 13, pode-se notar o característico efeito "birds'eye maple", cuja origem se deve provàvelmente à formarão de pequeninos buracos conseqüentes á remocão de lâminas de biotita durante o desgaste. $A$. Johaninsen (21).

Muscovita - Apresenta-se ora em grandes cristais e ora em finissinias làminas. E' incolor, nềo alterada e algumas vezes 
geminadas. Em muitos pontos pode-se nolar os efeitos deutéricos, no granito, da reação dos fluidos magmáticos sobre os minerais preformados. Assim, cristais de biotita e feldspatos se mostram, não raramente, subsituidos pela muscovita.

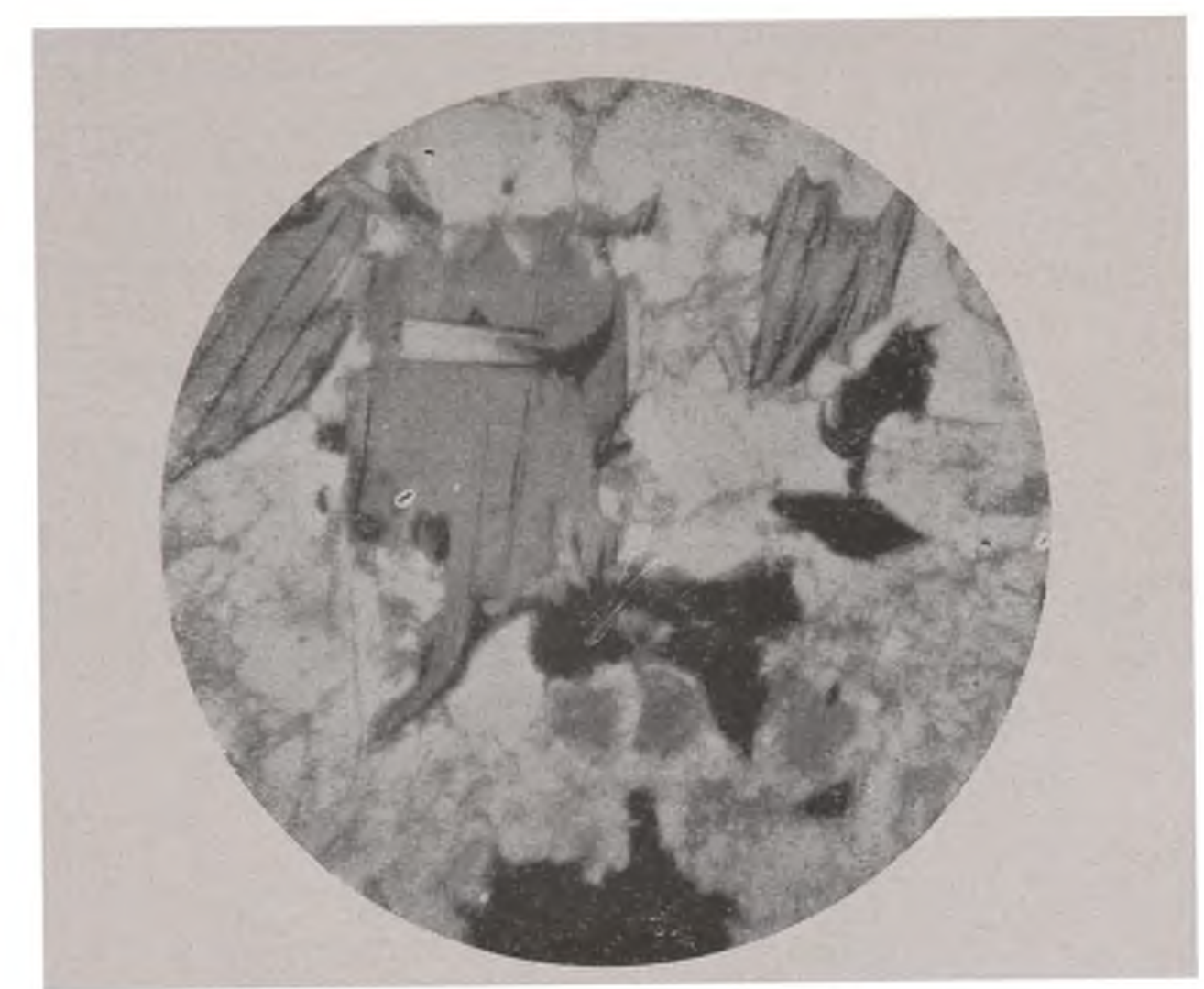

Fig. 15 - Biotita-granito, proximidades da Sanga do Butiá, L.N. ×35. Cristais de biotita e quartzc.

A patita, zirconita e titanita encontram-se sempre incluidas, idiomorfas e em proporções reduzidas.

En neuhuma das lâminas estudadas pudemos verificar a exislência de cristais de turmalina e cassiterita como elementos conslituintes do granito. Esste fato nos conduz à conclusão que êstes dois minerais não constitucm elementos essencialmente primários, como acontece com os que acabámos de descrever. Ambos não devem ser considerados minerais pirogenéticos no sentido em que esta pajavra é geralmente tomada, mas formados juntamente com o material magmático residuário, intimamente ligado aos constituintes voláteis do magma primitivo. Von Miklucho-Maclay (38) (ita, entretanto, a cassierita como mineral incluso na mica preta no granito de Greifensteiner (Ehrenfriedersdorf)

Abaixo damos duas análises de granitos que ocorrem em dois pontos afastados, dentro da área mineralizada: 
I

$$
\begin{aligned}
& \text { Granito - Sanga Butiá } \\
& \mathrm{SiO}_{2}-66,75 \\
& \mathrm{P}_{2} \mathrm{O}_{5}-0,26 \\
& \mathrm{TiO}_{2}-0,33 \\
& \mathrm{Al}_{2} \mathrm{O}_{3} \ldots 18,47 \\
& \mathrm{Fe}_{2} \mathrm{O}_{3}-3,46 \\
& \mathrm{MgO}-0,16 \\
& \mathrm{CaO}-3,32 \\
& \mathrm{Na}_{2} \mathrm{O}-2,62 \\
& \mathrm{~K}_{2} \mathrm{O}-4,48 \\
& \mathrm{H}_{2} \mathrm{O} \quad \ldots \quad 0,74 \\
& 100,59 \%
\end{aligned}
$$

\begin{tabular}{|c|c|}
\hline & $-65,64$ \\
\hline $\mathrm{P}_{2} \mathrm{O}_{5}$ & 1,22 \\
\hline & 0,43 \\
\hline $\mathrm{Al}_{2} \mathrm{O}_{3}$ & $-\quad 15,11$ \\
\hline $\mathrm{Fe}_{2} \mathrm{O}$ & $-\quad 4,04$ \\
\hline $\mathrm{MgO}$ & 0,65 \\
\hline $\mathrm{CaO}$ & 2,62 \\
\hline $\mathrm{Na}_{2} \mathrm{O}$ & 4,13 \\
\hline $\mathrm{K}_{2} \mathrm{O}$ & 5,29 \\
\hline $\mathrm{H}_{2} \mathrm{O}$ & 1,83 \\
\hline
\end{tabular}$$
\text { P. esp. } 2,73
$$

II

Granito - Mina Paulista

P. esp. 2,68

(Analista - Paùo Mathias)

Finalmente. a fig. 16 nos dá idéia da composição mineralógica e da textura dos mármores da série Porongos e que apare-

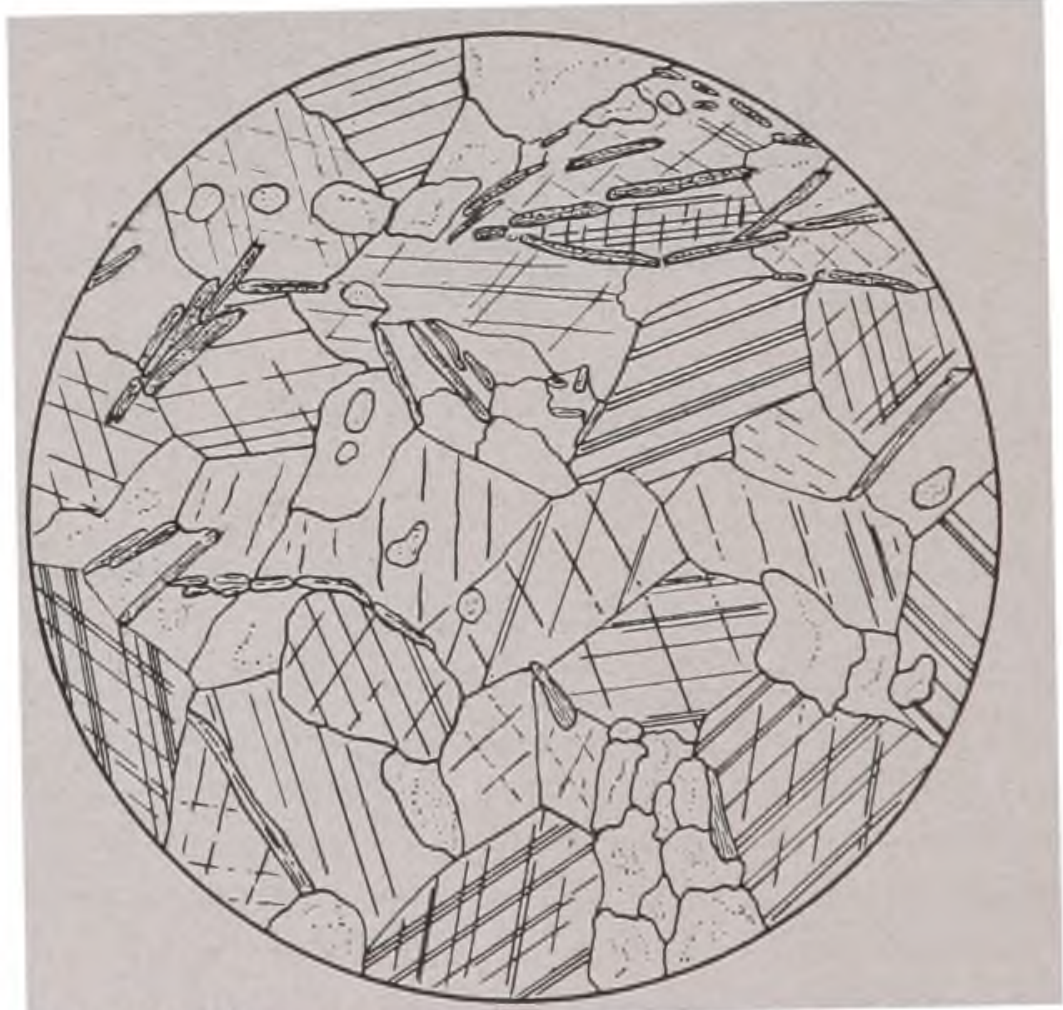

Fig. 16 - Mármore da série Porongos mostrando cristais de calcita, lâminas de muscovita incolor, quartzo e silicatos de magnésio e cálcio.

cem nas regióes circunvizinhas à faixa estanífera. Os mármores são geralmente dolomíticos e mostram, algumas vezes, entre os 
cristais de calcita, lâminas de muscovita incolor e outros hidrosilicatos de magnésio e cálcio dificilmente identificáveis ao microscópio. Os mármores são ricos de cristais de quartzo.

\section{b) Devoniano}

Como se pode varificar no mapa geológico anexo, a série Camaquan está representada somente em dois pontos da região estuciaria -- região do Taboleiro e $\mathrm{cm}$ pequena área do Arroio dos Vargas. Na região do Taboleiro esta série é constituida principalmente de arenitos arcosianos e arenitos avermelhados. Os areni-

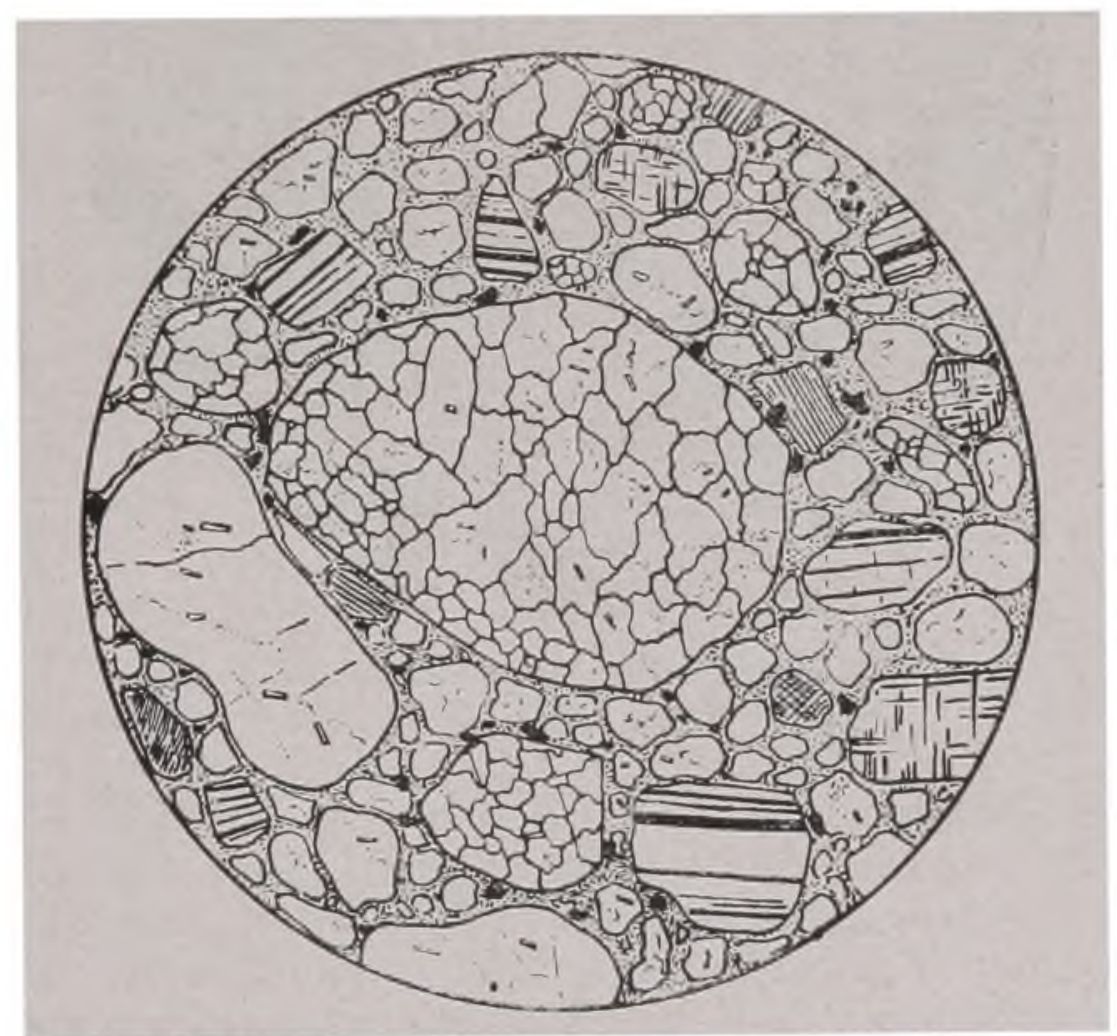

Fig. 17 - Arenito arcosiano, mina do Taboleiro, mun. de Encruzilhada. No centro um grande seixo rolado de quartzito. Veem-se também cristais de plagioclásios, $\times 26$.

tos vermelhos são ricos de mica e os arcosianos mostram-se de duas côres: esbranquiçada e vermelha. Há regiões onde se pode notar perfeita estratificação dessas cores. Os arenitos arcosianos são formados por minerais diversos: quartzo, feldspato, seixos rolados de quartzito e, muito raramente, muscovita (fig. 17). Existem áreas, em que predominam fragmentos de clivagem de feldspato residual que foi preservado do intemperismo e erosão. A despeito da idade de tal formação (devoniano?), os feldspatos (plagioclá- 
sios, ortoclásio, microclinio e microclínjo-micropertílico) achamse, na sua quase totalidade, não muito alterados (fig. 18).

Algumas partes dêsle arenito arcosiano são de granulação grossa e mostram maior proporção de microclínio do que de plagioclásio.

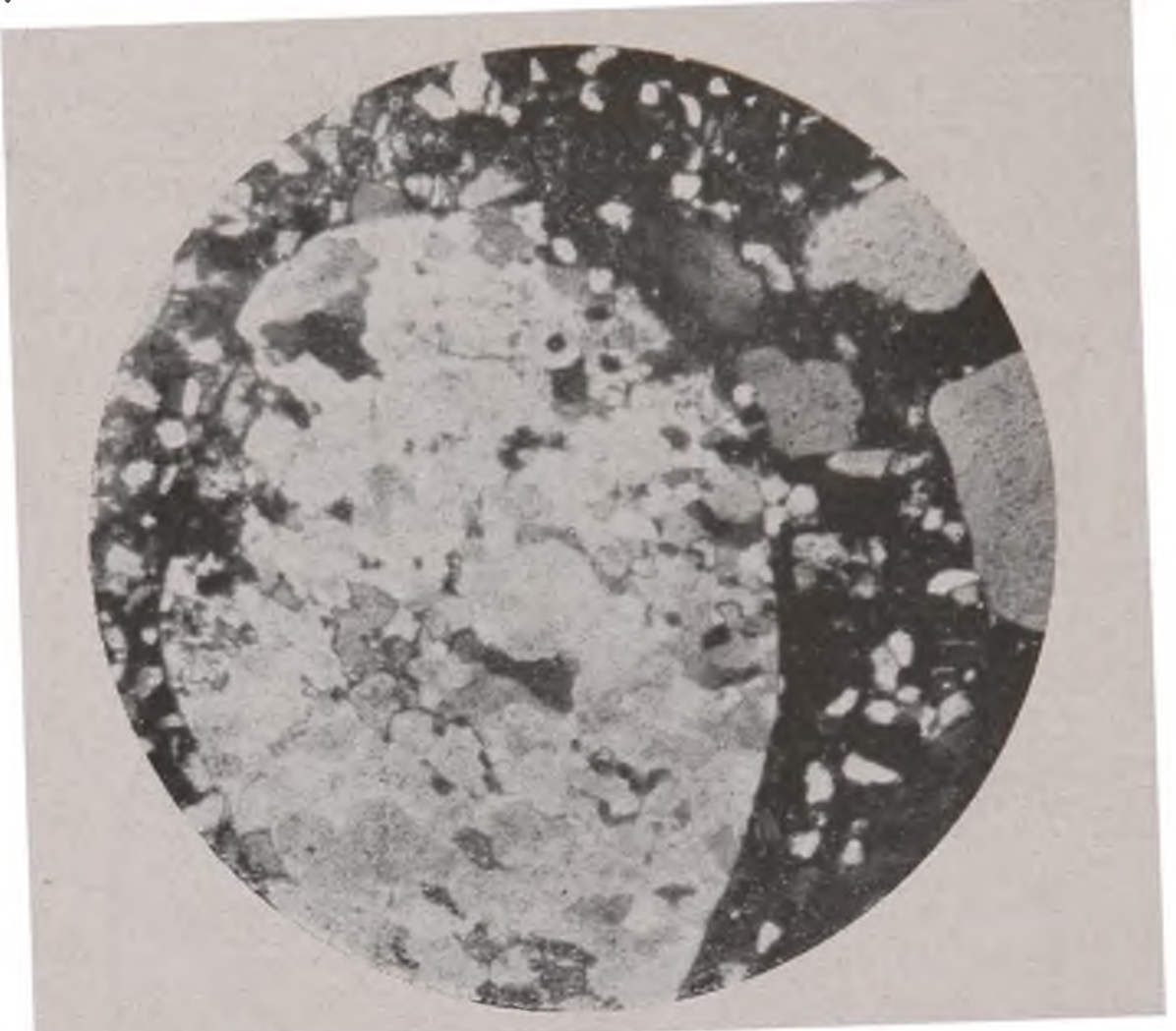

Fig. 18 - Arenito arcosiano, mina do Taboleiro, municipio de Encruzilhada. $\mathrm{N}+\times 35$.

Como minerais acessórios, encontram-se óxidos de ferro e raríssimos minerais estáveis. Quartzo e grãos de feldspato mostram geralmente extinção ondulante. Há zonas, onde o arenito se apresenta com cimento calcáreo, originado provàvelmente dos mármores, que abundam na região. () cimento em geral é constituido por material silícico-argiloso não identificável ao microscópio.

Na região do Taboleiro está em posição horizontal, não mostrando sinal algum de ter sofrido influencia de tectonismo local. Os termos da série Camaquan assentan em discordancia sobre os granitos e xistos.

\section{Mineralogênese}

a) Introdução

Para compreendermos toda fase mineralogenética daremos abaixo o quadro da seqüência normal de segregação, durante e 


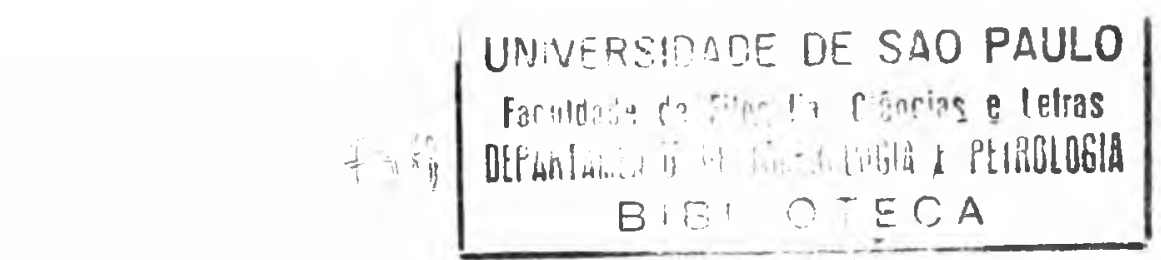

A faixa estanifera do Rio Grande do Sul 4 AER 67

após a intrusão granitica. Contudo, a seqüùncia de segregação, tal qual será esboçada abaixo, não ć tão rigida que possamos representar o fenomeno em compartimentos estanques, porquanto há muitos pontos de transiçĩo entre uma e outra fase de cristalização. Devemos mencionar ainda que, no curso de una fase de cristalização, elementos voláleis de outra fase deven ter agido sobre os minerais em formacão, seja modificando a ordem de cristalização, seja ocasionando a precipitação de minerais que não deviàm existir alí.

Seqüència normal de cristalização

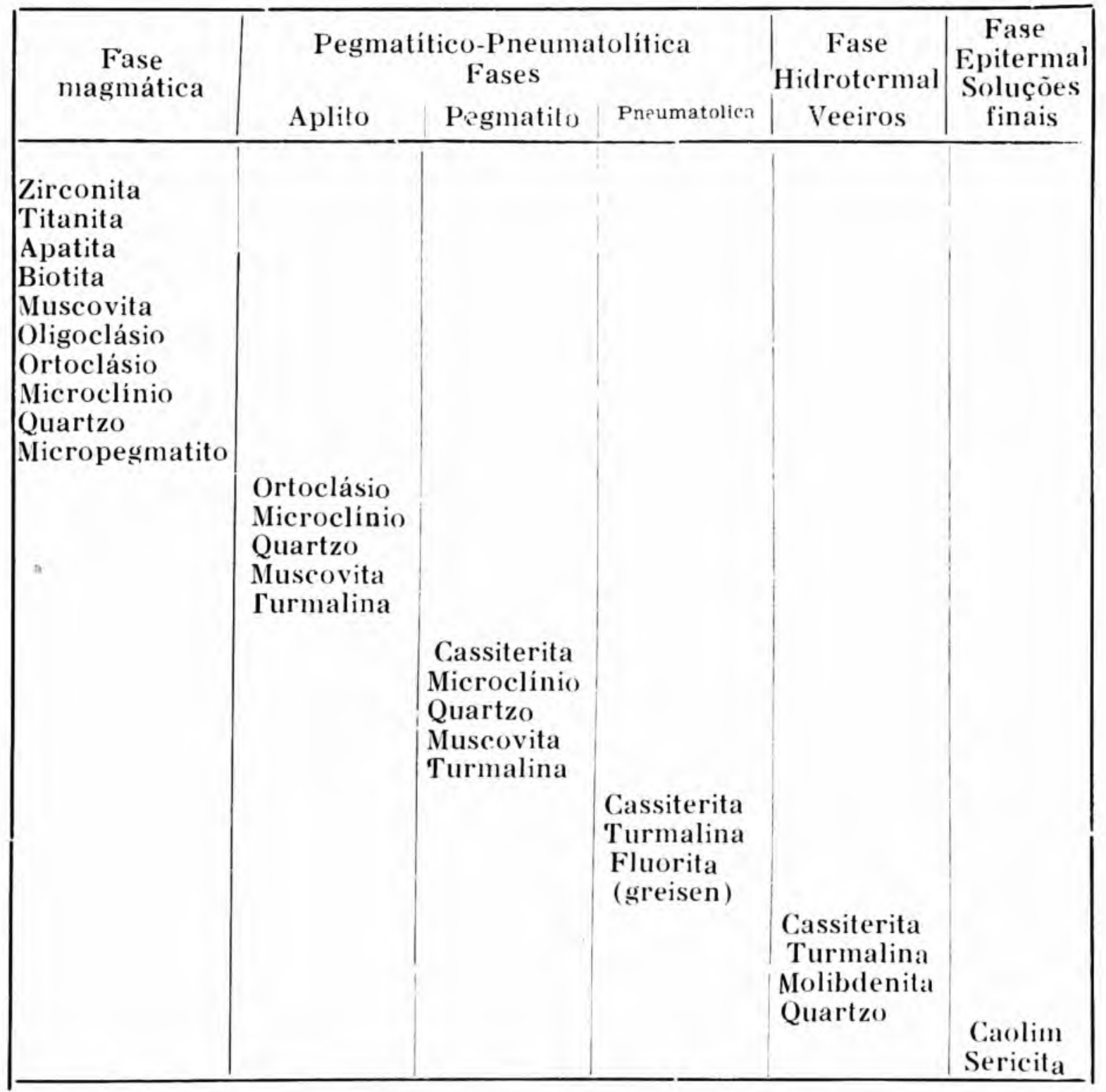

Iniciaremos nossas consideraçoes pelo magma ácido que devería ter sido, originariamente, rocha simples, tendo como elementos essenciais, - oligoclásio, ortoclásio e quartzo e.como elementos 
acessórios, biotita, apatita, zirconita e titanita. Denominaremos esta rccha - biotita-granito, mesocrático, conhecido também pelo nome de granitito.

Com o empobrecimento sempre crescente dos elementos ferro-magnesianos, consequiente à formação da biotita, único elemento fèmico, surgiram ein muitas áreas dêste biotita-granito, faixas de diferenciacão, formando-se, agora, granito a duas micas. Ao lado dèste granito formon-se também, granilo leucocrático, tendo como elemento acessório principal, não a biotita, mas sim a muscovita.

Ocorrem regiões nas quais se verifica típica diferenciação porfiróide do granito primitivo, notando-se a existência de cristais relativamente grandes de microclínio, mica e quartzo. Possivelmente esta modificação estrutural se verificou por influência de trans. formações deutéricas, com formaço de cristais bem desenvolvidos. Tais rochas (granitos porfiróides) se prestam muito bem aos estudos genéticos pela sua texlura grosseira e relação espacial de seus minerais. Nestas rochas, os cristais de microclinio são, na maioria das vezes, mais desenvolvidos do que os cristais de mica e quartzo, daí o seu caracter porfiróide.

Finalmente, como última faixa de diferenciação ou segregação diferenciada, ocorrem, mais exteriormente, no muscovita-granito,

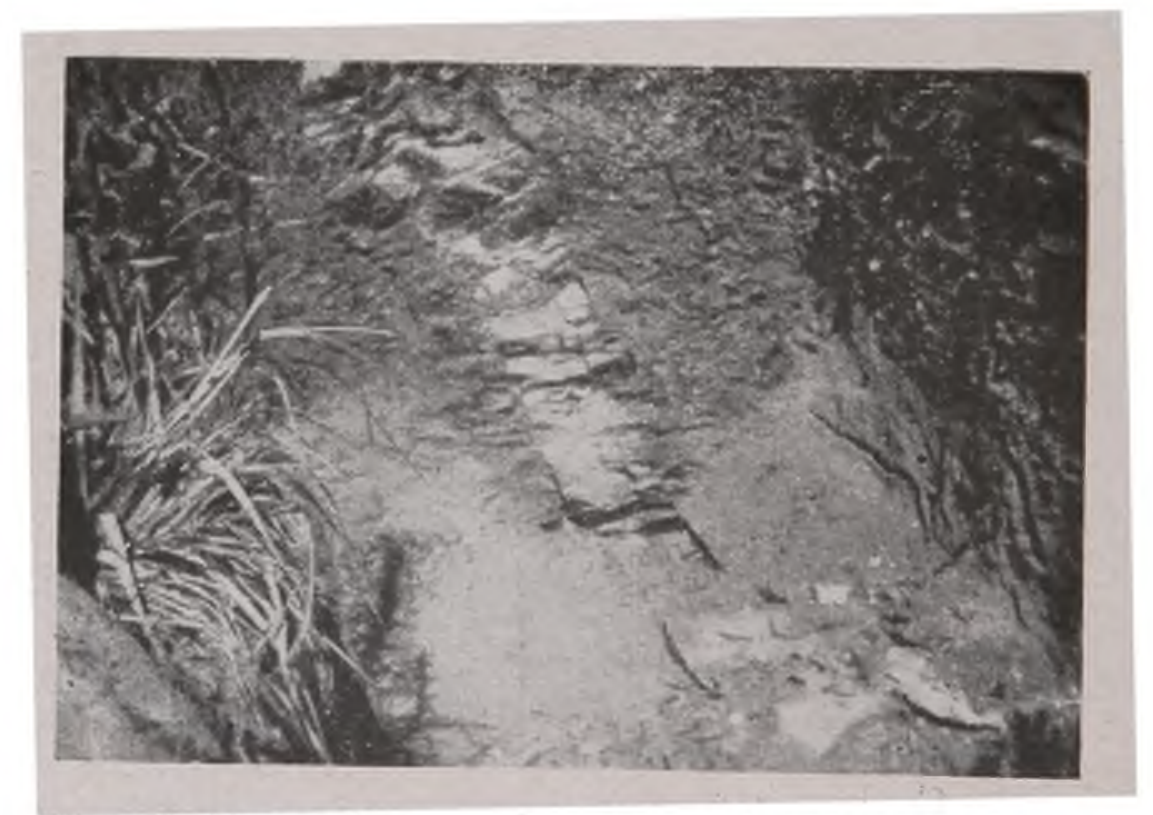

Fig. 19 - Veeiro de quartzo no granito alterado, mina Campinas, municipio de Encruzilhada.

a área filoniana, rica de aplitos, pegmatitos e veeiros de quartzo, geralmente turmalinizados. Eslas últimas formaçōes representam, nada mais nada menos, do que o último estágio da diferenciação 
do magma biotita-granito primitivo. Sem dúvida, estas diferenciações, devem ter-se operado em conseqüência das infiltrações magmáticas através do granito em formação, que assim se foi mo-

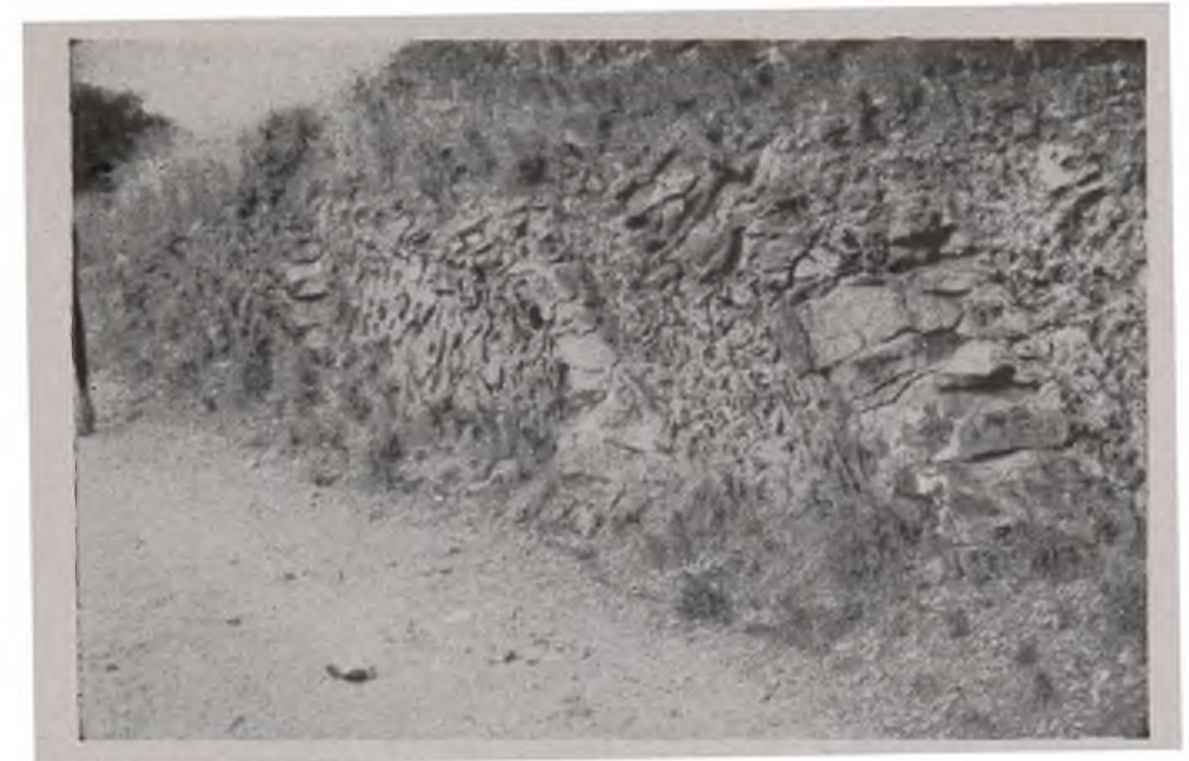

Fig. 20 - Veeiros de quartzo nos xistos da série Poiongos, Cordilheira do Estreito, municipio de Encruzilhada.

dificando gradativamente para os termos mais ácidos e leucocráticos.

Fenômeno aproximadamente idêntico a êsse, foi observado por Blaise e Boutakoff (6) nos batolitos graníticos de Kivu (Congo Belga), onde êstes Autores verificaram, entretanto, que a diferenciação se processou em camadas sucessivas distintas, formando auréolas diferenciadas sob a forma de cúpolas.

As diferenciações mais ácidas, em nosso material, se mostram mais nítidas nas apófises graniticas, nas quais existe sempre maior quantidade de mica branca. Há, entretanto, em todas as áreas graníticas, marcada similaridade mineralógica, apresentando-se os granitos quase sempre a mesma composição química.

Foi durante a fase final de consolidaç̃o, nas áreas de diferenciação mais ácida, quando o granito sof reu severas tensões nas suas partes já solidificadas, que se formaram as inúmeras fendas e fraturas preenchidas posteriormente pelo material magmático (rest-magmas de Vogt). Originaram-se, assim, os diques de pegmatito e aplito e os veeiros hipotermais de quartzo.

Dada a existência de numerosos pegmatitos, a formaçĩo de concrescimentos micropegmatíticos e mirmequíticos no granito, a riqueza do núcleo granítico em biotita, a falta de albitização evidente e abundante e ainda a falta de textura miarolítica das intrusivas ácidas, somos levados a acreditar que eslas intrusões, 
responsáveis pelos pegmatitos, aplitos e filões, se tenham solidificado en zonas proftindas dos xistos metamórfices.

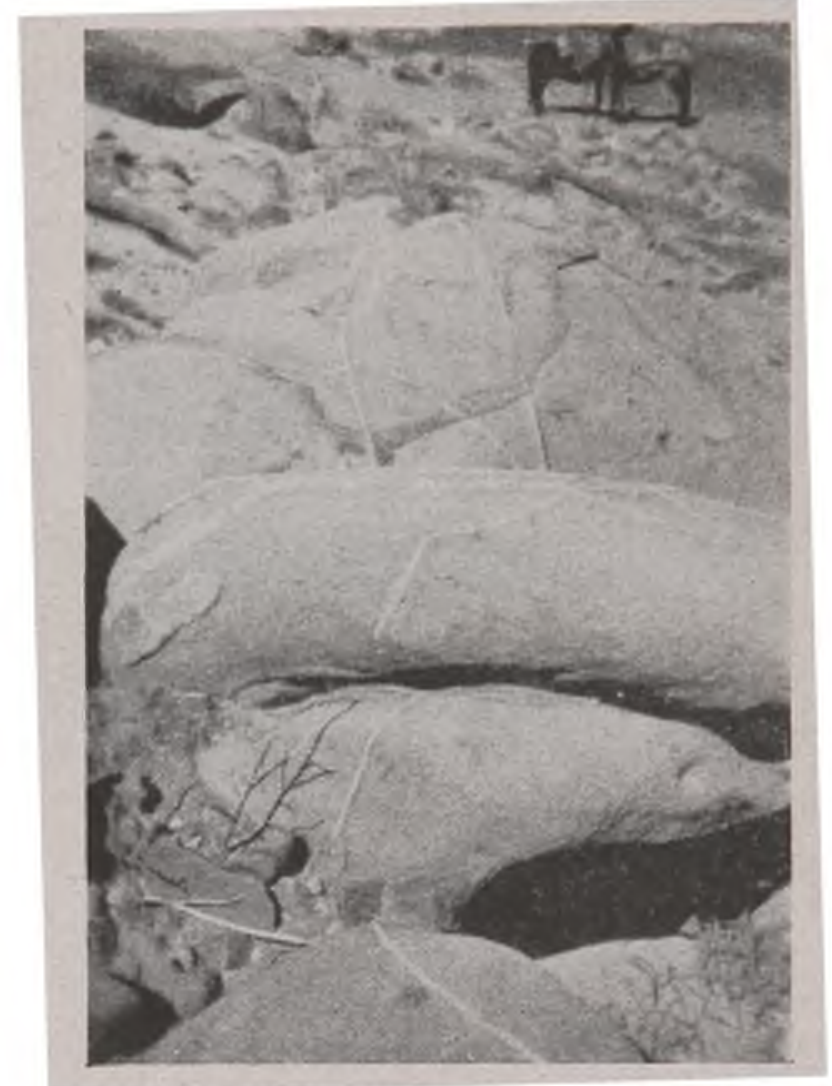

Fig. 21 - Muscovita - granito com numerosos aplitos de quartzo e ortoclásio, Rio Camaquan, mun. de Encruzilhada.

\section{b) Turmalinização 'e greisenficação}

Antes de passarmos ao estudo particular e pormenorizado dos corpos mineralizados (pegmatitos, aplitos e filões), abordaremos, ainda neste capítulo, a questão da turmalinização do granito, dos xistos e quartzitos e a da formação de "greisen" na região por nós percorrida. Cabe dizer aquí que èsses fenomenos, bem generalizados em quase toda área mineralizada, constituem bom indício nas pesquizas de jazidas, porquanto a turmalinização e a greisenficação são muito frequentes nas vizinhanças dos diques e veeiros portadores de cassiterita.

Com referência ao primeiro fenômeno, desejamos mencionar que a maioria dos depósitos de cassiterita do mundo se acham sempre associados a rochas que sofreram parcial ou total turmalinização. Assim, os depósitos de Cornwall, Inglaterra; o clássico depósito mineralizado de Altenberg-Zinnwald, Saxònia; os importantes depósitos de cassiterita encontrados nos veeiros da Bolívia; os filóes e pegmatitos greisenficados da região de Kivu, Congo 
Belga (6); os depósitos da província de Kochiu, China; os depósitos situados em Burma; os da Península Malaia e muitas outras ocorrências, mostram-se sempre associados a rochas (granitos e xistos) extensamente turmalinizadas, (IV. Lindgren (27), L. de Launay (13) e Beyschlag-Krusch-Vogt (5)).

No Rio Grande do Sul, onde a cassiterita ocorre em pegmalitos e veeiros hipotermais encaixados no granito e nos xistos, existe também forte e bem pronunciada turmalinização abrangen-

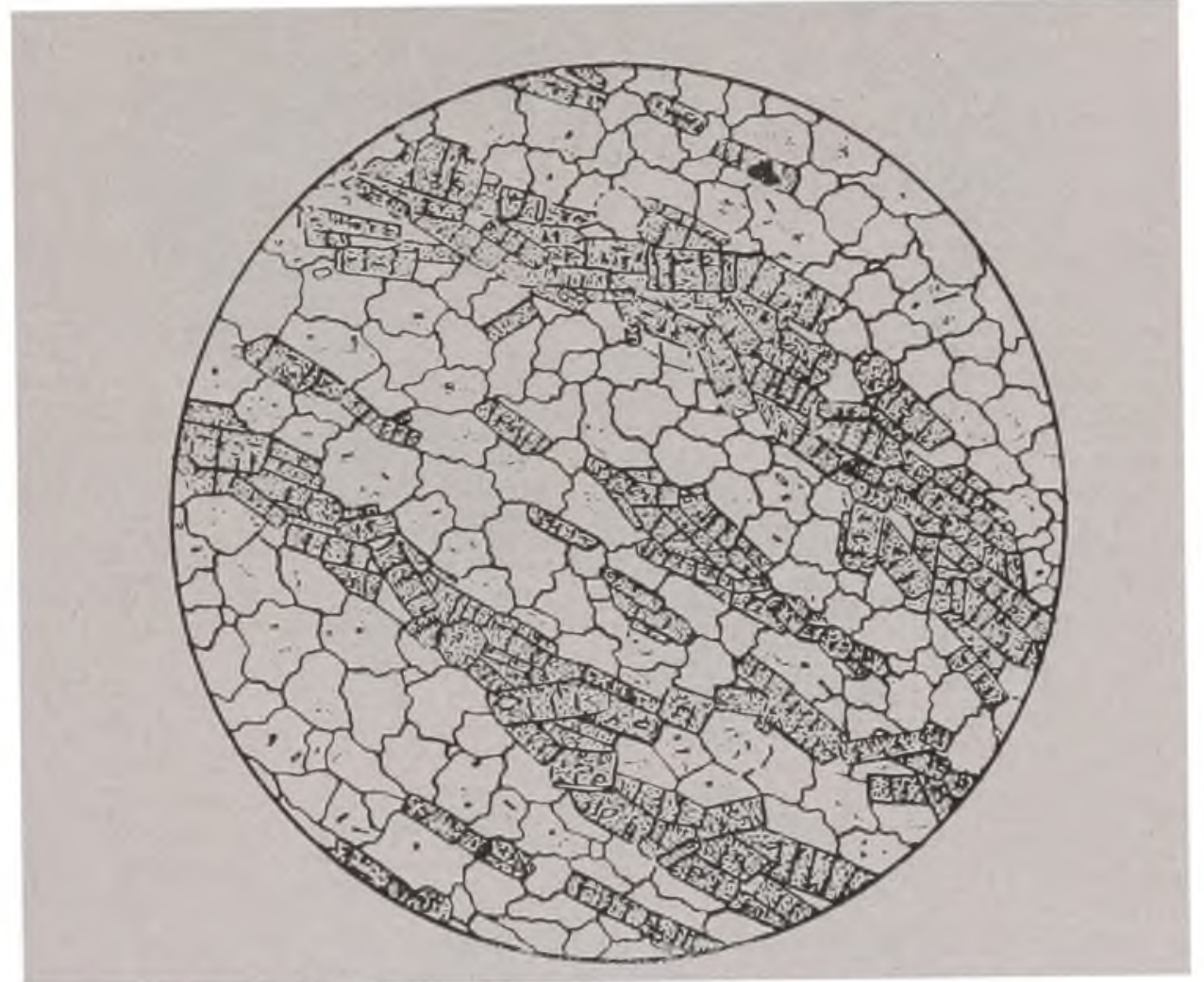

Fig. 22 - Quartzito turmalinizado, Cerro Branco, mun. de Encruzilhada $\times 46$ - Turmalina (escuro), quartzo (claro) .

do áreas bem exlensas. Nos pegmatitos, a turmalina ocorre junlamsute com microclínio, quartzo e mica. Nos aplitos, apresenla-se sol a fórma de nódulos disseminados entre o quartzo, ortoclásio e microclínio e nos filóes de quartzo, em nódulos e concrecões irregulares intimamente ligada a èsse último mineral. Em qualquer destas ocorrências a turmalina quase sempre se apresenta sob forma microscópica, com perfeita idiomorfia e de coIolacão azul acinzentado (figs. 21, 25, 26 e 27). Nos xistos e quartzitos, a turmalina é encontrada, não somente nos planos de xistosidade e em perfeila orientação neles, mas lambém disseminada em toda a rocha. Como falta completamente a turmalina no granito propriamente dito, aparecendo somente nos diques e filoes, somos levados a admitir a formação dêste mineral, como o resultado do processo pneumatolítico verificado nos últimos es- 
lágios da precipitação das soluçóes residuárias. A nosso ver, o ácido bórico, o flúor e o vapor d’água como dissolvente, teriam ascendido pelas fendas e fraturas naturais e precipitado sob a fórma de turmalina, depois do ataque dêsses elementos sobre os minerais preformados. Provàelmente a formação da turmalina não

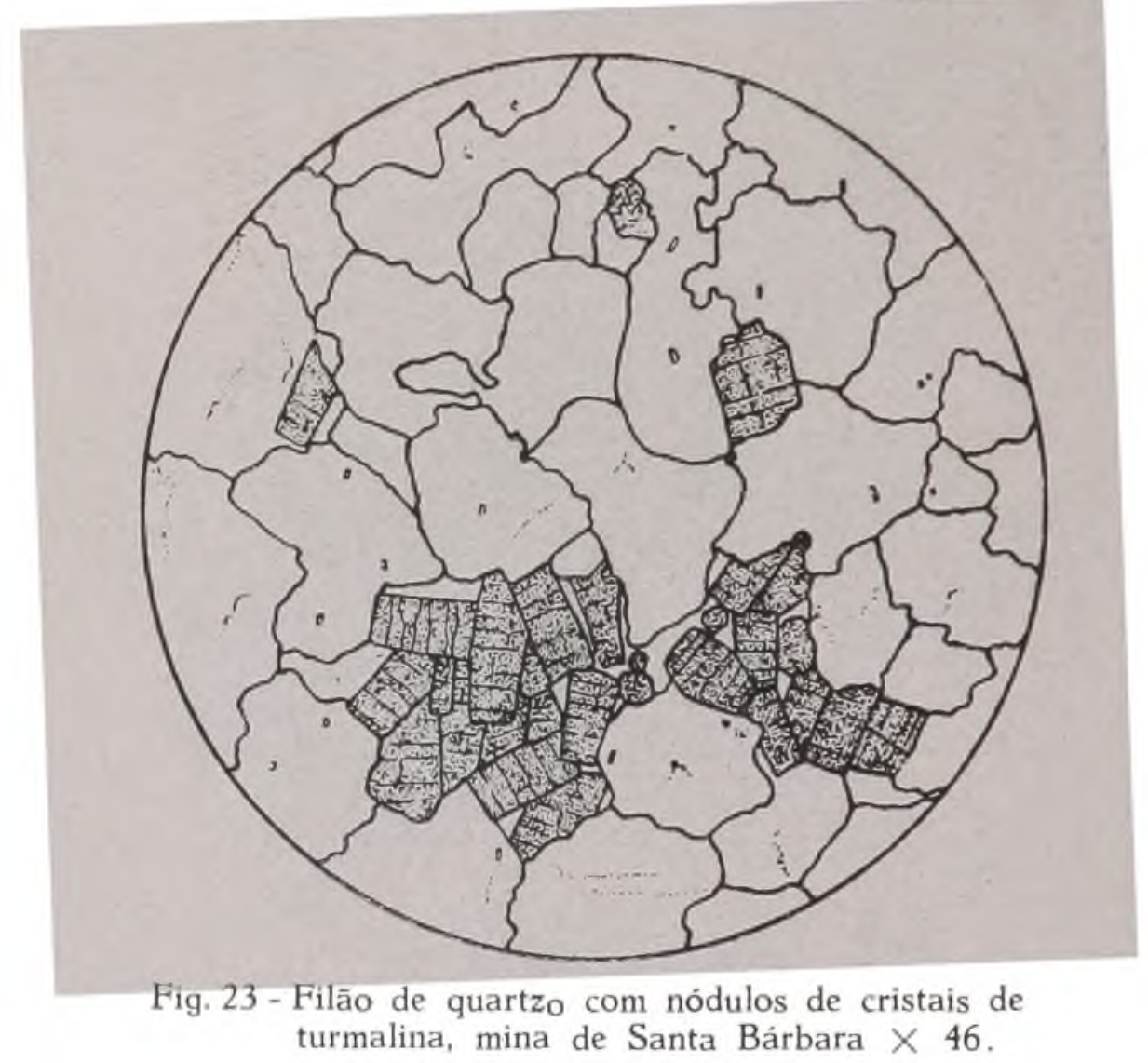

somente se verificou desta maneira, mas também por processo, em que os feldspatos já solidificados foram parcial ou totalmente substituidos por èste mineral (figs. 26 e 27 ).

Do estudo dos modos de ocorrência da turmalina, nosso principal objetivo é mostrar que sua formação é toda ela devida a processos hidro-pneumatolíticos, faltando, completamente, turmalina pirogenética. Nessé sentido, Clarke (11) estabelece que nas rochas ígneas, a turmalina parece ter sido formada pela ação de fumarólas e não como mineral originado por separação direta do magma.

Considerando a constante associacão turmalina-fluorita-cassiterita, evocámos o ácido bórico, o vapor d'agua e o flúor. como os prováveis agentes mineralizadores que desempenham papel importante na formaça da turmalina e cassiterita.

Ao contrário do que se observa com relação aos xistos e quarlzitos, que se mostram fortemente turmalinizados, com formação de verdadeiros "schorl-rock", - os granitos, qualquer que seja sua composição mineralógica, são fracamente ou quase nada tur- 


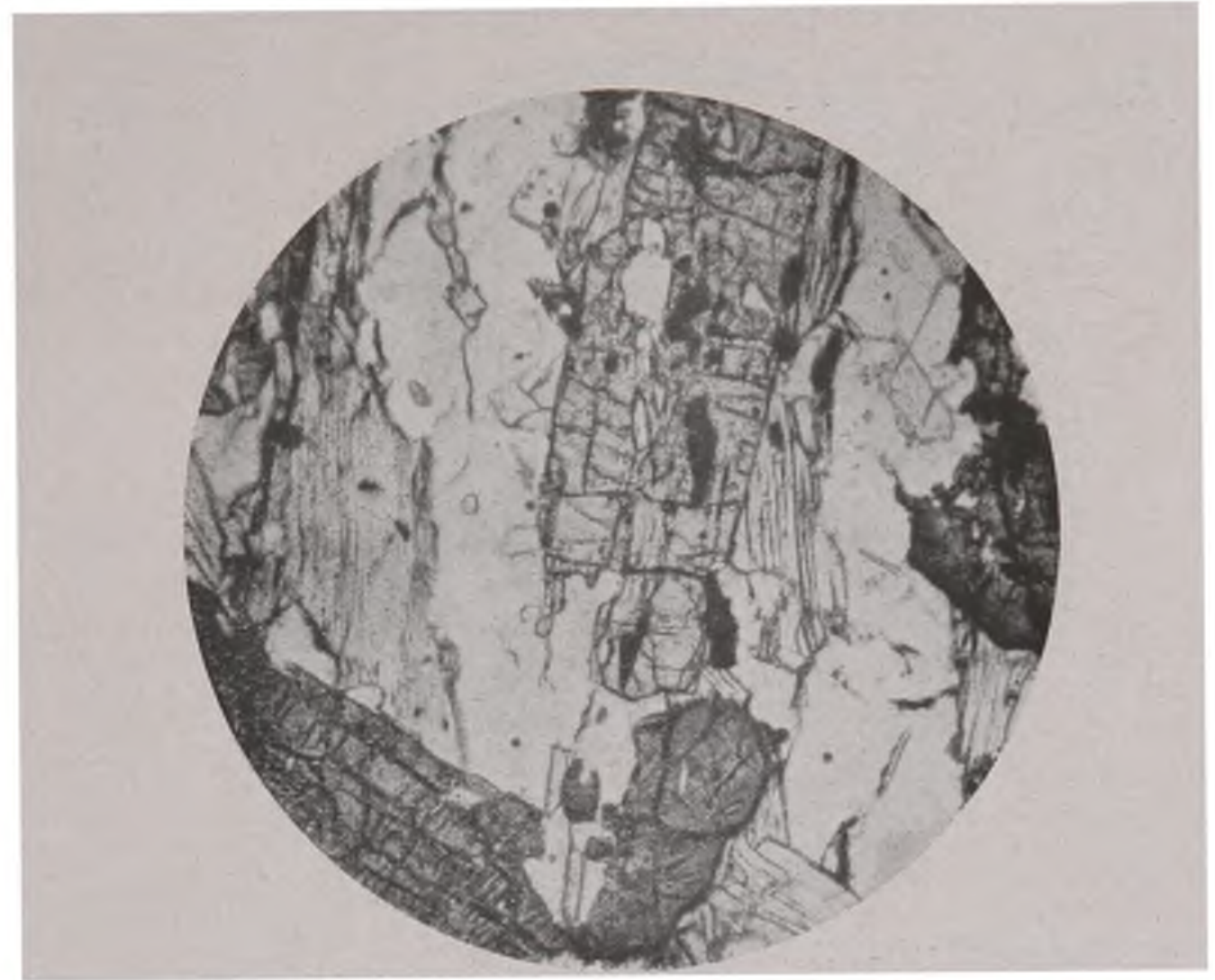

Fig. 24 - Micaxisto turmalinizado, mina Campinas. Turmalina apresenta-se idiomorfa e com alto relêvo. L.N. $\times 35$.

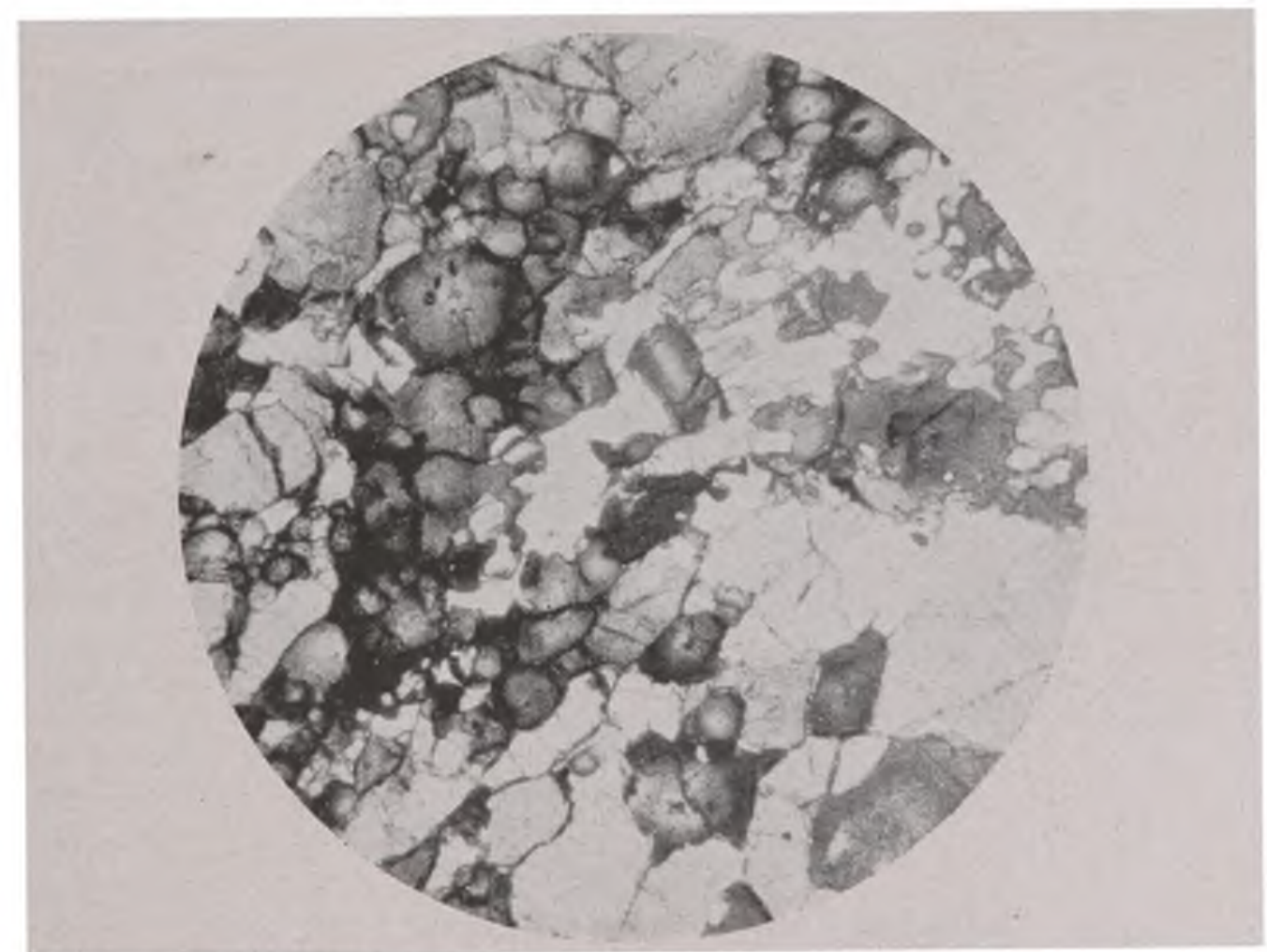

Fig. 25 - Quartzito turmalinizado, mina Cerro Branco. mun. de Encruzilhada, L.N. $\times 35$. - Cristais de turmalina, na maior parte, em secções normais ao eixo ótico. 


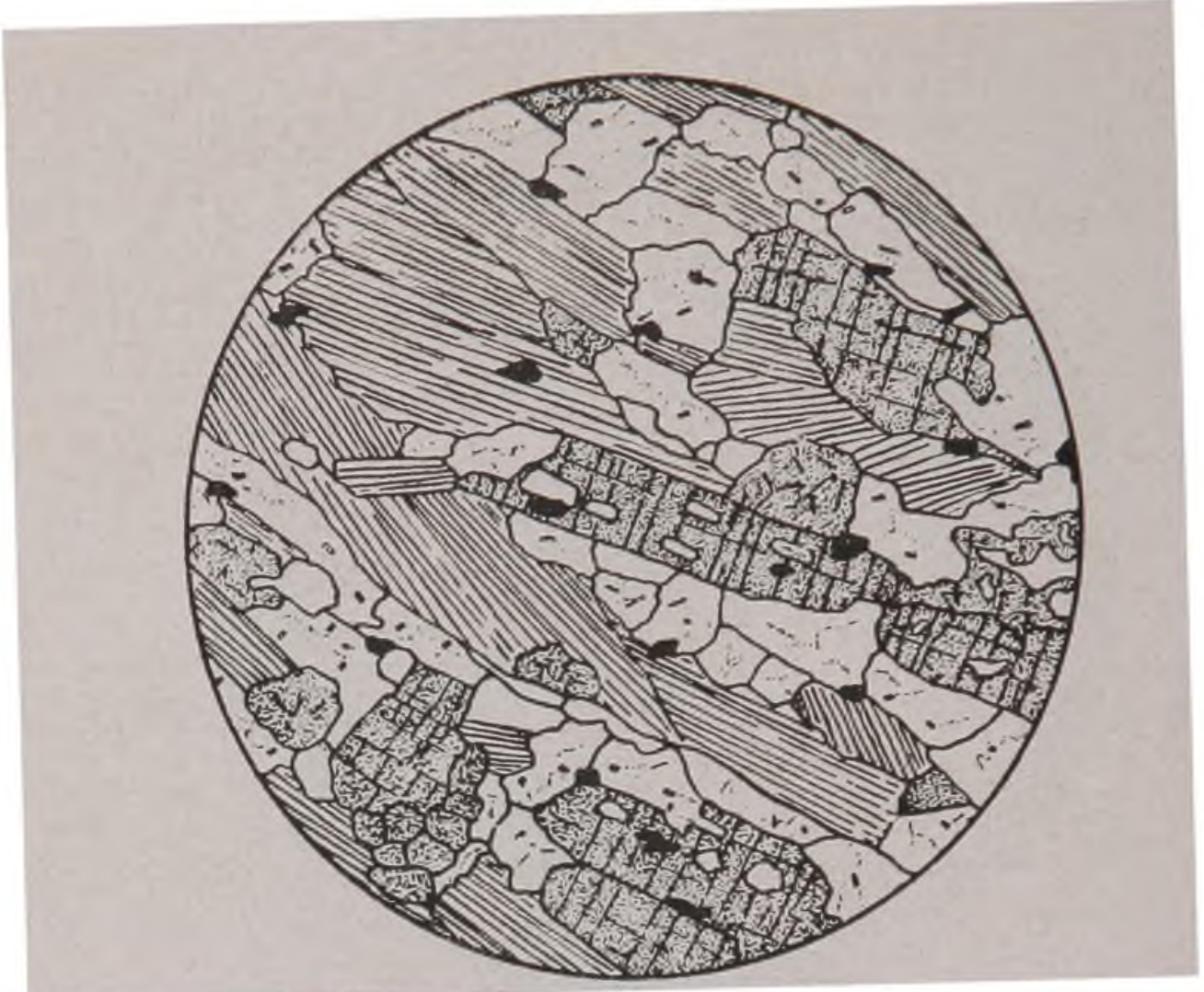

Fig. 26 - Micaxisto turmalinizado, mina Cerro Branco, mun. de Encruzilhada, Cristais de turmalina encerrando restos de cristais de quartzo. Quartzo, muscovita e limonita $\times 26$.

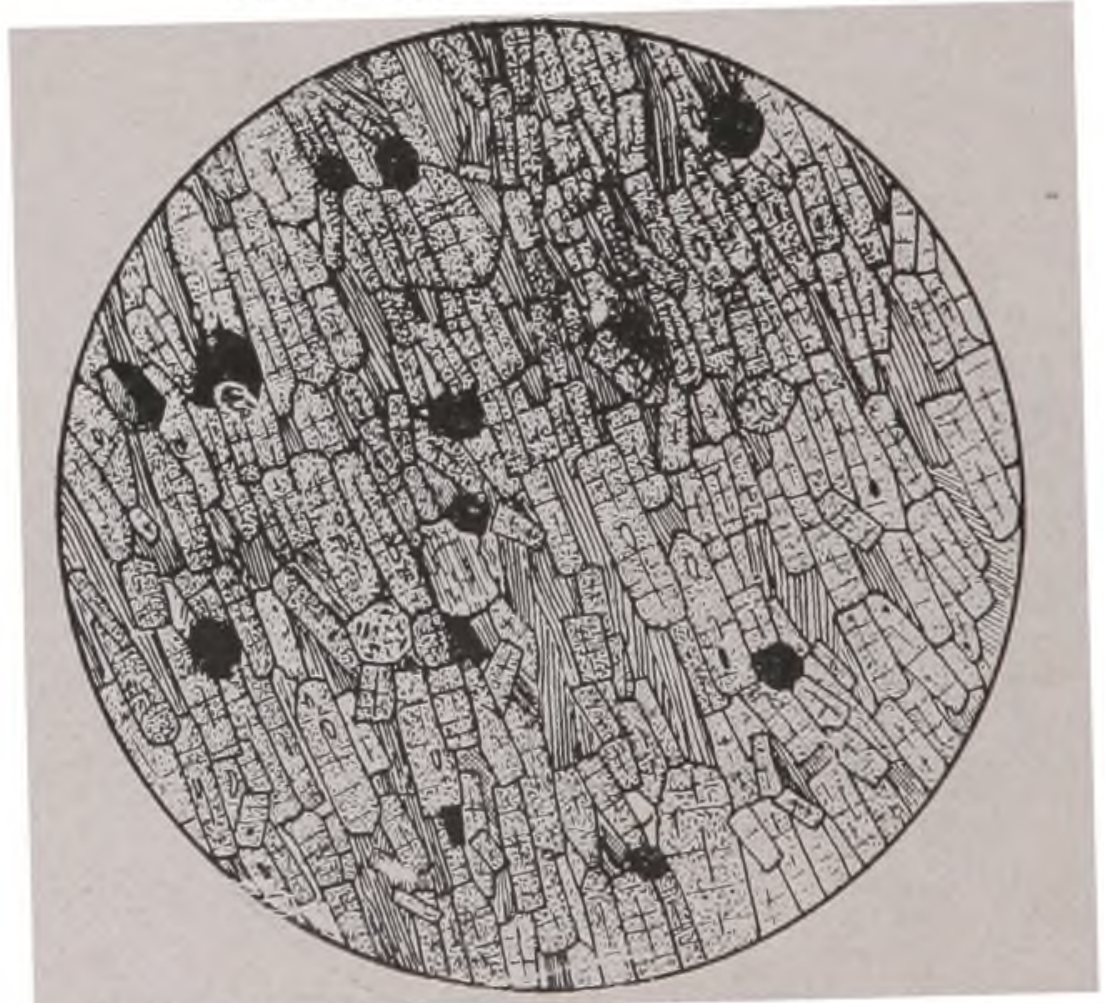

Fig. 27 - Micaxisto fortemente turmalinizado e rico de disseminações de cassiterita, mina de Cerro Branco, mun. de Encruzilhada. Os cristais com traços de clivagem em uma só direção são de muscovita. $\times 26$. 
malinizados. Sómente nas suas fórmas de diques e filões é que se pode notar a presença da turmalina. Nestas áreas o elemento fèmico (biotita) não se altera, não se dando o mesmo com os feldspatos. Neste mesmo processo parece haver formação de quartzo secundário, pois não é raro se encontrarem grãos de quartzo ricos de restos de turmalina e mesmo agulhas dêste mineral.

Finbora não tenhamos encontrado áreas de granitos turmalinizados, somos de parecer que deve ter havido zonas que sofreram auto-pneumatólise endógena após a solidificação desta rocha, pois o magma primitivo devia ter sido muito rico de constituintes voláteis.

Brammal e Harwood (8), no estudo exaustivo que fizeram sobre a turmalinizacão do granito de Dartmoor, referem-se a fenòinenos de auto-pneumatólise (com turmalinização), antes da consolidação final da rocha. Falam os Autores mencionados do processo de subslituição pela turmalina, de plagioclásios que mos tram as partes laterais transformadas em turmalina e o centro formado ainda por plagioclásio não alterado. Tal fato, contudo, não constitue a regra geral nas áreas turmalinizadas da faixa estanifera riograndense, onde a turmalina, habitualmente idiomorfa, parece ter-se formado diretamente das soluções ricas do constituintes voláteis e, menos comumente, pela substituição de feldspatos preformados.

C. Reid e J. S. Flett, citados por Shand (33), esclarecem o caso dos granitos de Cornwall, nos quais a fórma original dos feldspatos está algumas vezes preservada, podendo ser observados. ademais, no campo, todos os estados de transformação do feldspato em turmalina.

Nesse particular faça-se menção ao trabalho de Boney (7). que conclue provir a turmalina microlitica do luxulianito, de ações quimicas sobre os feldspatos, sendo a turmalina produto secundário, formado a partir dos constituintes feldspáticos das várias rochas.

A formação de "greisen" é o segundo fenômeno de importância, que analisaremos a seguir. Pudemos verificar sua formação, principalmente na mina de Campinas, em Pedro Freitas e na ocorrência de Gorita.

Em virtude desta palavra ser usada por diferentes autores para designar coisas diversas, usaremos o termo "greisen" para as formacões quartzo-mica, originadas ao longo das fraturas e fendas do granito, pela alteração de seus minerais primários. mediante processos pneumatolíticos, nos quais desempenham papel de relêvo o vapor de agua, ácido bórico, cloro e flúor. O "greisen" da região apresenta-se com coloração clara e textura variável e a cassiterita, quase sempre presente, ocorre em cristais disseminados na associação quartzo-mica (fig. 28). Além dèstes mi- 
nerais, encontrámos ainda cristais de fluorita violeta, formados talvez pela açào sôbre o feldspato do ácido fluoridrico, originado após a precipitação da cassiterita. Encontrámos também peque-

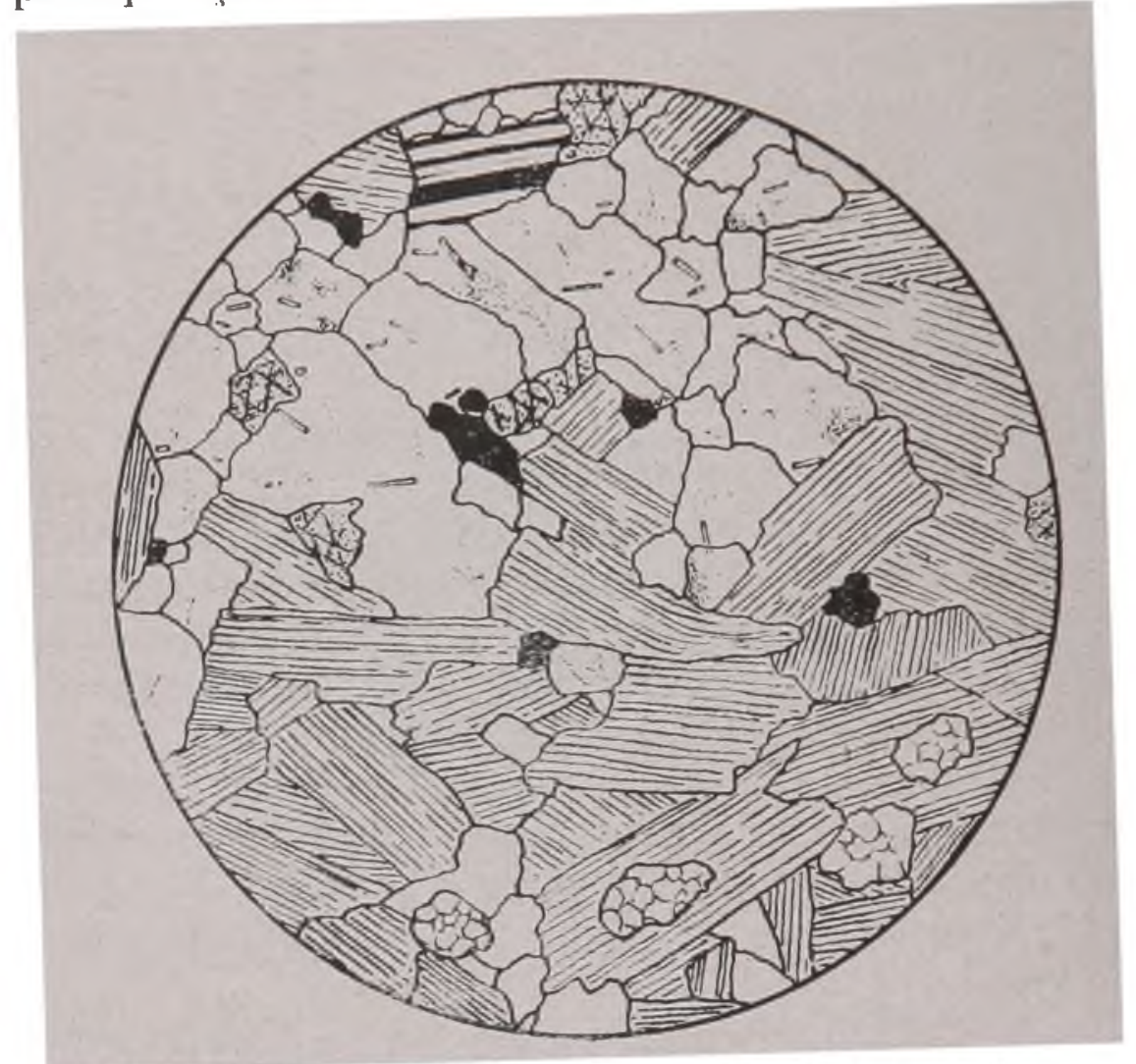

Fig. 28 - Zona greisenficada, jazida Pedro Freitas, mun. de Piratiní. Muscovita (traços de clivagem em uma só direção), quartzo, cassiterita (preto) plagioclásio e fluorita (traços de clivagem em três direções). No interior dos cristais de muscovita veem-se cristais de apatita.

nos, cristais de apatiła, ao passo que poucas vezes deparámos com a turmalina em tais associaçôes.

As áreas dos granitos, que se mostram greisenficadas, são constituidas quase exclusivamente por muscovita (fig. 29). Áreas muscovitizadas apresentam-se quase sempre dobradas e encurvadas indicando, claramente, a existência de movimentos cataclásticos locais durante a intrusão do material formador dos pegmatitos e filões (fig. 30). Não só se verifica completa laminação da muscovita e amarrotamento das lâminas de clivagem, como os cristais de quartzo fornam-se fraturados, com evidente extinção ondulante. Os cristais de cassiterita, por sua vez, mostram-se também fraturados e ricos de traços de clivagem formados durante os mesmos movimentos.

Áreas graníticas menos alteradas possuem ainda restos de cristais de feldspatos que não foram tolalmente substituidos. A grei- 
senficacão observada pelo autor extende-se por faixas não muito largas (de poucos centímetros até meio metro), podendo notar-se que algumas áreas mostram perfeita transição entre o granito

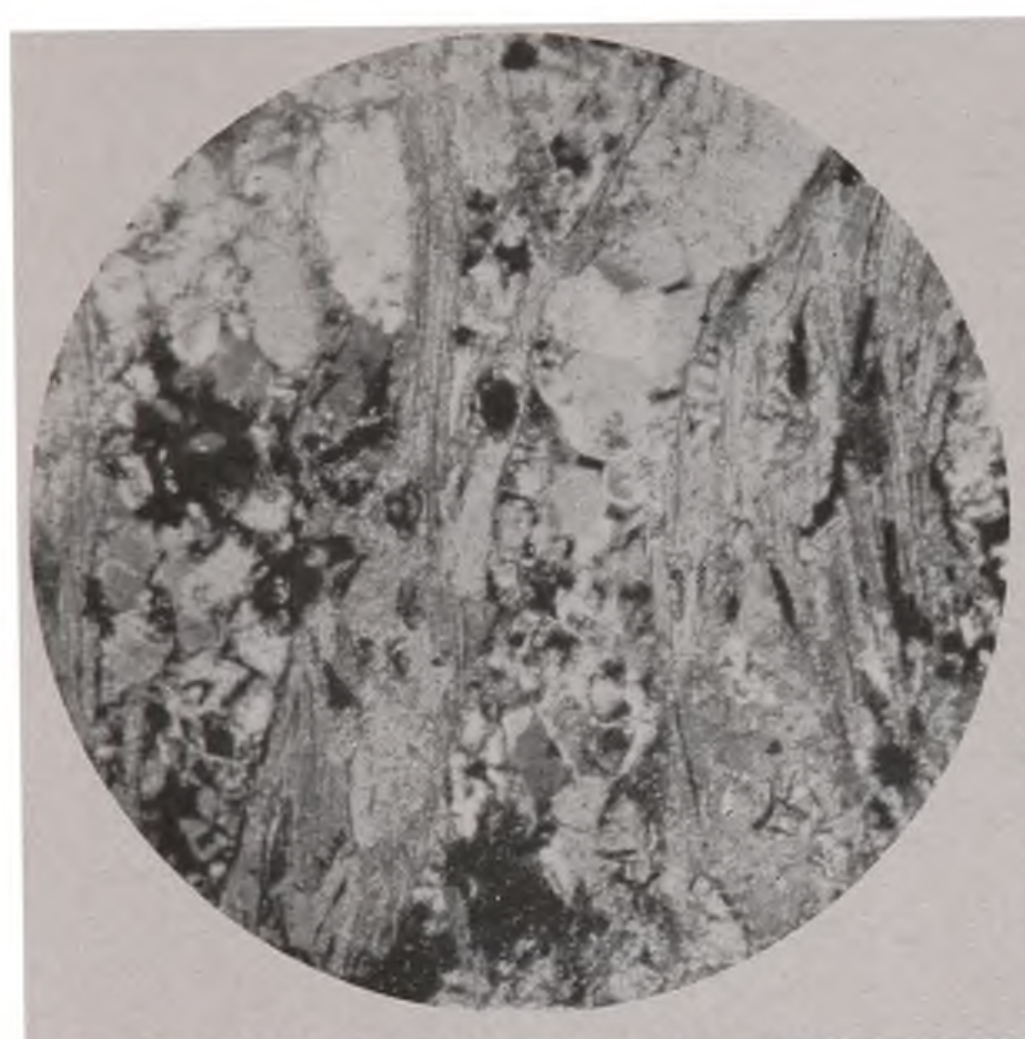

Fig. 29 - Faixa greisenficada, mina Campinas, mun. de Encruzilhada, $\mathrm{N}+\times 35$. Veem-se muscovita, quartzo e cassiterita (preto).

fresco e as zonas alteradas. Na região de Campinas onde ocorrem inúmeros filóes e diques encaixados no granito (stock-work) há zonas, nas quais pouco ou nada do granito originário poude ser observado.

Beger (1) esludando o granito de Ialusitz, descreve tambén que a rocha normal (granito) passa por todos os estádios intermediários até um "greisen" lípico, constituido por quartzo, inicamuscovita, litionita e flogopita.

Weed, citado por Johannsen (21), refere-se, por sua vez, estudando a ucorrência de cassilerila de El Paso (México) que o granito, rocha encaixante dos


Fig. 30-Faixa greisenficada, jazida Pedro Freitas, mun. de Piratini:

1 - Feldspato e quartzo microgranulares

2 - Fluorita

3 - Muscovita

4 - Cassiterita

5 - Cristais aciculares de turmalina. diques de cassiterita, volframita, sc evidencia greisenficado, exibindo perfeita transição para o granito normal. 
Não verificámos a existência de topázio em nenhuma das jazidas nas quais ocorrem áreas greisenficadas ou mineralizadas.

\section{c) Cassiterita}

A cassilerita da área mineralizada apresenta-se, ora nas suas matrizes (pegmatitos, veeiros), ora como material eluvionar e aluvionar. Em Campinas, nos pegmatitos e filóes, predominam os cristais geminados, segundo face de bipirâmide tetragonal de II ordem. Pudemos verificar, em outros pontos da região, eristais simples com hábitus piramidais e bipiramidais. Na Sanga dos Ausentes encontrámos cristais geminados, segundo a lei do rutílio. Não encontrámos em toda região a forma botrioidal e reniforme

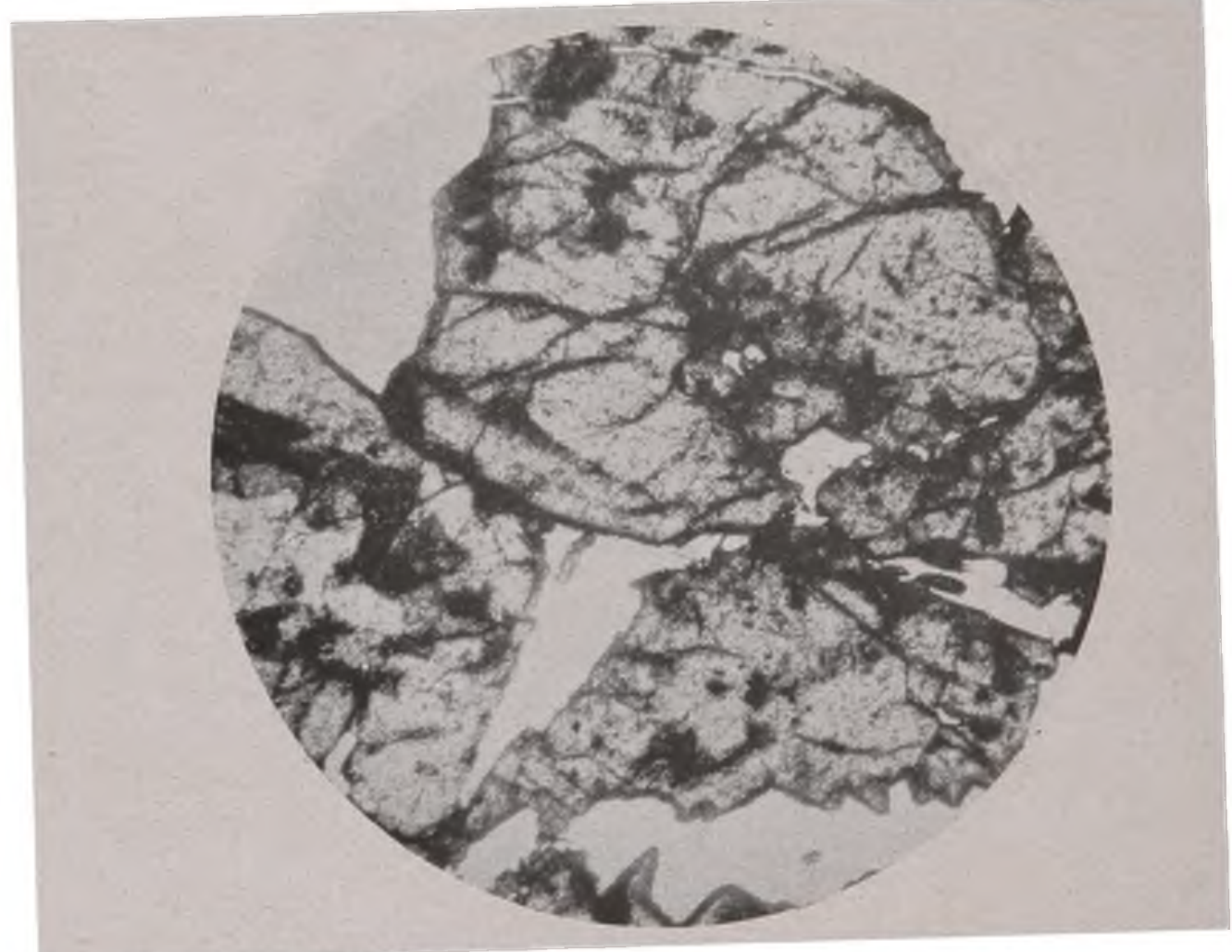

Fig. 31 - Filão de quartzo e cassiterita, jazida Pedro Freitas, mun. de Piratini, L.N. $\times 35$.

(estrutura fibrosa concêntrica), tão comum nos depósitos de Cornwall, Inglaterra e de algumas jazidas chilenas e bolivianas. Sòmente em uma ou outra amostra, pudemos verificar incipiente pseudomorfose da cassiterita sobre os feldspatos. Nào há indicios da existêncja de estanita. Não verificámos também a existc̀ncia dos boratos de estanho, nordenkjöldila, hulsitg e paigeita, encontrados nos depósitos do Alaska.

A cassiterita apresenta-se em cristais de tamanhos variados. desde fómas microscópicas até amostras de muitos quilos. A co- 
Loração é geralmente escura, havendo, entretanto, depósitos ricos de cassiterita semi-transparente e mesmo transparente. Os cris-

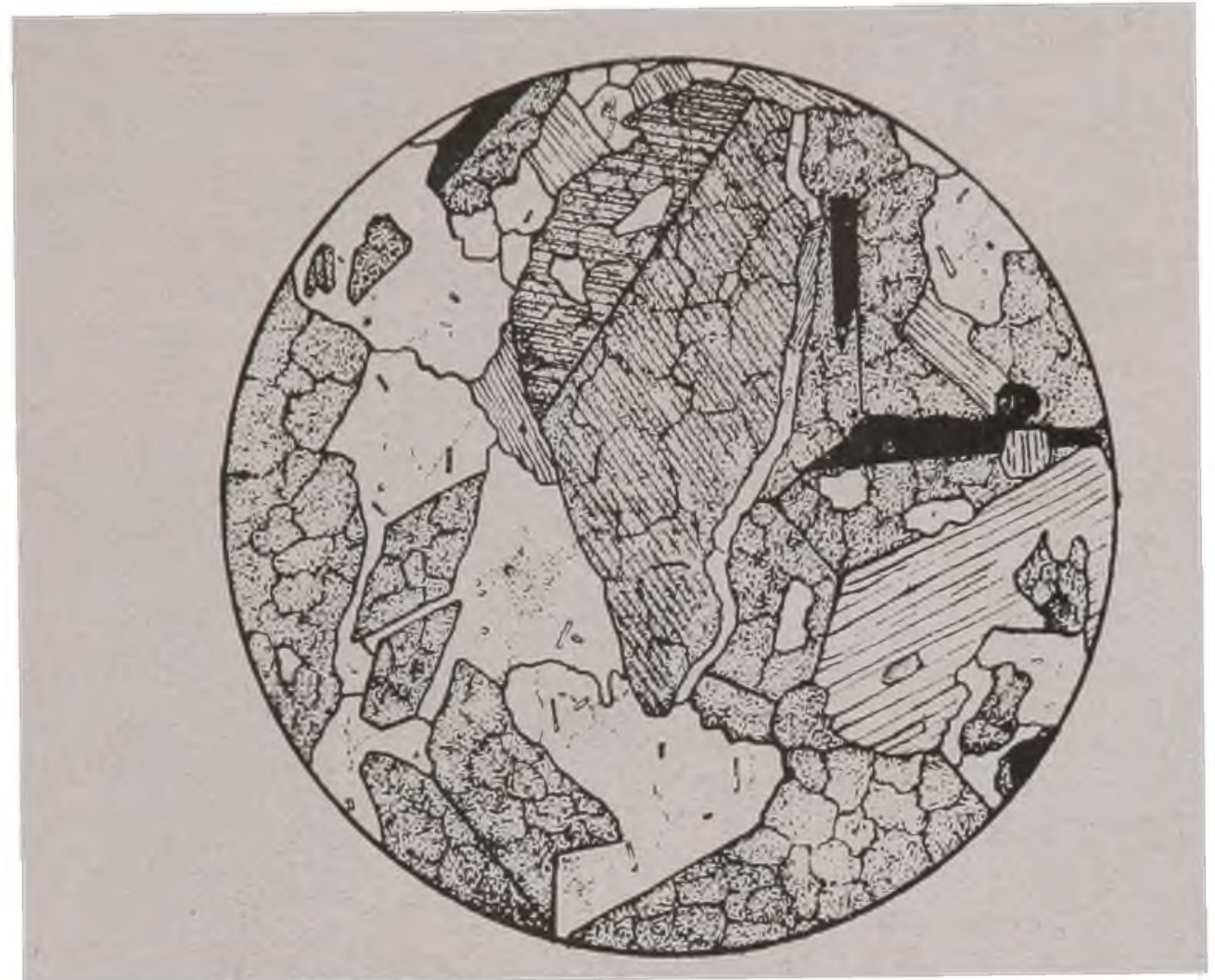

Fig. 32 - Filâo de quartzo rico de cassiterita, jazida Pedro Freitas, mun. de Piratini. L.N. $\times 26$.

Notar cristais de cassiterita geminados, quartzo e muscovita (traços de clivagem).

tais grandes apresentam-se comumente fraturados, o que nos leva a admitir a existência de movimentos tectónicos durante e após a formação da cassiterita (fig. 30).

\section{d) Aplitos e pegmatitos}

Os pegmatitos da regiāo mineralizada são de composição mineralógica relativamente simples. Considerando, entretanto, que há sempre algumas pequenas diferenças entre êles, serão descritos e interpretados isoladamente, posto que nenhum dêles pode ser tido como padrão.

Os componentes essenciais são - ortoclásio, microclínio, oligoclásio e quartzo e os acessórios - cassiterita, turmalina e muscovita.

A estrutura dos diques pegmatíticos mostra dois tipos principais de simetria. Existem os que são de simetria bilateral e os inteiramente assimétricos. Alguns teem como rocha encaixante o próprio granito, outros, os xistos. 
Neste trabalho, o termo pegmatito não será usado para formações graníticas de textura gráfica mas sim para as rochasdiques de textura granular grosseira, produtos finais da intrusão granítica. Aplito significará, aqui, elementos em fórma de diques. de textura fina, com escassa ou nula quantidade de minerais escuros, textura sacaróide (aplítica) e constituidos mineralògicamente por quartzo e feldspato potássico. Pegmatitos e aplitos acham-se quase sempre associados, parecendo haver entre ambos estreitas relações de origem.

\section{Aplitos}

Foram observados principalmente nas áreas já denudarlas do granito e nos grandes matacões (boulders) encontrados nas margens do Rio Camaquan, (fig. 21) A espessura varia consideràvelmente, sendo entretanto mais comuns os de 5 a $15 \mathrm{~cm}$. Exibem em geral textura fina e são, de regra, de coloração esbranquiçada (ortoclásio, microclínio e quartzo), mostrando certa quantidade de turmalina. Aparecem ainda, embora mais raramente, lâminas de muscovita e, lambém, muscovita epigenćtica. Contudo, êstes diquies atravessam também os xistos encaixantes. Não foi verificada a presença de cassiterita nos aplitos. aplitos.

Damos abaixo a seguir o resultado da análise de um dêsses Aplito -. Arroio das Pedras

$\begin{array}{llc}\mathrm{SiO}_{2} & \cdots & 74,12 \\ \mathrm{P}_{2} \mathrm{O}_{5} & - & 0,28 \\ \mathrm{TiO}_{2} & - & \text { traços } \\ \mathrm{Al}_{2} \mathrm{O}_{2:} & - & 13,92 \\ \mathrm{Fe}_{2} \mathrm{O}_{3} & - & 2,05 \\ \mathrm{MgO} & - & 0,44 \\ \mathrm{CaO} & -\cdots & 0,18 \\ \mathrm{Na}_{2} \mathrm{O} & - & 4,55 \\ \mathrm{~K}_{2} \mathrm{O} & - & 4,16 \\ \mathrm{H}_{2} \mathrm{O} & - & 0,78 \\ & & 100,48 \%\end{array}$

(Analisla -- Paulo Mathias)

P. esp. 2,64

Pegmatitos

Os pegmatitos são numerosos nas margens do granito intrusivo e mais ainda nas áreas xistosas, que cobrem aquela rocha. 
Não verificámos a presença de pegmatitos e aplitos nos quartzitos e másmores cristalinos, nem mesmo nos pontos onde se nota intimo contacto destas rochas com o granito intrusivo.

As primeiras concentraçós de cassiterita se formaram durante a cristalização dos pegmatitos primários. Contudo, há raazões para se acreditar que o volume total dos pegmatitos deve ter sido aumentado, principalmente pela deposição de material novo, por efeito das solucões.

A fig. 33 nos dá idéa da associação mais comum encontrada nos pegmatitos, quando èstes se acham como diques encaixarlos

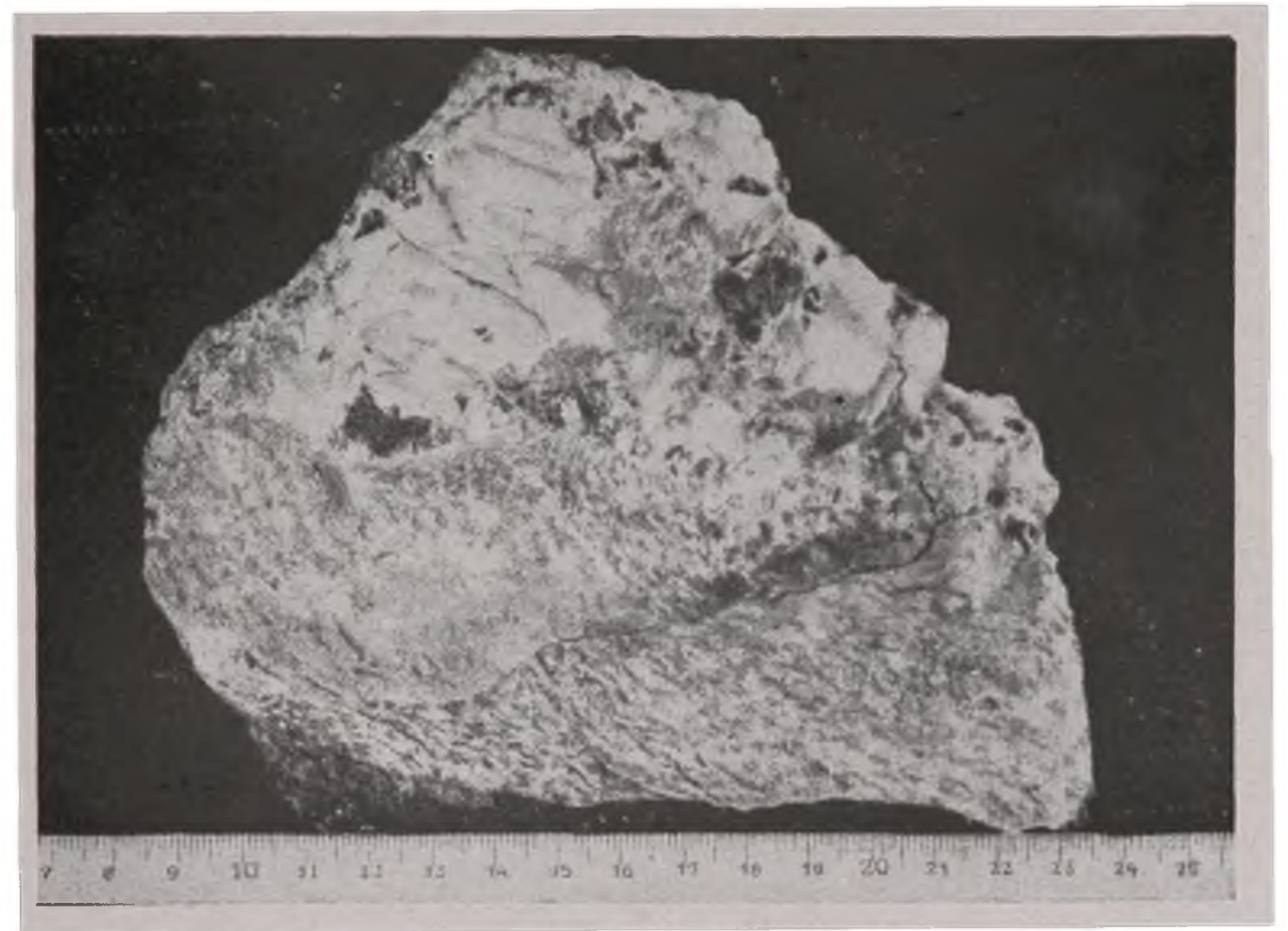

Fig. 33

nos granitos. Partindo-se de baixo para cima encontra-se o muscovita-granito não alterado que passa, mais ou menos bruscamente, para faixa completamente muscovitizada e laminada, onde ainda podem ser notados restos de feldspatos e quartzo. não totalmente substituidos pela mica. Sempre nesta faixa, encontramse, não muito comumente, turmalina e pequenos cristais de cassiterita. Esta muscovitização, comum na maioria dos pegmatitos da mina de Campinas, passa a faixas inteiramente greisenficadas, nas quais a turmalina e a cassiterita estão quase sempre presentes. A constante e intima associação da cassiterita e turmalina nos leva a admitir que êstes dois minerais se tenham depositado contemporâneamente.

Na mesma fotografia vè-se que, logo acima da zona, onde predomina a muscovita e sericita secundárias, existem cristais de mi- 
croclinio, cristais informes de quartzo, mica formada diretamente no pegmatito e cristais de cassiterita relativamente grandes. ....

Este dique mostrava-se perfeitamente simétrico e com espessura de cerca de 30 centimetros.

Não há textura micropegmatítica ou gráfica e a distribuição dos minerais no seu interior não exibe sinal algum de estratificação.

A fig. 3t, Mina Paulista, representa um tipo de pegmatito inteiramente diferente do precedente. Aquí, a rocha encaixante é constituida pelos xistos. Sua estrutura é assimétrica, notando-se mesmo que a formacão de turmalina se localizou apenas em uma

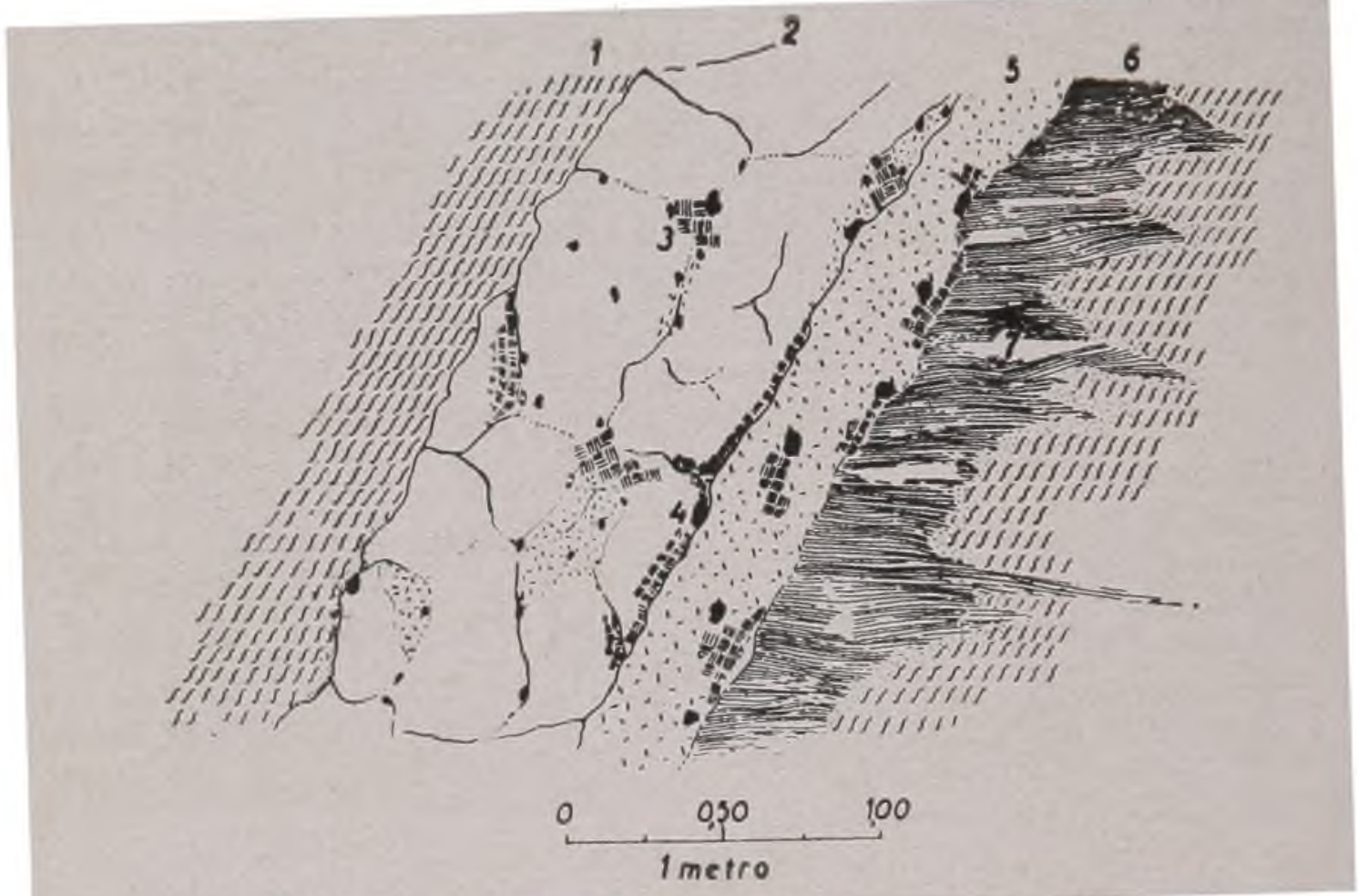

Fig. 34 - Pegmatito, mina Paulista, municipio de Piratini.
1 - Micaxistos
2 - Quartzo
3 - Muscovita
4 - Cassiterita
5 - Feldspato
6 - Turmalina impregnando o micaxisto
7 - Quartzo residual.

las paredes da rocha encaixante. Pode notar-se também que, mesmo aquí, existe muscovitização nas zonas de contacto. Ao contrário do pegmatito precedente, no qual o quartzo encontrado se apresentava como pequenos cristais informes, aquí, êste mineral forma grandes massas cristalinas, na maioria das vezes fraturadas. A cassiterita acha-se disseminada não sòmente na massa de feldspato mas também no quartzo. O feldspato já se mostrava 
bem alterado e transformado em caolim, o qual comumente é conhecido entre os garimpeiros pelo nome de "massa branca". Intimamente associado ao quartzo encontram-se regiões ricas de feldspato e mica. Aqui. o que se deu foi aparentemente o seguinte: primeiramente, formou-se pequeno dique pegmatítico constituido por feldspato, quartzo, muscovita e cassiterita, o qual sofreu a intrusão de soluções aquosas finais, ricas de sílica que ao atravessarem o dique pegmatítico, localizaram-se na zona de menor resistência. Finalmente, com a ascenção das soluções ricas de vapor de agua e agentes mineralizadores, através do pegmatito já modificado anteriormente, deu-se a reprecipitação de cassiterita e turmalina ao longo das fraturas do pegmatito e planos de xistosidade do xisto.

Pode-se notar também que os minerais se mostram fraturados e com extinção ondulante devido às deformações mecànicas. provocadas pelos esforços das diferentes ascenções.

Em conseqüência, concluimos que deve ter havido, após e durante a formação dos pegmatitos, acentuada influência de soluções e elementos voláteis através das fraturas e fendas, com formação de minerais de origem hidrotermal e pneumatolítica.

A fig. 35, representa dique originàriamente constituido por feldspato, quartzo, muscovita e cassiterita, o qual foi influencia-

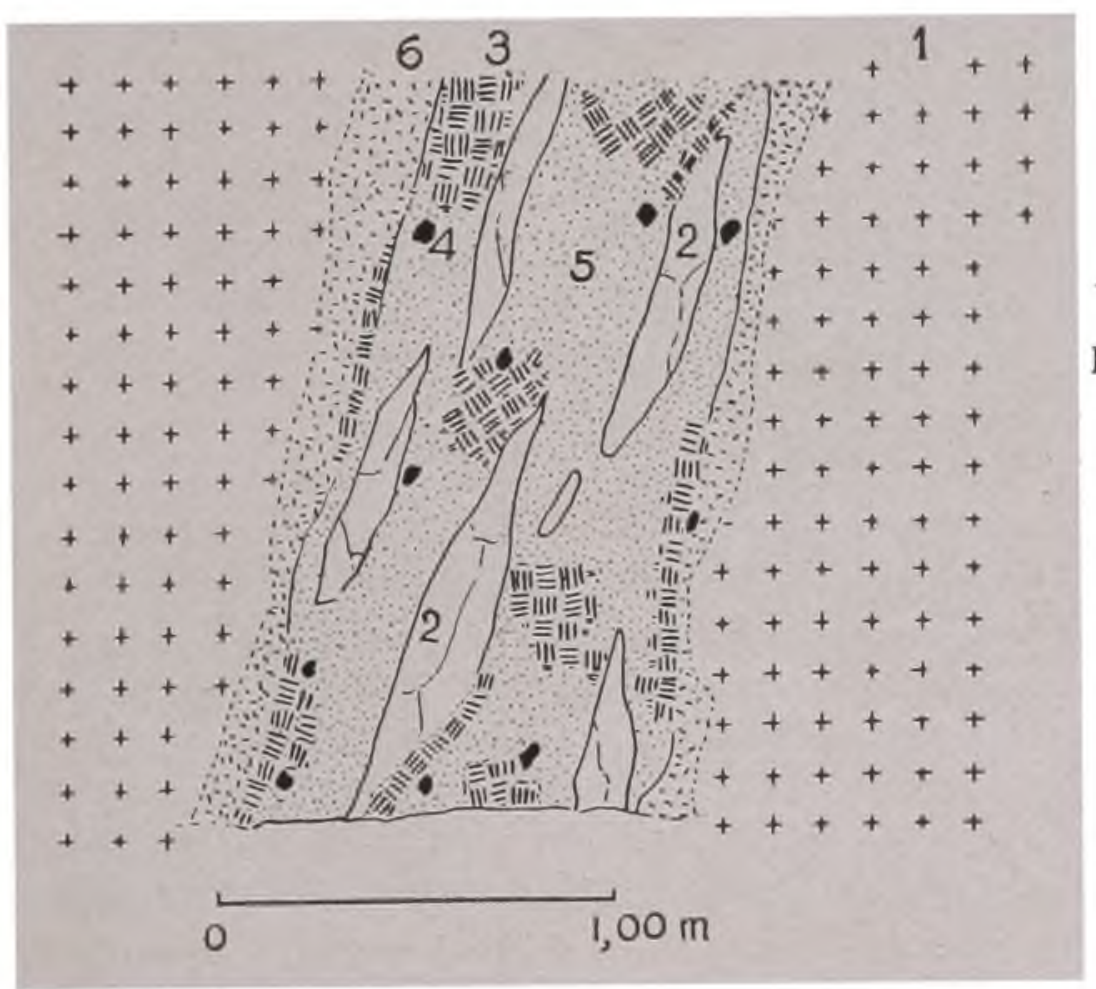

Fig. 35 - Dique pegmatitico, mina Campinas, mun. de Encruzilhada.

1 - Granito encaixante

2 - Lentes de quartzo

3 - Muscovita

4 - Cassiterita

5 - Feldspato

6 - Granito alterado.

do pelas soluções aquosas ricas de sílica. Parece não ter havido neste caso, migração alguma do material originário do dique bem como substituições apreciáveis. 
Na fig. 36, nota-se que as paredes do granito encaixante estão totalmente greisenficadas. O interior do dique mostra também grandes lentes de quart $\%$ informe. No interior do quartzo veem-se massas inalteradas de feldspato e mica que não sofreram a ação



Fig. 36

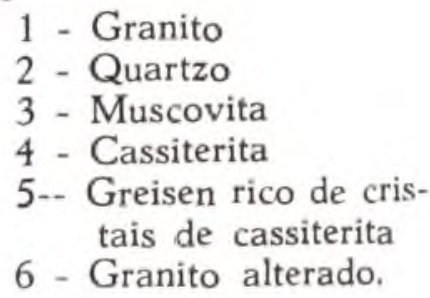

dos agentes voláteis e das soluções. Nota-se ainda grande concentração de cassiterila nas zonas greisenficadas. Como se vê pelo desenho, as alterações das paredes do granito não se verificaram em grande profundidade, mas $\operatorname{sim}$ em áreas bem restritas.

Fig. 37 - Pegmatito, mina Campinas, municipio de En cruzilhada.

$$
\begin{aligned}
& 1 \text { - Granito } \\
& 2 \text { - Quartzo } \\
& 3 \text { - Muscovita } \\
& 4 \text { - Cassiterita } \\
& 5 \text { - Feldspato } \\
& 6 \text { - Granito alterado. }
\end{aligned}
$$

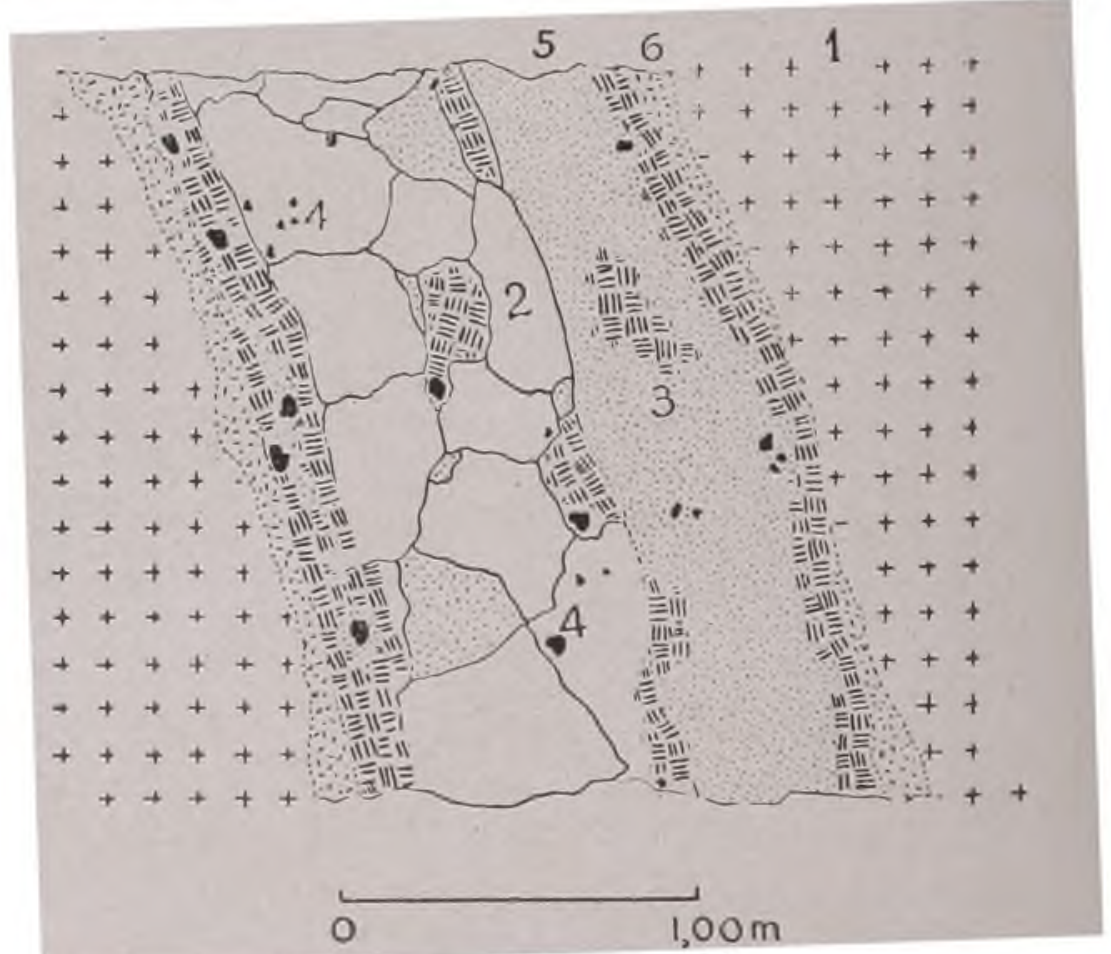

Na fig. 37 (Campînas), a estrutura do dique é assimétrica mas a interpretação é a mesma dada para os outros exemplos. 
Contudo, o que se pode notar neste caso é intensa e simétrica muscovitização nas zonas de contacto.

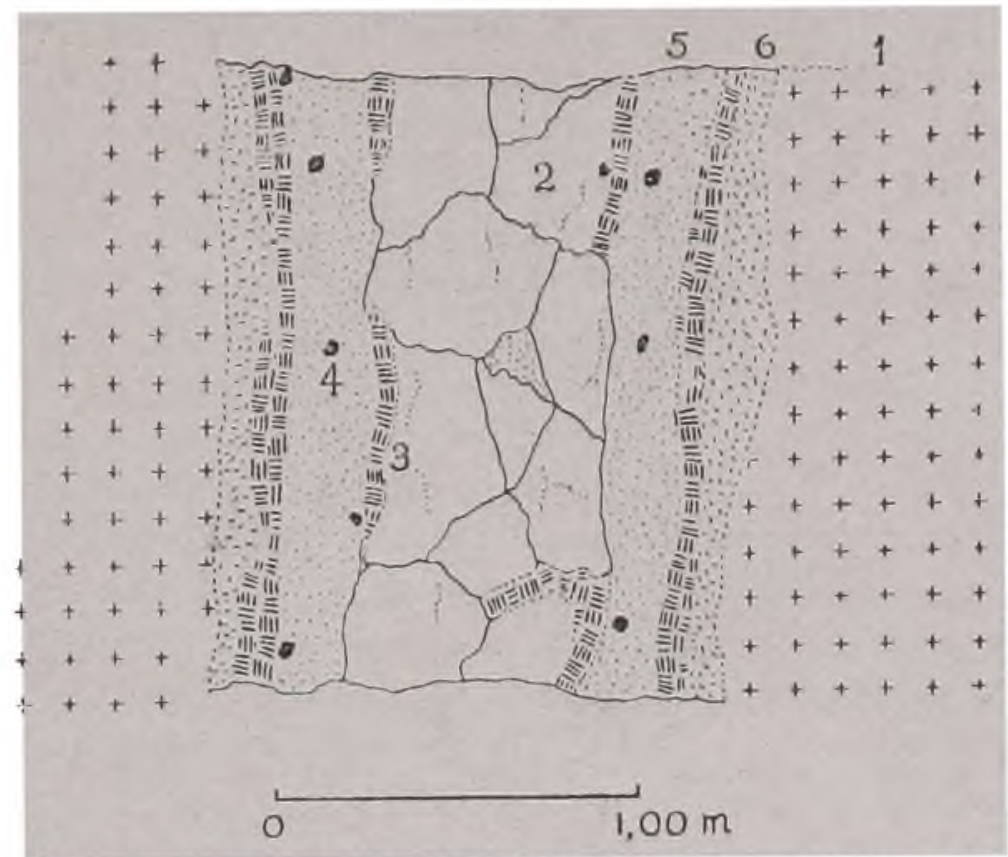

Fig. 38 - Pegmatito, jazida Pedro Freitas, mun. de Piratini .

1 - Granito

2 - Quartzo

3 - Muscovita

4 - Cassiterita

5 - Feldspato

6 - Granito alterado.

A fig. 38 (Pedro Freitas) representa dique-pegmatito simétrico, mergulhado verticalmente. Notar o desenvolvimento de muscovita nas paredes externas do pegmatito e na zona de alteração do granito encaixante.

\section{e) Filões}

Ao lado dos pegmatilos encontra-se grande número de filões formados quase exclusivamente de quartzo e contendo como minerais de associação, a muscovita, a cassiterita e muito raramente a molibdenita. Nota-se em quase todos êles, a tendência do quartzo no sentido de se cristalizar nas partes centrais dos filozes. ficando a massa de sílica, extremamente pura, quase sempre compreendida por faixas de mica e, ocasionalmente, feldspatos.

Pudemos verificar em alguns casos perfeita transicão entre os diques de pegmatilos (geraimente influenciados pelas soluções ricas de sílica) e os veeiros de quartzo.

Esta passagem gradual de pegmatitos e veeiros de quartzo tem sido objeio de estudo por parte de muitos mineralogistas, 
principalmente quando se procura evidenciar a importância dos agentes mineralizadores nas suas formações. Brögger (9), Sederholm (32), Tolman (36), Emmons (14) e muitos outros se destacam neste campo de investigações.

Em muitos casos, us veeiros de quartzo são paralelos e concordantes com as estruturas da rocha encaixante; existem, porém, veeiros que cortam discordantemente estas rochas. Os veeiros são encontrados geralmente nas rochas encaixantes, nos diversos tipos de xistos e acham-se, de regra geral, em niveis diferentes aqueles dos pegmatitos.

Os inúmeros veeiros estudados também não mostram sinais de estratificação dos minerais e raramente encontrámos drusas ou geodos. Há, contudo, quase sempre, perfeita associação entre o quartzo e a turmalina, sendo rarissimos os veeiros de quartzo que não se mostram turmalinizados. Em alguns lugares, notam-se numerosas concreçôes aciculares de turmalina azul-acinzentada distribuidas erráticamente pela massa informe de quartzo.

Nos filōes pudemos verificar também a formação de turmalina em uma das paredes do veeiro, enquanto a outra permanece perfeitamente livre da turmalinização. Tal distribuição assimétrica, visível às vezes em lâminas petrográficas, não constitue fato peculiar da região, porquanto muitos autores, se referem ao mesmo fenòmeno. Entre êles, P. K. Chosh (16), no trabalho que realizou sobre o granito de Bodmin Moor em Cornwall.

A fig. 39, representa filão típico, tal qual foi descrito aiteriormente. Este foi um dos únicos filões onde verificámos a exis-



Fig. 39 - Filão quartzifero, mina Cerro Branco, mun, de Encruzilhada.

1 - Micaxisto

2 - Quartzo

3 - Muscovita

4 - Cassiterita

5 - Lâminas de molibdenita

6 - Turmalina impregnando o micaxisto encaixante.

tência de molibdenita associada à cassiterita. Notar na figura a faixa turmalinizada que substitue larga área do xisto encaixante, bem romo a distribuição simétrica dos elementos dos filões. 
Com relação à presença de molibdenita, desejamos pedir a atenção do leitor para o fato seguinte: W (r. R. Camargo (comunicação verbal), que estudou a jazida de molibdenita de Vacacai (Rio (irande do Sul), conclue que o aludido depósito é do tipo hipomesotermal, resultante de atividade magmática granitica na zona de contacto com os xistos cristalinos da série Porongos. Considerando que lá, o depósito se formou também por influência de intrusões graníticas, encaixadas nos termos metamórficos da série Porongos, tal qual sucede com os fenomenos por nós verificados na $f$ a i $x$ a e st a n íf e $r$ a, somos de parecer que a mineralizacão do depósito de molibdenita de Vacacaí e a dos municípios de Encruzilhada-Piratini devem ter pontos de contacto no que diz respeito à gênese e à idade. Há, contudo, entre as duas regiões mineralizadas -- Vacacai e Encruzilhada-Piratiní - a!guns pontos bem distintos. Na primeira área, aquele Autor não verificou nem fenomeno de turmalinização nem formação de "greisen" na região de contacto do filão com a rocha encaixante, fato tão comum nos depósitos estaníferos da segunda área. A grande quantidade de sulfêtos hipógenos e supérgenos e a ausência de cassiterita, segundo verificou W G. R. Camargo, constituem o outro principal e característico distintivo das duas áreas. Muito provàvelmente, as intrusões graníticas de ambas áreas, embora tenham ocorrido no mesmo período - - algonquiano - parecem não provir da mesma fonte, devendo ser considerados ou como duas intrusões distintas ou como depósitos formados pelo mesmo magma mas em condicóes de temperatura, pressão e concentração diferentes e níveis, provàvelmente diversos.

A fig. 10) representa um estreito filão de quartzo intensamente turmalinizado onde não há, entretanto, cassiterita. A parte ponteada é composta de quartzo e ortoclásio róseo.

Do estudo dos pegmatitos, aplitos e filóes devemos concluir que houve durante a formação de tais rochas dois processos bem ristintos, embora nem sempre estejamos habilitados a perceber exatamente quando comeca um e onde termina o outro. Qualquer que seja o tipo de corpo mineralizado que consideremos, distinguimos o processo magmático e o processo pneumatolíticohidrotermal. No primeiro, ter-se-iam formado os pegmalitos e aplitos de composição mineralógica aproximadamente idèntica àquela da rocha de origem. Neste processo, sistema essencialmente fechado, os diferentes minerais ter-se-iam originado diretamente do mágma, cuja fluidez seria devido, única e exclusivamente, à temperatura própria da massa fundida. A esta fase. seguiu-se o processo pneumatolítico-hidrotermal, no qual a mobilidade dos diferentes materiais se deve à presença, principalmente, do vapor d'água. Originam-se neste segundo periodo de pre. cipitação, minerais novos que não constituiam elementos do 
mágma originário. Assim, a formação da albita, quartzo, turmalina, cassiterita, muscovita, fluorita, sericita e outros minerais dificilmente identificáveis, resultou das modificações de equilíbrio e das variadas relações de estabilidade durante o processo pneumatolítico-hidrotermal, sobre o material magmático consolidado ou em via de consolidacão. Muitos autores entre êles Thad G. McLaughlin (28), K. K. Landes (22) e N. M. Uspensky (37), esposam também esta leoria, segundo a qual processa-se sempre substituição, bem visivel, de minerais primários por minerais secundários, pela influència de agentes mineralizadores.

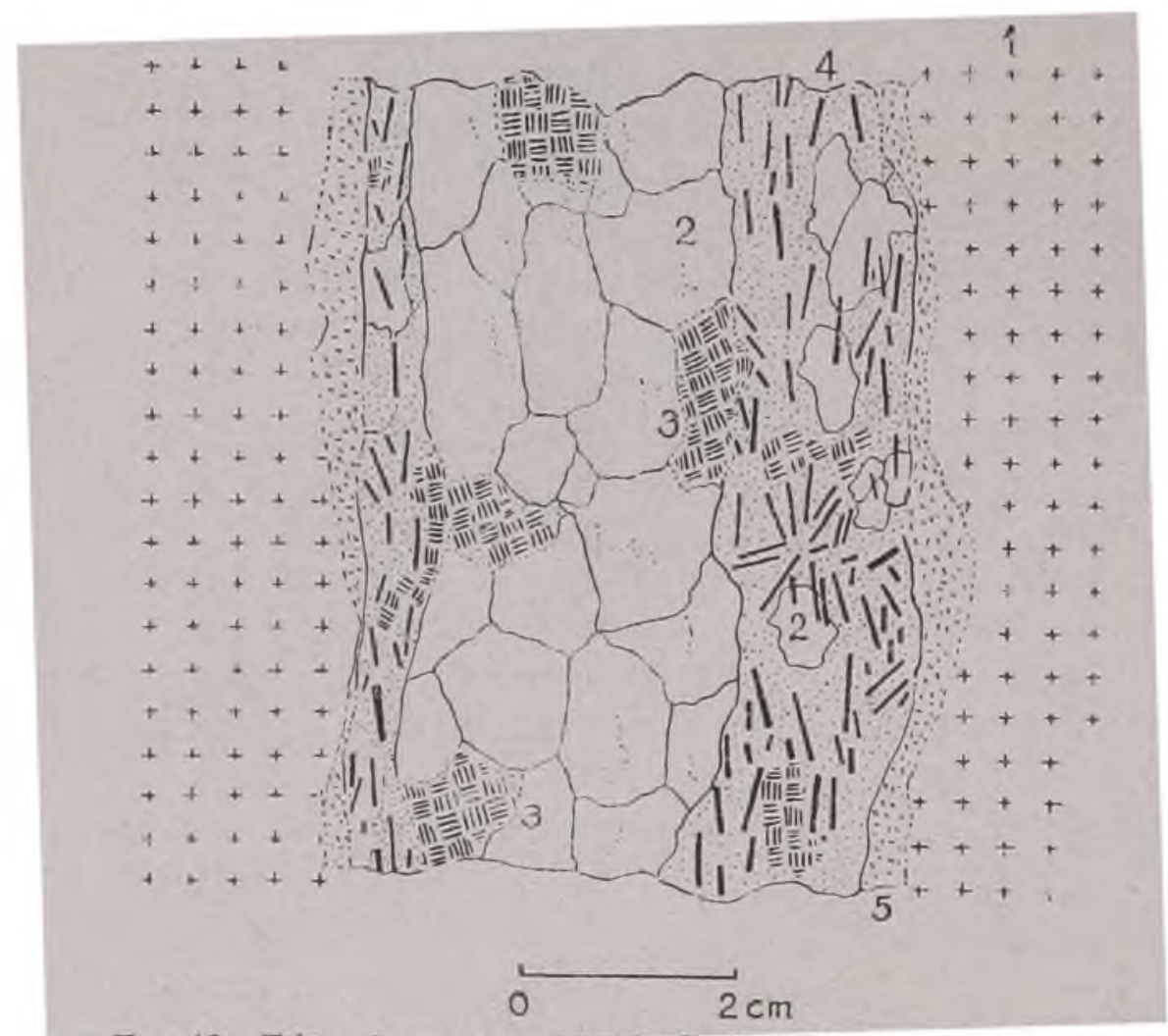

Fig. 40 -Filão de quartzo, jazida Pedro Freitas, municipio de Piratini:

1 - Granito

2 - Quartzo

3 - Muscovita

4 - Feldspato e quartzo rico de cristais aciculares de turmalina

5 - Granito alterado.

Dêste modo, pegmatitos e aplitos de composição mineralógica relativamente simples, após os efeitos do processo pneumatolitico-hidrotermal, tornaram-se mais complexos com a formação de grupos de minerais ou novos minerais.

Finalmente, com a ascenção das soluções residuárias epitermais, resultantes ainda do processo magmático que se estabeleceu com a intrusão do granito, verificou-se a formação de faixas caoli- 
nizadas e sericitizadas. Fsta alteração não alinge sòmente os pegmatitos e filões mas lambém, e principalmente, as diaclases do granito.

Schaller (31) acha mesmo que, durante o processo magmático, formar-se-iam sòmente feldspato potássico, pequena quantidade de feldspato sódico e porcentagem minima de quartzo. Os outros minerais originar-se-iam sòmente na fase hidrotermal.

A seqüência na ordem de cristalizacão dos minerais de origem pneumatolítico-hidrotermal, a partir dos minerais originàriamente formados, nem sempre foi de fácil verificação quer no campo como no laboratório.

Outro fato para o qual desejamos pedir a atencão dos leitores é aquele que diz referência à composição dos filões e pegmatitos por nós estudados. Ao contrário do que se observa em outros depósitos de cassiterita, a faixa estanífera riograndense apresenta composição mineralógica bem simples (fig. 41). Nesta figura, amostra tirada das paredes externas de um pegmatito, vê-se a disseminação de cristais de cassiterita (preto) na massa de feldspato-quartzo microgranular. Vê-se, também, cristais bem desenvolvidos de microclinio e disseminação de cristais de muscovita. Aí, em ponto algum, pudemos encontrar associações de minerais que se comparassem aos depósitos de outras localidarles. Assim, não verificámos a existência de cassiterita com pirita, blenda, arsenopirita, siderita, apatita e topázio, tão comuns nos depósitos filonianos de Freiberg (Saxônia) e Sullivam mine (Columbia Britânica). Nem mesmo os já conhecidos depósitos filonianos de volframita de Cerro d'Arvore e Sanga Negra - parte norte da faixa estanifera riograndense - mostram qualquer analogia de paragênese com os pegmatitos e filóes estudados pelo autor.

Fm Cornwall, Inglaterra, a paragênese é inteiramente diversa, porquanto lá, os depósitos de cassiterita são mais complexos: os elementos paragenéticos compreendem quartzo, clorita, cassiterita, volframita, estanita, molibdenita, calcopirita, pirita e blenda; na Bolívia, são representados pelos seguintes minerais: clorita, Iurmalina, apatita, quartæo, cassiterila, pirita, calcopirita, arsenopirita, estanita e prata.

Ramdohr (30) em seu trabalho sol)re os depósitos estaniferos de Arandís, cita o caso de filões (pipes), contendo cassiterita cortando mármores pre-cambrianos. Nessa região, a associação paragenética é muito complexa, pois se encontram pirrotita. axinita, escapolita, danburita, cloretos e fluorita, além de muitos uutros. Esse Autor verifica também que o quartzo é muito abundante, sendo encontrado geralmente nas partes centrais dos filões, tal qual acontece com os filóes e pegmatitos da faixa estanifera dos municipios de Encruzilhada e Piratiní. 
Os depósitos de cassiterita do distrito de Zeeham. noroeste da Tasmânia, mostram por sua vez a seguinte associação: cassiterita, turmalina, calcopirita, galena, blenda, pirita e estanita. No Japão, na região de Akenobe a associacão paragenética é a que se segue: cassiterita, volframita, cassiterita, calcopirita e blenda.



Fig. 41 - Parte de um pegmatito, mina Campinas, mun. de Encruzilhada. (Notar os grandes cristais idiomorfos de microclinio).

1 - Feldspato e quartzo granulares

2 - Muscovita

3 - Cassiterita

Para os estudos de confronto de paragênese citam-se os trabalhos de L. de Launay (13), Beyschlag-Krusch-Vogt (5), W. E Emmons (15) e Alan M. Bateman (3).

Em Itupeva (São Paulo), nos filões de quartzo ricos de volframita ocorrem cassiterita, calcopirita, fluorita e topázio além de blenda, pirita, calcopirita, epidoto, etc. 
Molibdenita foi o único sulfêto que encontrámos em íntima relacão com a cassiterita. Mesmo assim, êste mineral foi encontrado sòmente na mina do Cerro Branco, em um dos filóes de quartzo (fig. 39).

O fato de termos enconitrado filões hidrotermais de natureza tão simples, não significa, obrigatóriamente, que tenham sido, diferentes dos outros mencionados. Os filões estudados poderiam ter sido, originàriamente, tão complexos como os encontrados em outras jazidas, nas quais se nota paragênese muito rica de sulfêtos variados. No Rio Grande do Sul, com a erosão progressiva desde o algonquiano (época na qual se formaram os filões da região), provàvelmente as zonas ricas de sulfêtos, formados em condições de p.t. mais baixo, teriam sido erodidas e transportadas, ficando expostas as zonas mais profundas (zona de contacto dos xistos e granitos), ricas somente de cassiterita.

\section{Conclusões}

As rochas mais antigas que compõem a maior parte da área mineralizada, que acabámos de descrever, são de dois tipos principais: xistos - quartzitos e granitos. Ambos êsses termos pertencem à série Porongos (algonquiano inferior). A formacão mais recente constitue a chamada série Camaquan e é formada por arenitos vermelhos e arenitos arcosianos (devoniano?). Testemunhos desta formação foram encontrados somente en dois pontos da área mineralizada - na região de Taboleiro e nas margens do Arroio Campinas.

O granito intrusivo parece ter sofrido visivel difercnciação magmática, a partir de biotita-granito, com a formação de zonas diferenciadas e distintas, sem contudo constituirem auréolas concêntricas (6).

A diferenciação se opcrou, provàvelmente em conseqüiência das infiltracões magmáticas através do granito em formação, produzindo três tipos principais de áreas diferenciadas, as quais mostram contudo muitos pontos de contacto:

a. núcleo granítico primitivo rico de biotita lúnico elemento ferro-magnesiano) e essencialmente livre dos constituintes voláteis responsáveis pela formacão da turmalina e cassiterita.

b. zona intermediária constituida de granito a duas micas (biotita e muscovita) de textura variável.

c. área constituida por muscovita-granito rico de pegmatitos, aplitos, filões quartziferos, encontrada na parte superior da intrusão, na qual se processou em larga escala, a ação dos constituintes voláteis 


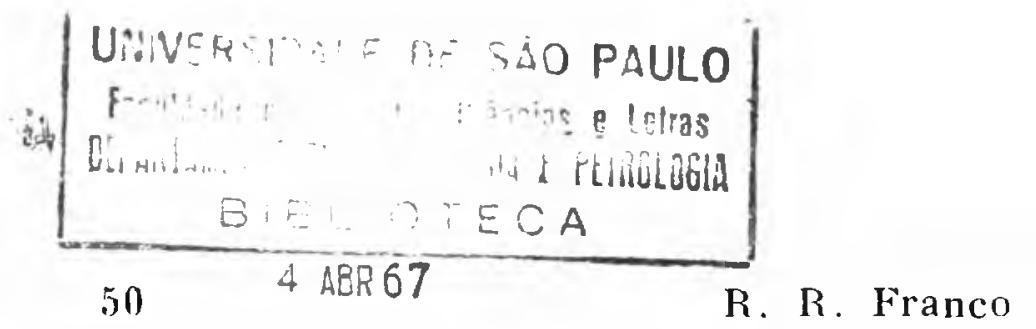

Finalmente, mencionemos ainda, com relação às manifestacões finais da intrusão ácida, a ocorrência de largas e extensas zonas turmalinizadas, que se localizaram de preferência nos xistos e quartzitos encaixantes.

A cassiterita ocorrendo principalmente nos pegmatitos e filoes quartzo-estaníferos e sol) forma inteiramente caótica (distribuição errática) nos leva a concluir que a sua formacão deve ter sido causada por agentes mineralizadores (vapor d’água, flúor, cloro e ácido bórico) os quais atravessaram e substituiram os minerais dos pegmatitos a aplitos. Neste processo originaram-se também faixas greisenficadas, allamente muscovitizadas com apreciável disseminação de cassiterita.

Considerando os resultados a que chegou Georges Soubotian no seu trabalho: "Consideraçôes sobre o problema da exploração dos aluviões eslaniferos das margens do Rio Camaquan. entre Paredão e Pocos dos Dourados, no municipio de Encruzilhada e no 3. Distrito do municipio de Piratiní, Estado do Rio Grande do Sul" publicado na revista Indústria e Técnica, $n .^{\circ} 4$, ano $5 .^{\circ}$ agosto de 1913, que apresentam, em alguns pontos, semelhanca com as observações por nós realizadas na faixa estanífera, resolvemos adicionar, no capitulo das Conclusões, algumas de suas observações e idéias.

Em seu trabalho, o Prof. Soubotian trata não somente do estudo geolrigico de algumas das jazidas, dos diques pegmatíticos e veeiros cutuartzosos bem assim da mineralização em geral. mas também da qualidade dos minerais aluvionais e das possibilidades eventuais de tratamento.

Sob o ponto de vista da composicão mineralógica dos diques pegntatíticos, Georges Soubotian descreve a presença de hornblenda verde escuro, em quantidade reduzida, associadla a grandes cristais de feldspato róseo. Êsse Autor, com base em estudos petrográficos dos granitos da área mineralizada, estuda o fenômeno da diferenciação magmática, com a formação de três tipos principais de granito - granito pegmatítico, granito a duas micas (biotita e muscovita) e granito biotítico de côr cinza escuro de estrutura porfiroide. De modo geral, tais conclusóes se aproximam das nossas. descritas acima, no capítulo das "Conclusões" $A$ diferenca reside apenas na extensão, bem maior, das áreas por nós estudadas.

Trata a seguir dos pegmatitos turmaliniferos e feldspáticos e faz consideraçós sobre o lipo de metamorfismo sofrido pelos xistos, sem, contudo, se deter no fenòmeno da turmalinizacão e greisconficação dos corpos mineralizados e rochas encaixanles. principais tópicos por nós abordados no estudo da mineralogênnse da faixa cstanifera. 
Com referência ao fenòmeno da mineralização, Soubotian considera dois grupos de fatos:

a) mineralização devida ao metamorfismo de contacto entre as rochas igneas e os xistos preexistentes e

b) mineralização devida à extração magmática e à ação hidrotermal e pneumatolitica em consequiência de intrusões dos diques pegmatíticos e quartzosos.

Estudou, principalmente, os depósitos aluvionais do Bio Camaquan e sangas circunvizinhas, descrevendo, além da cassiterita e estanita (minerais de estanho), a presenca de torita, volframita, almandina, grossularia, zirconita, ilmenita, monazita, ilmeno-rutílio, atanassa, platnerita, hematita e magnetita.

Finalmente, conclue que a mineralização é fraca, sendo mínima a quantidade de cassiterita nos leitos do Rio Camaquan, o que contrasta com as conclusões de Anatol Bromirsky que fixára, em mil toneladas, a quantidade de cassiterita no Aluvião Camaquan.

\section{Summary and Conclusions}

In Rio Grande do Sul, the southmost State of Rrazil, the southern part of the Encruzilhada district, and the northern part of the Piratini district consist predominantly of schists, quartzites and large masses of granites. Rock types delineated in the altached map, include the Algonquian schists, quartzites, and granites (Porongos series), and Devonian (?) conglomerates, red sandstones, and arkoses (Camaquan series).

The purpose of this study was to come to a decision concerning the history of the region. its geological and petrographical features, the structural relationships between the dikes, the veins, and the contiguous country rock, and the paragenesis of the minerals within the granites and dikes. Special attention was given to the origin of the cassiterite cryslals.

The slightly alkaline granite which is intruded in the schists, shows a certain variation in chemical and mineralogical composition, exhibiting gradations and different types. This differentiation which took place when the greater part of the granite had solidified, was due to the highly siliceous solutions and vapours derived from the final stages of the consolidation of the granite itself, moving toward the outside along cracks and fissures. Here it was found that the most basic purtion of the intrusion arrived first, succeeded by others in the order of increasing acidity. The differentialed areas show, however, many points of transition from one to another:

1. a central core of a fine to medium-grained rock containing over 30 per cent biotite (the only fer- 
romagnesian mineral found), and essentially free foom volatile constituents. It is a biotite granite (or granitite)

2. an intermediate zone with predominating binary granite (with both white and dark mica).

3 . an aureole composed predominantly of a granite which is characterized by the great predominance of muscovite. Ilere biotite is relatively scarce. This part of the granite invasion was followed by intrusions of granite-aplites and pegmatites, and deep-seated high temperature quartz veins.

Finally, during the final consolidation of the magma, the fugitive constituents are set frce and, escaping through joint fissures and other fractures, transformed certain parts in the granite, into "greisen" (an aggregate of quartz, white mica, cassiterite, fluorite and tourmaline) By the action of the same constituents large areas of the schists and quartzites are converted into "schorl-rock" (quartz and tourmaline). The "greisen" occurs usually following the regional joint directions in the granite. In view of the existence of fluorite in the "greisen", it proves the presence of fluorine among the volatile constituents accountable for the change. Greisenization is not confined to the granites, but is also developed in the schists.

In tourmalinization both feldspar and biotite have been converted into "schorl-rock" by the action of boro-fluoric emanations.

Cassiterite, usually occurring in pegmatite dikes, and associated with dikes of quartz, in a completely confused manner (chaotic or erratic distribution) would naturally be interpreted as a mineral formed due to the action of magnatic fluids (mineralizers).

Cassiterite crystals commonly occur symmetrically united to form twin crystals. The twinning-plane is parallel to a face of the pyramid $\{101\}$. Repeated twins are rare. Reniform shapes were not found. The cassiterite individuals are as much as $10 \mathrm{~cm}$ long. In color, cassiterite is nearly black to dark brown; sometimes almost transparent. Stannite. nordenskiöldine, hulsite, and paigeite are absent.

\section{IBibliografia}

- 1. Alvim, P A. Algumas minas do Rio Grande do Sul: Min. e Met. 4, 7-14, Rio de Janeiro (1939).

2. Barbosa, $O$. - Jazidas e minerais metálicos no Rio (irande do sul: Min. Met. 4, 194-195, Rio de Janeiro (1939).

3. Bateman, A. H. - Economic mineral deposits: John Wiley \& Sons Inc., New York (1942), 545-551. 
4. Beger, $P$ J - Zinnerzpneumatolyse und verwandte Erscheinungen im Kontakthofe des Lauzitzer Granits: Neues Jahrb. Min. $2,152-164$ (1914).

5 Beyschlag-Ḱrusch-Vogt - Die Lagerstätten der nutzbaren Mineralien und Gesteine: Verlag von Ferdinand Enke, Stuttgart, v 1, n. $3(1910), 409-443$.

6. Blaise, F. e Boutakoff, $\mathbf{N}$. - Note sur les differenciations de certains batholites granitiques du Kivu: Ann. Soc. Geo. Belgique, 93-100, (1940).

7 Bonney, T G. - On the microscopic structure of Luxullianite: Mineral. Mag. 1, 215-221, (1877)

8. Brammal, A. e Harwood, H. F _- Tourmalinization in the Dartmoor granite: Mineral. Mag. 20, 319-330, (1934).

9. Brögger, IV C. - Die Mineralien der Syenitpegmatitgänge der südnorwegischen Augite und Nephelinsyenite: Zeitschr für Krist und Min. 16, 226, (1890)

10 Carvalho, P F - Reconhecimento geológico no Estado do Rio Gran(le do Sul: S.G.M.B. Bol. 66, (1932)

11. Clarke, F W - The data of Geochemistry: Washington, Government Printing Oflice (1911), 417

12. de Lapparent, L. - Leçons de Petrographie: Masson et Cie. Éditeurs, Paris (1923), 149-166.

13 de Launav, L. - Gîtes mineraux et métallifères: Librairie Polytechnique Ch. Béranger, Éditeur; Paris et Liège. v. 2, (1913), 1-75.

14. Emmons, R. C. - The contribution of differential pressures to magmatic differentiation: Am. Jour Sci., 238, 1-21, (1940)

15. Emmons, W H. - The principles of economic geology: McGraw-Hill Book Company, Inc., New York and I.ondon (1940), 434-445.

16. Ghosh, P K. - The Bodmin Moor granite, Cornwall: Mineral. Mag 21, 285-309, (1927-1928)

17 Guimarães, D. - Volframita e cassiterita no municipio de Encruzilhada: S.G.M.B. Bol. 21, 65-70, Rio de Janeiro (1926)

18. Guimarães, D. - Quadro Crono-Geológico do Brasil: Min. e Met. 1. 65-71, Rio de Janeiro (1936)

19 Guimarães, D. - Contriliuição à metalogènese do maciço brasileiro: D.N.P.M. Bol. 16, 1-86, Rio de Janeiro (1937).

20. Guimarães, D. - A teoria da granitização progressiva: Min. e Met. 5, n. 27, Rio de Janeiro (1940)

21. Johannsen, A. - A Descriptive Petrography of the Igneous Rocks: The University of Chicago Press, Chicago, Illinois, v. 2, (1941), 151.

22. Landes, K. K. - The paragenesis of the granite pegmatites of Central Maine: Am. Mineral. 10, 355, (1925)

23. Leinz, V - Problemas geológicos do Post-arqueano no Estado do Rio Grande to Sul: Min. e Met. 4, 203-206, Rio de Janeiro (1939)

24. Leinz, V., Barbosa, A., Teixeira, E. A. - Mapa geológico CaçapavaI.avras: D.P.M. Bol. 90, 7-39, Porto Alegre (1941).

25. Leinz, V., Carneiro, S. A. - Gênese da jazida de cobre "Camaquan". Caçapava, Rio Grande do Sul: D.P.M. Bol. 88, 5-47, Porto Alegre (1941)

26. Leinz, V e Teixeira, E. A. - Ouro no Bloco Butiá, Rio Cirande do Sul: D.N.P.M. Bol. 50, 1-81, Rio de Janeiro (1942)

27 Lindgren, W - Mineral deposits: McGraw-Hill Book Company, Inc., New York and London (1933), 644-658. 
28. MeLaughlin, $T$ G. - Pegmatite dikes of the Bridger Mountains, Wyoming: Am. Mineral. 25, 46-68, (1940)

29. Oliveira, A. I. e Leonardos, Othon H. - Geologia do Brasil: Ministério da Agricultura, Rio de Janeiro (1943)

30. Ramdohr, P - Ein Zinnvorkommen bei Arandis, Deutsch-Südwestafrica: Neues Jahrb. Min. Beil. Bd. 70A, 1-48, (1935)

31 Schaller, W $\mathrm{T}$.- Mineral replacement in pegmatite: Am. Mineral. $12,59-63 .,(1927)$

32. Sederholm, J J. Uber die finlïndischen Rapakiwigesteine: Tscherm. Min. Petrog. Mitt. 12, 8, (1891).

33. Shand, W. T - Eruptive rocks: John Wiley \& Sons, Inc. New York (1943), 334-335.

34. Targa, F - Minas e minérios do Rio Grande do Sul: Rev Eso. Pol. Porto Alegre, 9, n. 3, (1924)

35. Teixeira, E. A. - Cobre no Rio Grande do Sul: D.N.P.M. Avulso 22. liio de Janeiro (1937)

36. Tolman, C. - Quartz dikes: Am. Mineral. 16, 278-299, (1931)

37 Uspensky, N. M. - Genesis of granitic pegmatites: Am. Mineral. $28,437-447,(1943)$

38. von Miklucho-Maclay, .I. - Rutil und Zinnstein im Greifensteiner Granit (Ehrenfriedersdorf): Neues Jahr Min. 2, 88-90, (1885) 


\section{Boletins publicados pelo Departamento de Mineralogia}

N. ${ }^{1}(1938):$

Saldanha, R. - Minerais da mina de Furnas: Cerussita. Minerais da mina de Furnas: Anglesita e Calamina.

Franco, R. R. - Sobre a baritina de Araxá.

N.c $2(1938)$ :

Onorato, E. - Pesquizas röntgenográficas sobre a leucita.

Saldanhä, R. -- Estudo morfológico e estatistico de São Miguel de Piracicaba.

Franco, R. R. -- Breve noticia sobre a hematita de Antônio Pereira.

N. ${ }^{\circ} 3(1939):$

Leonardos, O. II. e Saldanha, R. -- Diamante Darcy Vargas e outros grandes diamantes brasileiros.

Saldanha, R. - Sobre o euclásio de Dom Bosco, municipio de Ouro Preto.

Franco, R. R. - Breve noticia sobre a calcita de Botucatú.

Mathias, P _ Nota sobre a columbita de Figueira, Minas Gerais.

Patrima, J - Nota sobre um topázio de Arassuai, Minas Gerais.

N.o 4 (1941):

Leonardos, O. H. - Notas petrográficas sobre a série Ribeira.

Saldanha, R. - O diamante Coromandel

Saldanha, F. - Nota sobre o euclásio de Cachoeiro de Santa Leopoldina.

Franco, R. R. - Piromorfita em Araçariguama.

Wohlers, A. - Nota sobre o crisoberilo de Santa Tereza

N. ${ }^{\circ} 5(1942):$

Guimarães, D. -- Arrojadita. um novo mineral do grupo da wagnerita .

Saldanha, R. - O diamante Governador Valadares.

Camargo, W G. R. - Nota sobre a baritina de Serrote, S.P

Camargo, W G. R. -.. Nota sobre a calcita de Pedra do Sino, M. G. 
Este livro foi composto e impresso

nas oficinas de José Magalhães.

Rua Quirino de Andrade, 59-67

São Paulo 1944 

o Departamento de Mineralogia e Petrografia

pede e agradece a remessa de suas publicaçojes vous prie de lui envoyer vos publications. shall be glad to receive your publications. le agradecerá el envio de sus publicaciones.

\section{Endereço:}

o Deparlamento de Mineralogia e Petrografia Faculdade de Filosofia, Ciências e Letras Caixa Postal 105-B

S. Paulo (Brasil). 